University of Rhode Island

DigitalCommons@URI

Open Access Master's Theses

1993

\title{
A LAND USE PLAN FOR NOISE COMPATIBILITY NEAR QUONSET STATE AIRPORT NORTH KINGSTOWN, RHODE ISLAND
}

Katherine Raymond

University of Rhode Island

Follow this and additional works at: https://digitalcommons.uri.edu/theses

\section{Recommended Citation}

Raymond, Katherine, "A LAND USE PLAN FOR NOISE COMPATIBILITY NEAR QUONSET STATE AIRPORT NORTH KINGSTOWN, RHODE ISLAND" (1993). Open Access Master's Theses. Paper 568.

https://digitalcommons.uri.edu/theses/568

This Thesis is brought to you for free and open access by DigitalCommons@URI. It has been accepted for inclusion in Open Access Master's Theses by an authorized administrator of DigitalCommons@URI. For more information, please contact digitalcommons-group@uri.edu. 


\author{
A LAND USE PLAN \\ FOR NOISE COMPATIBILITY \\ NEAR QUONSET STATE AIRPORT \\ NORTH KINGSTOWN, RHODE ISLAND
}

BY

KATHERINE RAYMOND

A RESEARCH PROJECT SUBMITTED IN

PARTIAL FULFILLMENT OF THE REQUIREMENTS

FOR THE DEGREE OF MASTER OF

COMMUNITY PLANNING

UNIVERSITY OF RHODE ISLAND

1993 
MASTER OF COMMUNITY PLANNING

RESEARCH PROJECT

OF

KATHERINE RAYMOND

Found Prank

Approved: Major Professor Dr. Farhad Stash

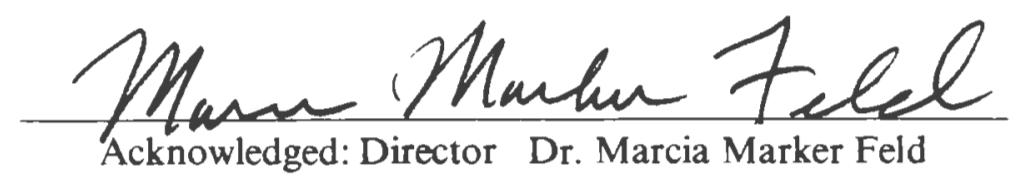




\begin{abstract}
This study is a land use plan for noise compatibility near Quonset State Airport. The study area includes northeastem North Kingstown and northern Jamestown. The premise of the study is that the future of Quonset State Airport (QSA) will include expanded military, cargo, and general aviation operations that will lead to a subsequent increase in noise in the surrounding community. Airport noise regulation is fragmented between federal, state, and local governments, and airport management. The current users of the airport already follow noise abatement procedures.

The Town of North Kingstown is diverse in its land use and economic base. Open space, industrial sites, and water lie immediately next to the airport. Jamestown is a more rural and residential community. Both Towns have residential areas in locations where they can be impacted by excessive noise. The redevelopment of the Quonset Point/Davisville industrial sites, the air traffic in Rhode Island, Massachusetts and Connecticut, and national defense policy will all have an impact on the future use of the airport. Because existing airport facilities can support large commercial aircraft, because of the other transportation links located in the complex, and because the airport is perceived as a low-impact noise area, Quonset Point/Davisville will become a target for future development.

By forecasting the number of daily jet operations through projected based aircraft of civilian and military tenants, the footprint of noise contours can be estimated using the Noise Exposure Forecast method. These contours are adjusted to reflect local flight patterns and then overlaid on land use and zoning maps. The overlays show residential land and undeveloped land that is zoned for residential use in areas that are not suitable for noise sensitive uses. As a preventive measure to a void more costly noise mitigation in the future, an Airport Overlay District is recommended for the area with certain residential zones within the district changed to non-residential. The study also makes recommendations on mitigation strategies and additional airport contributions to noise abatement.
\end{abstract}




\section{ACKNOWLEDGEMENT}

I am grateful to my readers,

David S. Winsor and Walter A. Slocomb,

for their critical and insightful comments;

and I especially want to thank Dr. Farhad Atash

for his assistance, patience, and encouragement. 


\section{TABLE OF CONTENTS}

Abstract .................................

Acknowledgement $\ldots \ldots \ldots \ldots \ldots \ldots \ldots \ldots \ldots \ldots \ldots \ldots$ ii

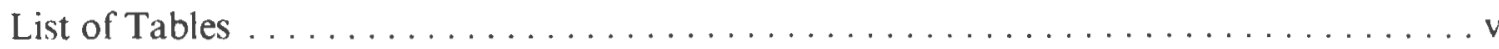

List of Figures $\ldots \ldots \ldots \ldots \ldots \ldots \ldots \ldots \ldots \ldots \ldots \ldots \ldots \ldots \ldots \ldots \ldots \ldots \ldots$

Chapter

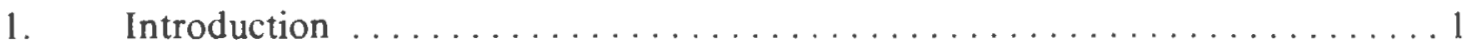

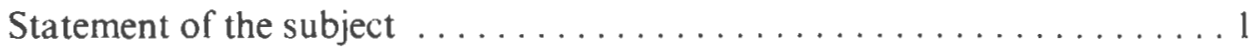

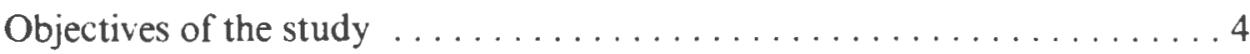

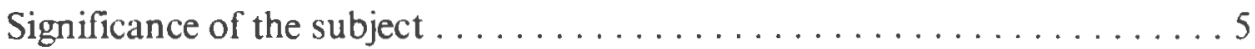

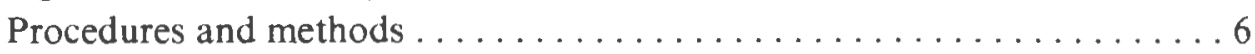

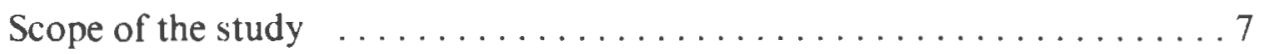

2. Airport Noise Regulation ....................... 10

The Federal Government . . . . . . . . . . . . . . . . . 10

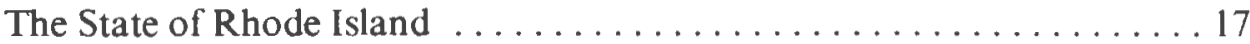

The Towns of North Kingstown and Jamestown ........... . 19

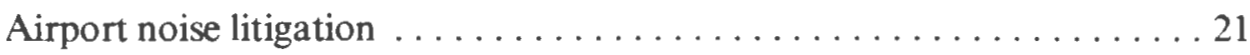

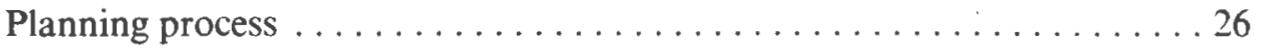

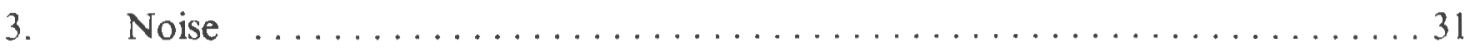

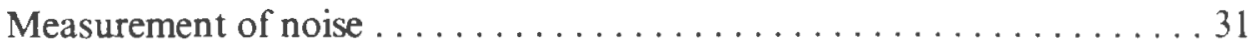

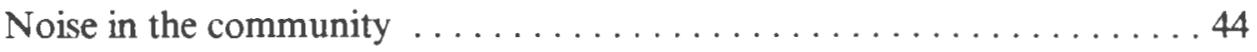

Noise mitigation techniques $\ldots \ldots \ldots \ldots \ldots \ldots \ldots \ldots \ldots . \ldots 49$

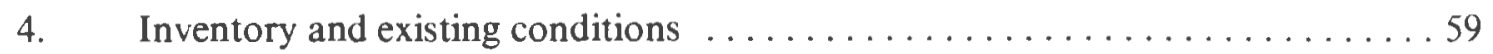

Quonset State Airport . . . . . . . . . . . . . . . . 59

Towns of North Kingstown and Jamestown . . . . . . . . . . 79

Noise contours and flight tracks $\ldots \ldots \ldots \ldots \ldots \ldots \ldots$ 
5. Forecasts . . . . . . . . . . . . . . . . . . . 96

Towns of North Kingstown and Jamestown . . . . . . . . . . 97

Quonset Point/Davisville ...................... . 103

Quonset State Airport ..................... 106

Noise contours .......................... 113

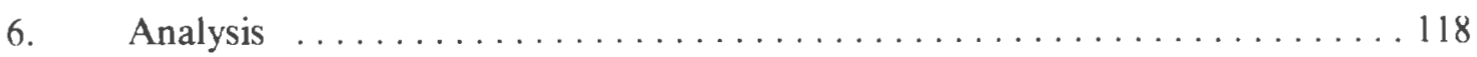

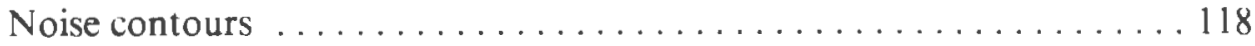

Impact of airport noise on the surrounding community $\ldots \ldots \ldots 120$

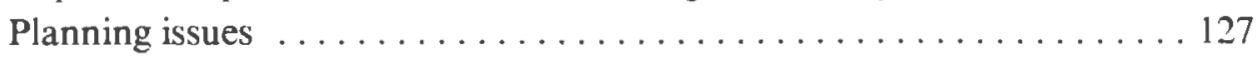

Evaluation criteria for noise abatement methods $\ldots \ldots \ldots \ldots \ldots 133$

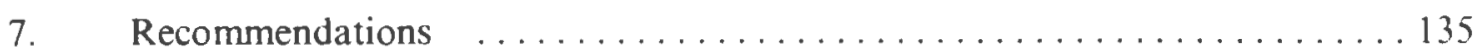

Phase I - Land use controls . . . . . . . . . . . . . . 135

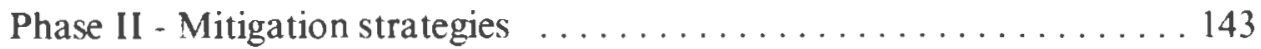

Quonset State Airport . . . . . . . . . . . . . . . . . 145

Conclusion and issues for further study $\ldots \ldots \ldots \ldots \ldots \ldots \ldots \ldots \ldots$

Appendix A. Land Use Guidance Chart for Land Use Sensitivity Interpolation . . . . . 149

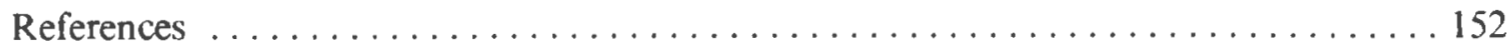




\section{LIST OF TABLES}

Table

page

2.1 Stage II and Stage III Aircraft Noise Limits $\ldots \ldots \ldots \ldots \ldots \ldots \ldots \ldots \ldots \ldots$

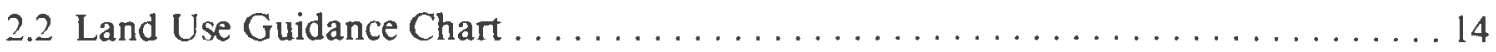

2.3 Permitted Sound Levels by Receiving Land Use $\ldots \ldots \ldots \ldots \ldots \ldots \ldots \ldots$

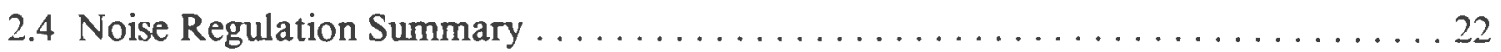

3.1 Adding Decibels: Two Sounds of Different Values $\ldots \ldots \ldots \ldots \ldots \ldots \ldots \ldots$

3.2 Adding Decibels: Many Sounds of the Same Value $\ldots \ldots \ldots \ldots \ldots \ldots \ldots$

3.3 Distances for Approximate NEF Contours $\ldots \ldots \ldots \ldots \ldots \ldots \ldots \ldots \ldots \ldots$

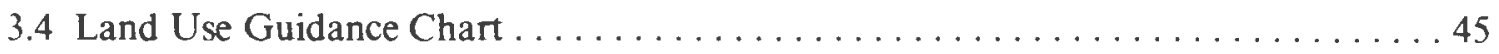

3.5 Acceptable Land Uses within Noise Zones . . . . . . . . . . . . . . 46

3.6 Qualitative Noise Descriptors Applicable to Residential Areas . . . . . . . . . . 48

4.1 Quonset State Airport, Annual Operations, $1980-1991 \ldots \ldots \ldots \ldots \ldots \ldots \ldots$

4.2 Quonset State Airport, Annual Passengers and Cargo, 1980-1991 . . . . . . . . . 73

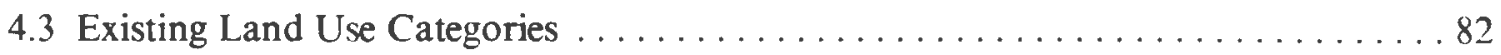

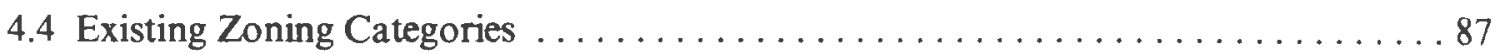

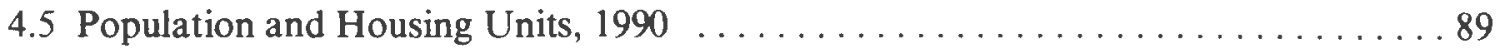

5.1 Population and Housing Units Forecast $\ldots \ldots \ldots \ldots \ldots \ldots \ldots \ldots \ldots \ldots \ldots \ldots \ldots \ldots$

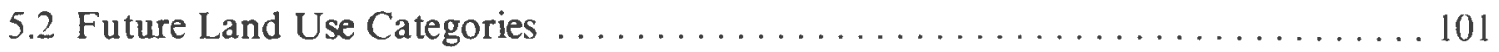

5.3 Quonset Point/Davisville Development Potential . . . . . . . . . . . . . . . . . . 104 
5.4 Future Operations of Jet Aircraft $\ldots \ldots \ldots \ldots \ldots \ldots \ldots \ldots \ldots \ldots \ldots \ldots \ldots \ldots$

5.5 Distances for Approximate NEF Contours $\ldots \ldots \ldots \ldots \ldots \ldots \ldots \ldots \ldots \ldots$

6.1 Land Use Guidance Chart . . . . . . . . . . . . . . . . . . . . . . . . . . . 124

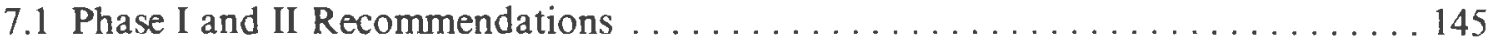




\section{LIST OF FIGURES}

Figure

page

3.1 Typical Sound Levels . . . . . . . . . . . . . . . . . . . . . 39

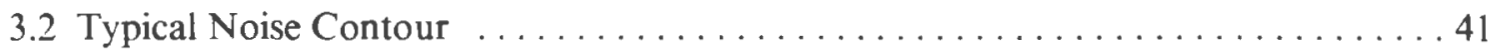

3.3 Noise Contour Using NEF Method of Approximation $\ldots \ldots \ldots \ldots \ldots \ldots \ldots \ldots$

4.1 Aerial Photograph of Quonset State Airport $\ldots \ldots \ldots \ldots \ldots \ldots \ldots \ldots \ldots \ldots \ldots$

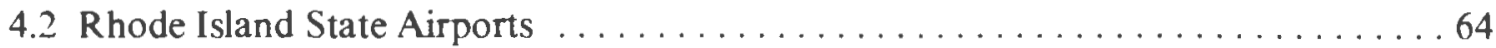

4.3 Quonset State Airport Layout Plan $\ldots \ldots \ldots \ldots \ldots \ldots \ldots \ldots \ldots \ldots \ldots \ldots \ldots \ldots \ldots \ldots$

4.4 Quonset State Airport, Annual Operations, $1980-1991 \ldots \ldots \ldots \ldots \ldots \ldots \ldots$

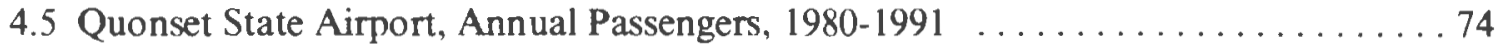

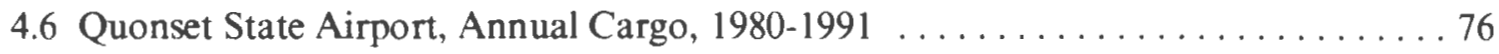

4.7 North Kingstown "No-Fly" Areas $\ldots \ldots \ldots \ldots \ldots \ldots \ldots \ldots \ldots \ldots \ldots$

4.8 North Kingstown Planning Districts $\ldots \ldots \ldots \ldots \ldots \ldots \ldots \ldots \ldots \ldots \ldots \ldots \ldots \ldots \ldots$

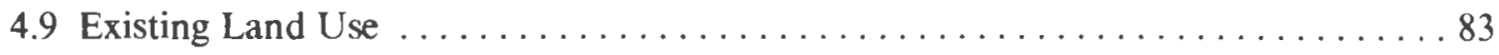

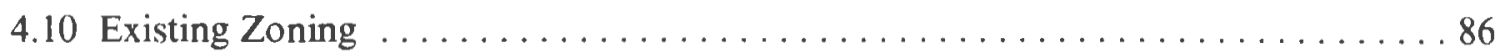

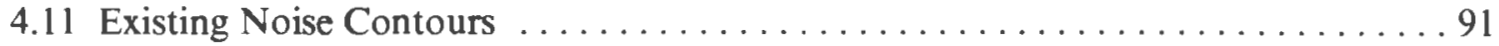

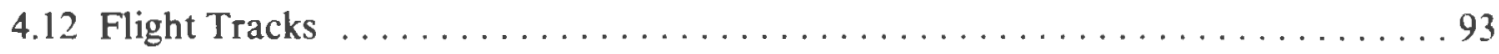

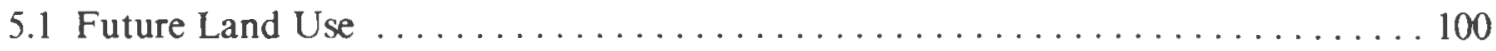

5.2 Quonset Point/Davisville Development Areas and Property Jurisdiction . . . . . . 105

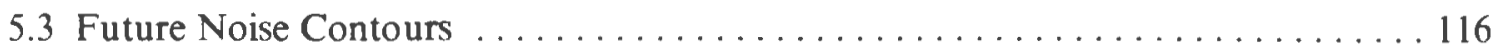

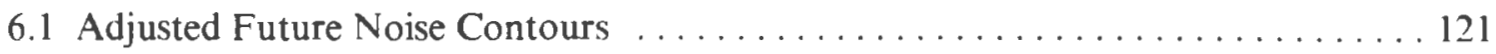


Figure

6.2 Existing Land Use and Noise Contour Overlay

6.3 Future Land Use and Noise Contour Overlay $\ldots \ldots \ldots \ldots \ldots \ldots \ldots \ldots$

6.4 Existing Zoning and Noise Contour Overlay $\ldots \ldots \ldots \ldots \ldots \ldots \ldots \ldots \ldots \ldots \ldots$

7.1 Jamestown - Recommended Plat Notices . . . . . . . . . . . . 137

7.2 North Kingstown - Recommended Plat Notices . . . . . . . . . . . . 139

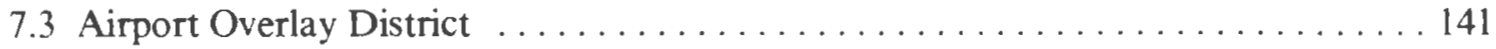




\section{CHAPTER ONE INTRODUCTION}

\section{Statement of Subject}

Airport noise is a problem that exists throughout the country, however, nobody denies the fact that major airports are necessary to satisfy economic and transportation needs. Noise abatement is a cause which is known to rally the communities surrounding airports. These grassroots organizations are successful in demanding certain restrictions which are intended to reduce noise. In general, airport management is interested in being a good neighbor.

Noise disputes arise because land use surrounding the airport is incompatible. This pattern of land use is exacerbated on both sides of the issue. Residential developments and suburban sprawl have crept into airport zones, while at the same time, airports have expanded to support increased aviation activity. In many states, such as New Jersey, small general aviation airports are being swallowed by residential development. In other states, such as Massachusetts, potential new airports are prevented from being built by neighbors concerned about noise even though Logan Airport in Boston is severely overcrowded.'

Aviation is an industry that is subject to international, federal, regional, state, and local regulations; it is a partnership between the public and private sectors; and it is also bound by environmental policies. It is a very complex enterprise, and that is reflected in the airport planning process. Each individual airport that receives federal funds is required by the Federal Aviation Administration (FAA) to have a master plan; Rhode Island produces a State Airport System Plan which is part of the FAA Continuous Airport System Planning Process. At the 
next level in the hierarchy, there is a National Plan of Integrated Airport Systems (NPIAS) that is produced by the FAA. The NPIAS is produced every ten years and projects future demand at airports and improvements that are eligible for federal funds. The inefficiency in this planning process is that the land surrounding each of these airports is in the jurisdiction of a municipality or other governmental entity, and incompatible land use is the result.

The State of Rhode Island is unique in the fact that all of the public airports are owned and operated by the state. There are six airports altogether, one primary and five general aviation airports. T.F. Green is the primary commercial airport in the state; Quonset, North Central, Newport, Westerly, and Block Island have different levels of use and play different roles with in the state system. Westerly and Block Island even have limited commercial service, but they are considered to be general aviation (GA) airports.

The subject of the study is a land use plan for noise compatibility at Quonset State Airport (QSA). T.F. Green is the most complex airport, but it has already been studied extensively. Quonset currently has a master plan with a section on noise that was completed in 1987, but there are no existing land use controls regarding noise abatement. Of the five GA airports, Quonset appears to be the most interesting and the most challenging. It has the longest runway in Rhode Island, has a higher utility rating than the other GA airports, ${ }^{2}$ and, other than T.F. Green, has the only other instrument landing system in the state. Two Rhode Island National Guard units are based at QSA.

It is no secret that the potential for the re-development of Quonset Point is unrealized, and its future is still undecided. However, Quonset is a unique facility in New England and an 
the east coast of the United States and can support a much greater amount of activity than it does now. Some unsubstantiated but reasonable expectations for growth include:

1) The Army National Guard is scheduled to update their fleet of helicopters and receive five new cargo planes in the future. The two National Guard units are not only surviving the base closures, they are likely to expand their operations.

2) Federal Express has maintained contact with the airport over the past few years and continues to express an interest in some level of cargo operations.

3) At least one new potential fixed-base operator, a small plane manufacturer, has expressed interest in establishing a business at Quonset.

4) As other airports in New England and T.F. Green continue to grow (the new terminal building is a good sign of projected growth), more general aviation may be forced out to Quonset or North Central.

These prospects together with the fact that there is limited overall airport capacity in the Northeast Corridor, lead me to believe that eventually, QSA will be a busy airport.

In a built-upcommunity such as Warwick, where T.F. Green is located, it is realistically too late to employ some planning techniques to mitigate noise, but it is not too late to do so in more rural communities like North Kingstown and Jamestown. If the town and airport can share responsibility for noise planning, and the airport can be established as a good neighbor, they can continue to co-exist and grow with minimal conflict.

There are several different methods of varying costs and degrees of effectiveness that can be used for noise mitigation. They are listed below, grouped by the responsible party and by the nature of the technique: 


\section{Airport management or administration}

Operational - airport operating hours, limits on aircraft maintenance testing, types of permitted aircraft, engine thrust level during landings and take-offs, and profile of landings and take-offs

Site improvements - On-site: site design, landscaping, and sound barriers

Off-site: soundproofing and building insulation

Municipality planning department

Land use planning - zoning, comprehensive planning, land acquisition, acoustic clustering, land banking, avigation or noise easements, purchase or transfer of development rights, plat map notices

Building code - more stringent building codes, noise disclosure by real estate agents

Industry and airlines (source reduction)

Development of new aircraft - quieter engines, short take-off and landing, and vertical take-off and landing aircraft

Modifying existing aircraft - retrofitting with noise reduction equipment (hushkits)

The project will be a land use planning study with specific recommendations for land use controls and noise mitigation in the short term and long term.

\section{Objectives of the Study}

The study has several objectives throughout the course of the project; these are:

1) To explore the history of noise regulation and the airport planning process;

2) To understand the scientific and technical nature of noise;

3) To develop a means of presenting the existing conditions of two very different towns, North Kingstown and Jamestown;

4) To assess current airport use and the impact of noise on the community;

5) To present expected future conditions of North Kingstown and Jamestown;

6) To predict future airport use and number of operations; 
7) To project the future impact of noise with respect to local flight patterns;

8) To analyze the impact of future noise on the community with existing land use controls in place;

9) To identify land at risk of incompatible development; and

10) To recommend land use controls that ensure compatible development in the future.

\section{Significance of the Subject}

The federal government supports noise reduction projects through the Airport Improvement Program which is administered by the FAA. Ten percent of all airport improvement monies are set aside specifically for noise abatement. To qualify for these funds, airports must have a comprehensive noise compatibility plan prepared with public input and approved by the FAA. A noise plan is therefore necessary to satisfy community goals and the federal government, and to receive noise abatement funds.

Quonset State Airport is the best-equipped of the five GA airports to relieve any traffic other than general aviation from T.F. Green. Quonset has the only other control tower and instrument landing system, and the longest runway in the state. In the event that Green becomes over-crowded, Quonset is the only airport that can accommodate large commercial aircraft.

This plan will be prepared with the assumption that the most likely future use of QSA will be a cargo, military, and general aviation airport in an ind ustrial park setting. Commercial passenger service will remain at T.F. Green. It is important to realize that land use planning now will prevent a more fragmented and costly noise abatement program later. Restrictions 
on operating hours and types of aircraft are examples of rules that may reduce the capacity of the airport, impede future growth, and discourage businesses and fixed-base operators from locating at Quonset. These rules can not be used exclusively to control noise because the FAA maintains final authority on grounds of interference with interstate commerce.

Airports should be regarded as assets to the community. They can play a key role in its economic development by attracting industry and tourism. Quonset Point is a good example of industrial park development, but there are still many vacant and underutilized parcels. Airports and their surroundings need to be thoughtfully planned so that they can continue to provide air transportation service, be good neighbors, and be minimally disruptive to the environment. Further, to maintain the integrity of the airport system, noise programs should be conceived in cooperation with the municipality and with other state airports.

Twenty years ago, when the Navy occupied Quonset, the town was forced to tolerate high noise levels. At the present time, noise is not a top priority problem. However, airport space is at a premium on the national level, especially in the northeast. At some point in the future, it is safe to say that Quonset could once again become a busy airport. This is a rare opportunity and a second chance to implement preventive strategies for noise mitigation. Noise is the primary reason why communities oppose airports as neighbors. If measures are taken now, Quonset will become an attractive site for air transportation industry expansion.

\section{Procedures and Methods}

The first step is to collect data, review reports, and become familiar with policies and 
programs. I will investigate the extent to which noise abatement techniques are currently utilized and where formal noise complaints typically come from. In addition to some areas in North Kingstown. the island Town of Jamestown also is impacted by noise to some degree.

Land use and population forecasts for the towns will be assessed. The most important procedure that will be performed is an overlay of a noise contour map with zoning and land use maps. I will map the noise contours myself, using the Noise Exposure Forecast method of noise contour approximation that is used by the Federal Aviation Administration. This method requires the forecasting the number of daily jet operations at the airport. According to the literature, the shape of a noise contour is roughly parallel to the runway, but the width and length is impacted by the type of aircraft and the surface of the ground. From this overlay, I will identify non-compatible uses and undeveloped land that is zoned for an non-compatible use.

Using the impacted and at-risk locations, land use controls will be applied to the parcels in question to come up with an overall strategy for noise mitigation. The degree to which the land is developed, the sensitivity of the use to the noise, and the cost of the improvement are criteria that I will be using to generate recommendations. Airport land needs will also be considered. I will suggest modifications to the zoning ordinance and building code for the two towns.

\section{Scope of the Study}

The study area will include the northeastern portion of North Kingstown and the 
northern portion of Jamestown. Although a small potion of East Greenwich lies in the study area, it is not included in the study because that town is impacted by noise from T.F. Green also, and any noise mitigation strategy prepared for East Greenwich should be completed with respect to both airports.

Recommendations include land use controls and noise mitigation strategies applying to landowners. Airport and aircraft operating procedures can be modified only in conjunction with the FAA, and current airport noise policy already encompasses these techniques. Noise measuring are not used in the plotting of the noise contours, and time constraints preclude the solicitation of community participation. 


\section{Notes}

1. Fort Devens in Massachusetts is a military base and airfield scheduled for closure that is in an ideal location to serve as a second major airport in the Boston metropolitan area. Residents in the four surrounding communities have vehemently protested aviation reuse.

2. Utility rating is determined by the length of the runway and the size of aircraft that can be accommodated. 


\section{CHAPTER TWO \\ AIRPORT NOISE REGULATION}

Airport noise became a serious problem in the 1960's when the first generation of jet aircraft began to replace the piston-engine aircraft, and the air transportation industry blossomed.' Jet aircraft are faster, more fuel-efficient, and can be operated more costeffectively; unfortunately, they are also louder than most of the older planes. ${ }^{2}$ Noisier planes, coupled with an increase in the number of operations, has led to noise complaints at airports. In the past thirty years, the need for the regulation of noise has been publicized by people living near airports, and that need has been recognized by the air transportation industry and governing agencies. The results have been piecemeal and fragmented due to the multitude of agencies and rule-making authorities at all levels of government that have contributed to the existing "patchwork" state of noise regulation. This chapter highlights the most important rules, policies, and programs relating to noise abatement at the federal, state, and local levels of government. A history of litigation over airport noise follows, as well as a brief discussion of the hierarchy of airport planning.

\section{The Federal Government}

Aviation is under the jurisdiction of the federal government because it involves interstate travel and commerce. During the 1960 's, there were two federal agencies with authority over air travel, the Federal Aviation Administration(FAA) and the Civil Aeronautics Board (CAB). 
The FAA dealt with safety and technology issues. The CAB dealt with the regulation of routes and airlines. In 1968, Congress gave the authority to regulate noise to the FAA through amendments to the Federal Aviation Act of 1958 (P.L. 90-411), and instructed the agency to promulgate rules concerning the measurement and abatement of aircraft noise. Other federal agencies, such as the Environmental Protection Agency and the Department of Housing and Urban Development, have also been concerned with the noise problem, and have relevant rules and programs. This section is a brief discussion of the existing noise regulations at the federal level.

\section{Federal Aviation Administration}

The FAA produced Federal Aviation Regulations, Part 36 (14 CFR $\$ 21$ and §36) Noise Standards: Aircraft Type Certification, in 1969, more commonly known as FAR Part 36. These rules were made within the framework of technology, safety, and economy. It required that new types of aircraft must conform to new noise emission standards before they could be certificated; existing certificated aircraft were exempted. Noise was measured in effective perceived noise decibels (EPNdB, discussed in the following chapter). Measurements were taken at certain points along approach, sideline, and departure paths. Because these regulations were not retroactive, they did not apply to aircraft already in use, and therefore they had no immediate impact.

Several years later, new orders of older types of aircraft were still exempt from compliance. However, one change that was made in 1973 was the requirement for the new 
orders of older aircraft over 75,000 pounds to conform to FAR Part 36 . This applied only to largest wide-bodied jets, not the more frequently used medium and narrow-bodied jets.

Communities were dissatisfied with the results of federal noise rules because increasing airport use counteracted any reduction in noise emissions. Airports began to make their own rules and set curfews under pressure from the communities. At the same time airlines complained of too much federal regulation and non-standardized local regulations.

This dissatisfaction with the progress of current noise policy led to the Aviation Noise Abatement Policy of 1976 which had more stringent regulations; it mandated that the entire aircraft fleet conform to FAR Part 36 by 1985 after a timed phase-in period. All existing types that had been previously grandfathered were now required to be retired or retrofitted with "hush kits." This policy also expanded responsibilities for noise control beyond the federal government. Airport operators, state and local governments, and air carriers should all contribute to noise abatement.

The regulations of 1977 and 1978 modified and strengthened FAR Part 36. This act established three levels of noise, Stages I, II, and III. Stage I is a level of noise above the standards set in 1969. Stage II is the allowable level of noise established by FAR Part 36. Stage III is the new level of allowable noise set in 1977. These new standards varied by weight of the aircraft and by number of engines, and applied to all new certificate applications after 1975 . Table 2.1 is a comparison between Stage II and III noise levels. ${ }^{4}$ 
Table 2.1. Stage II and III Aircraft Noise Limits (measured in EPNdB).

\begin{tabular}{|c|c||c|c|c||}
\hline \multicolumn{1}{|c|}{ Measurement point } & Stage II & \multicolumn{3}{|c||}{ Stage III } \\
\cline { 2 - 5 } & $\begin{array}{c}\text { all } \\
\text { aircraft }\end{array}$ & $\begin{array}{c}4 \text { or more } \\
\text { cngincs }\end{array}$ & 3 engines & $\begin{array}{c}1 \text { or } 2 \\
\text { cngincs }\end{array}$ \\
\hline Takcoff - extended runway centerline & $93-108$ & $89-106$ & $89-104$ & $89-101$ \\
\hline Takeoff - side of runway & $102-108$ & $94-103$ & $94-103$ & $94-103$ \\
\hline Approach - extended runway centerline & $102-108$ & $98-105$ & $98-105$ & $98-105$ \\
\hline Approach - side of runway & $102-108$ & $94-103$ & $94-103$ & $94-103$ \\
\hline
\end{tabular}

Source: Harper, Transportation Journal, 1988, p. 37.

A pilot program established by FAA Order 5900.4 entitled Airport Noise Control and Land Use Compatibility (ANCLUC) under the Planning Grant Program provided these types of funds for the first time. To qualify for this program, the airport owner must be a sponsor or co-sponsor of a study in one of the following categories: noise control, land use compatibility, and coordination.

In 1977, the FAA published an Advisory Circular, titled "Airport Land Use Compatibility Planning." The Land Use Guidance Chart, shown in Table 2.2, is included in this publication and shows the basic relationships between noise exposure, noise descriptors, land use guidance, and noise control. Levels of noise are expressed in four different measurement scales. Corresponding to each level is a Land Use Guidance (LUG) Zone. The LUG zone is rated by noise exposure, e.g. moderate or severe, and is deemed acceptable for certain uses. The land uses and measurement scales will be discussed in Chapter Three. The Department of Housing and Urban Development (HUD) has developed its own guidelines applying to funded 
housing projects falling within certain zones. Suggested noise controls are given for the LUG zones.

Table 2.2 Land Use Guidance Chart

\begin{tabular}{|c|c|c|c|c|c|c|c|}
\hline \multirow{2}{*}{$\begin{array}{l}\text { Land use } \\
\text { guidance } \\
\text { tones }\end{array}$} & \multirow{2}{*}{$\begin{array}{l}\text { Noise } \\
\text { exposure } \\
\text { class }\end{array}$} & \multicolumn{4}{|c|}{ Aircraft noise estimating methodologies } & \multirow{2}{*}{$\begin{array}{l}\text { HID noise } \\
\text { assessment } \\
\text { guidelines }\end{array}$} & \multirow{2}{*}{$\begin{array}{l}\text { Suggested noise } \\
\text { controls }\end{array}$} \\
\hline & & $\mathrm{L}_{\mathrm{dn}}$ & NEF & CNR & CNEL & & \\
\hline A & minimal & $\begin{array}{l}0 \\
\text { to } \\
55\end{array}$ & $\begin{array}{l}0 \\
\text { to } \\
20\end{array}$ & $\begin{array}{l}0 \\
\text { to } \\
90\end{array}$ & $\begin{array}{l}0 \\
10 \\
55\end{array}$ & $\begin{array}{l}\text { clearly } \\
\text { acceptable }\end{array}$ & $\begin{array}{l}\text { normally requires no } \\
\text { special considerations }\end{array}$ \\
\hline B & moderate & $\begin{array}{l}55 \\
\text { to } \\
65\end{array}$ & $\begin{array}{l}20 \\
10 \\
30\end{array}$ & $\begin{array}{l}90 \\
\text { to } \\
100\end{array}$ & $\begin{array}{l}55 \\
10 \\
65\end{array}$ & $\begin{array}{l}\text { normally } \\
\text { acceptable }\end{array}$ & $\begin{array}{l}\text { land use controls } \\
\text { should be considered }\end{array}$ \\
\hline$C$ & significant & $\begin{array}{l}65 \\
10 \\
75\end{array}$ & $\begin{array}{l}30 \\
\text { to } \\
10\end{array}$ & $\begin{array}{l}100 \\
\text { to } \\
115\end{array}$ & $\begin{array}{l}65 \\
10 \\
75\end{array}$ & $\begin{array}{l}\text { normally } \\
\text { unacoptable }\end{array}$ & $\begin{array}{l}\text { land usc, cascments. } \\
\text { and other controls } \\
\text { rwommendal }\end{array}$ \\
\hline 1) & severe & $\begin{array}{l}75 \\
\text { and } \\
\text { over }\end{array}$ & $\begin{array}{l}40 \\
\text { and } \\
\text { over }\end{array}$ & $\begin{array}{l}115 \\
\text { and } \\
\text { over }\end{array}$ & $\begin{array}{l}75 \\
\text { and } \\
\text { over }\end{array}$ & $\begin{array}{c}\text { clearly } \\
\text { unacreptable }\end{array}$ & $\begin{array}{l}\text { contain within airport } \\
\text { boundary or positive } \\
\text { controls recommended }\end{array}$ \\
\hline
\end{tabular}

Source: Federal Aviation Administration, Advisory ('ircular 150/5050-6, 1977.

The Aviation Safety and Noise Abatement Act of 1979 (P.L. 96-193) was passed by Congress with mixed results. One of the negative effects of the legislation was to relax some of the mandates for aircraft to comply with noise standards. For instance, two-engine aircraft deadlines were extended in consideration of placing small communities at a disadvantage, and other deadlines were extended if airlines had firm commitments for new orders or hush kits. ${ }^{6}$ By 1985,80 percent of the aircraft complied with Stage II noise levels; 10 percent were Stage I aircraft, and the remaining 10 percent were Stage III.

Federal Aviation Regulations Part 150 (14 CFR §150) was a productive result of the 
Aviation Safety and Noise Abatement Act. FAR Part 150 was designed to implement some of the provisions of the Act. It established a single system for measuring noise and determining levels of noise exposure. It also formalized the experimental ANCLUC Planning Grant Program of 1977 into the standardized Noise Compatibility Planning Program. The program requires public participation and includes:

1) provision for the development and submission to the FAA of Noise Exposure Maps and Noise Compatibility Planning Programs by airport operators;

2) standard noise units, methods and analytic techniques for use in airport assessments;

3) identification of land uses that are normally compatible (or noncompatible) with various levels of noise around the airport; and

4) procedures and criteria for FAA approval or disapproval of noise compatibility programs by the Administrator.

It is through the Noise Compatibility Planning Program that airports become eligible for federal funds. These monies are a dedicated portion of Airport Improvement Program (AIP) funds. The AIP was established by the Airport and Airway Improvement Act of 1982 (P.L. 97-248) and provides funds for projects such as runway construction, land acqisition, and navigation equipment. This act set up a trust fund, 10 percent of which is reserved for noise compatibility planning and implementation. ${ }^{8}$ In 1991, S180 million was spent by the FAA in this category. Projects are funded at 90 percent of the total cost; the remaining 10 percent is provided by the airport." Quonset State Airport may be eligible for federal funds through this 
program.

In the late 1980's and early 1990's there was a movement at the national level to phase out Stage II aircraft and implement standards for Stage IV aircraft; ${ }^{10}$ the result of this movement was the Aircraft Noise and Capacity Act of 1990 (49 U.S.C. 2153-2156). The act requires the establishment of a national noise policy, including a ban on Stage II aircraft greater than 75,000 pounds." At the current time, Stage I aircraft are banned from operation in the U.S., and hush kits are available to retrofit Stage II aircraft to meet Stage III standards.

\section{Environmental Protection Agency}

Legislation that has an indirect impact on airports is the National Environmental Policy Act (NEPA) of 1969 (P.L. 91-190). NEPA requires that all federal agencies assess and disclose significant potential impacts of any construction project on the natural and human environment via an Environmental Impact Statement (EIS). Noise is one of many criteria that must be

evaluated. $^{12}$ In 1972, the Environmental Protection Agency (EPA) became more directly involved in noise regulation, but only in an advisory capacity to the FAA. The Noise Control Act of 1972 (P.L. 92-574) allowed the EPA to prescribe noise standards, but the legislation had little impact because the FAA could veto any recommendations based on safety, technological, or economical feasibility.

\section{Department of Housing and Urban Development}

HUD has responded to the airport noise problem from the point of view of impacted 
residents with Advisory Circular 1390.2, "Noise Abatement and Control: Departmental Policy, Implementation Responsibilities, and Standards," published in 1971. Standards have been developed that designate zones near airports as clearly acceptable, normally acceptable, normally unacceptable, or unacceptable for federally assisted or insured housing. This standard has been effective in determining the location of such housing. ${ }^{13}$

\section{Department of Defense}

Although military aircraft are exempt from FAA noise standards, they participate in noise reduction efforts. The Air Installation Compatible Use Zone was defined and established in 1973 for the purpose of mitigating noise impacts of a military base on the surrounding properties and minimize land use conflicts. ${ }^{14}$ This program defines Compatible Use Zones within noise contours that are similar to the FAA's LUG zones. The military also voluntarily uses aircraft operation procedures that reduce noise. The National Guard Noise Abatement program is an example of their involvement. This program will be described in Chapter Five as it applies to Quonset State Airport.

\section{The State of Rhode Island}

The State of Rhode Island is unique in that all of the public airports are owned and operated by the state. Most public airports in other states are owned by a municipality, county or region, or airport authority. Prior to 1993, the Rhode Island Department of Transportation, Division of Airports was the primary administrating agency; currently, this function is being 
transferred to the Airport Corporation within the Rhode island Port Authority. The six state airports (T.F. Green, Quonset, North Central, Newport, Westerly, and Block Island) are supported by a combination of federal and state funds and airport revenue. The State, however, does little to regulate airport noise; for the most part it relies on federal standards. The State is at somewhat of a disadvantage in the regulation arena in that it does not own, nor does it have any jurisdiction over the land surrounding airports which bears the impact of the noise problem.

Due to the fact that Rhode Island one primary airport and five GA airports, T.F. Green receives the most state and federal money. There are no existing funding sources at the state level that are available for noise abatement at general aviation airports. ${ }^{15}$

Title I: Aeronautics of the Rhode Island General Laws (R.I.G.L.) governs the administration of airports. Four chapters comprise Title I:

Chapter One: Airports Division

Chapter Two: Airports and Landing Fields

Chapter Three: Airport Zoning

Chapter Four: Uniform Aeronautical Regulatory Act

Chapter Two addresses the noise issue directly in two sections. Leases, concessions, and licenses (Section 7), requires aircraft using T.F. Green State Airport to meet FAR Part 36 noise emissions standards by January 1, 1989. This section also endorses the development of a landing fee schedule that encourages aircraft operations between the hours of $6: 30$ a.m. and midnight, to minimize the intensified impact of night time noise. Noise and emmission directives (Section 16), is even more explicit. It directs pilots using T.F. Green to "minimize the use of 
reverse engine thrust employed to slow an aircraft as it lands," to the greatest extent possible without compromising safety. ${ }^{16}$

Chapter Three, Airport Zoning, is of interest. This law grants municipalities the authority to zone land around the airport in a way that protects airport approach and hazard areas. The primary concern is to limit the height of structures and trees. Section 5 specically mentions the authority to specify permitted land uses, but it does not state any particular reason except to control the height of objects in hazard areas.

It is state policy to encourage and support military activities at state airports. ${ }^{17}$ There economic benefits to having military facilities, but there are environmental consequences as well, noise being only one of them. This, coupled with the fact that the existing state noise regulations apply only to Green, makes the area surrounding QSA particularly vulnerable to noise problems.

\section{The Towns of North Kingstown and Jamestown}

Quonset State Airport lies entirely within the Town of North Kingstown; however, residents of the northern portion of the island community of Jamestown are impacted by noise generated at QSA. Because the airport is state-owned, the towns have little opportunity to regulate noise.

\section{Town of North Kingstown}

The Town of North Kingstown supports future development of Quonset airport for 
economic reasons. The airport is used as an asset to market industrial sites. Noise was a problem when Quonset was a naval air station; however, at the current level of use, noise is not perceived to be a major problem. If and when the airport is ever used to its fullest potential, noise will most definitely be a consideration. North Kingstown has a Noise Ordinance which reflects the concern for a quiet environment. The Revised Ordinances Sections 8-81 through 8-99 are devoted to the issue of noise.

It is the declared policy of this town to promote an environment free from excessive noise or otherwise properly called "noise pollution." which unnecessarily jeopardizes the health and welfare and degrades the quality of lives of the residents of this community, without unduly prohibiting, limiting or otherwise regulating the function of certain noise-producing equipment which is not amenable to such controls yet is essential to the economy and quality of life of the community. Sec. 8-81(5).

The ordinance also explicitly exempts military operations and the airport from compliance in Section 8-85(6). The following table describing permitted noise levels within different zones is from the ordinance Section 8-87(a).

Table 2.3 Permitted Sound Levels by Receiving Land Use

\begin{tabular}{|c|c|c|}
\hline Zoning category of receiving land use & Time & Sound level limit, dBA \\
\hline \hline Residential and open space & 8 a.m. to 10 p.m. & 60 \\
\cline { 2 - 4 } & 10 p.m. to 7 a.m. & 50 \\
\hline Business (neighborhood, waterfront, general) & At all times & 65 \\
\hline Business (heavy, planned and industrial) & At all times & 70 \\
\hline Noise sensitive area & At all times & 60 \\
\hline
\end{tabular}

Source: North Kingstown Revised Ordinances Section 8-87(a), 1992, p. 627.

Note: Noise sensitive area is not defined. Residential zones appear to be mistakenly unaccounted for between the hours of 7 a.m. and 8 a.m. 
This ordinance makes it clear that a quiet community is desirable, but that it also not in the jurisdiction of the town to regulate airport noise. It also is clear that the town does not intend to over-regulate, nor to discourage or inhibit necessary economic activities.

\section{Town of Jamestown}

The Town of Jamestown does not have a noise ordinance like North Kingstown does; however, the Town Zoning Ordinance addresses airports. Airports are not a permitted use on the island, presumably because of the potential for noise. The Quonset control tower has reported that there have been sporadic complaints of airplane noise from Jamestown. The Town has expressed an interest in being informed of future development at Quonset State Airport.

To summarize the preceding sections on laws governing noise, Table 2.4, Noise Regulation Summary, is a matrix containing the administrative agencies, policies, plans, and programs at three levels of government and at Quonset State Airport. Policies at QSA will be discussed in detail in Chapter Five.

\section{Airport Noise Litigation}

There are numerous cases involving airport noise regulation, some of which have gone all the way up to the Supreme Court of the United States. For the purposes of this study, they are separated into two categories: 1) cases over the legality of specific airport rules, usually initiated by airlines; and 2) cases of recovery of damages from airport noise, usually initiated 
Table 2.4 Noise Regulation Summary

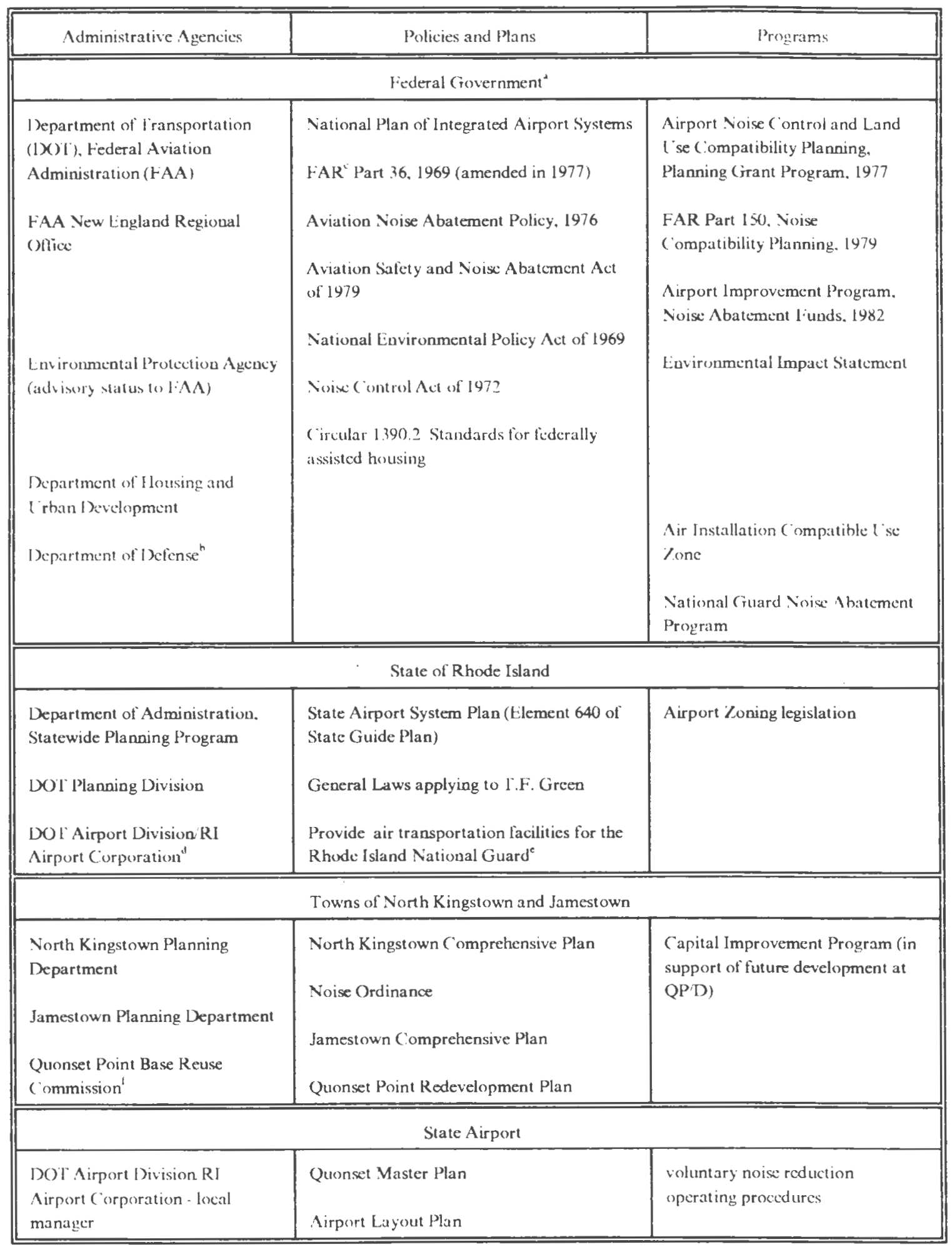


Notes:

a. The federal government is also bound by global standards set by the International Civil Aviation Organization. The ICAO sets aircraft noise standards which are virtually the same as FAR Part 36 mandates.

b. Military aircraft are cxempt from federal noise standards. but participate in noise reduction cfforts.

c. Federal Aviation Regulations.

d. At the time of this writing, the Airport Corporation was in the process of being defined. It is a division of the RI Port Authority which is headed by the director of the State Department of Economic Development. If implemented fully, some or most of the duties of the Division of Airports would shift to the Airport Corporation.

e. Rhode Island Statewide Planning Program, State airport system plan, Report Number 47. State Guide Plan Element 640, (1984): 7.1

1. North Kingstown Town officials are members of the hase re-use commission that supervises the production of the Redevelopment Plan.

by private citizens. This is not a comprehensive analysis of airport litigation, but rather a brief summary of applicable and relevant legal theories.

\section{Airport Rules}

Airport rules restricting types of aircraft and hours of operation can be found to be illegal if they are in violation of one or more of three constitutional clauses: the Supremacy Clause, the Interstate Commerce Clause, and the Equal Protection Clause.

\section{Supremacy Clause. The Supremacy Clause (U.S. Constitution, Article VI, Section 2)}

provides that state and local authorities do not possess the power to legislate inconsistently in matters subject to comprehensive federal law. This concept is also known as federal preemption. In City of Burbank v. Lockheed Air Terminal, Inc. 411 U.S. 624 (1973), the Supreme Court found a noise regulation invalid based on this concept. The city had placed a 
curfew on airport operations through its police power. The private owners of the airport argued that the restriction undermined federal authority. The Court found that if the curfew was upheld, and other communities enacted similar laws, the FAA's ability to control air traffic would be impaired. The decision was carefully written so as not to invalidate all noise restrictions.

Interstate Commerce Clause. (U.S. Const., Art. I, Sec. 5) Restrictions that are overly burdensome can be found to have a negative impact on commerce; however, this argument has not been very successful in court. In National Aviation v. City of Hayward 418 F. Supp. 417 (N.D. Cal. 1976), the U.S. District Court decided that a ban on all aircraft operations between 11 p.m. and 7 a.m. was legal. The rule was a means to effect a legitimate public interest, and although there was an impact on interstate commerce, it was only incidental. ${ }^{18}$ This seems to be in direct conflict with Burbank. The reason for this contradiction is related to the authority or agency who makes the rule. Rules made by the airport proprietor are more likely to be upheld than the outside exercise of police power. ${ }^{19}$

Another case which demonstrates this principle is Arrow Air, Inc. v. Port Authority of New York and New Jersey 602 F. Supp. 314 (S.D.N.Y. 1985). The rule in question was the ban on all Stage I aircraft. The plaintiff argued that the rule would impose a burden on commerce and force a change in the airline's market. The Court found again that the burden was incidental, and the Clause was meant to protect the market, not an individual company. ${ }^{2 n}$

Equal Protection. (U.S. Const., Amendment 14, Sec. 12) This clause can be satisfied if restrictions are fair, reasonable, and non-discriminatory. In Santa Monica Airport 
Association v. City of Santa Monica48I F. 2 d supp. 927 (D.D. Cal. 1979), five regulations were challenged under this premise. All but one were found to be legitimate; a total ban on jet aircraft was struck down because other types of aircraft made as much noise as the jets. The rule discriminated unfairly against the type of aircraft and did not reasonably effect the objective of noise reduction. ${ }^{21}$

\section{Damage Recovery}

These cases are brought on by landowners near airports who feel as if the noise from the airport has caused them damage, and they sue to recover damages. There are three legal theories that have been used, trespass, nuisance, and inverse condemnation; the latter has been the most successful approach.

Trespass. Plaintiffs who have used this cause of action are under the assumption that they own the air rights above their property. The Air Commerce Act of 1926 (P.L. 64-254) declares that the federal government has "compete and and exclusive national sovereignty in the airspace over the entire country." Navigable airspace is the minimum safe flying altitude defined by the FAA. Trespass is difficult to prove unless the property lies directly under the flight path, and aircraft dip below safe levels. ${ }^{22}$

Nuisance. This theory has also been used unsuccessfully because aviation is a publicly sponsored activity and necessary to the economy. The public interest usually outweighs the damage done to the individual. The case of Greater Westchester Homeowners Association v: City of Los Angeles 603 P. 2d 1329 (Cal. 1979), cert, denied, 449 U.S. 820 (1980), however 
stated that sanctioning an activity does not guarantee a sanction to creating a nuisance. Although aviation is a federally sponsored activity, the court found a nuisance in the airport's noise, smoke, and vibrations. The airport has the responsibility to acquire adequate noise easements. 23

Inverse condemnation. In one of the most important cases in aviation, the plaintiff argued that the presence of the airport had devalued his land and interfered with its use. Therefore, it was a taking of private property for public purposes without just compensation. The U.S. Supreme Court in Griggs v. County of Allegheny 369 U.S. 84 (1962) decided not only that the noise from aircraft passing thirty feet above the property caused a loss in property value, but that the local airport proprietor was liable for damages, not the airlines, manufacturers, or the federal government. This places the bulk of the burden of noise abatement on airport owners, because they in fact decided where to build the airport. It is for this reason that the FAA is reluctant to promulgate stricter noise standards; they do not want to become liable for cases of inverse condemnation. ${ }^{24}$

Lawsuits against airports on grounds of damage caused by noise as well as lawsuits by the air transportation industry for excessive noise regulation are very real risks for an airport owner. That is why a comprehensive noise abatement program that spreads the responsibility of noise control over the different levels of government and the industry is important.

\section{Planning Process}

There are three levels in the airport planning hierarchy, individual airport, state system, 
and national system. Each level will be described briefly as it relates to noise compatibility planning. Noise planning should be a fundamental element of state and airport plans, even in airports where noise is not considered a major problem. Within the space of a few years, residential developement can creep closer to the airfield while airport use is increasing; this seemingly unanticipated growth can be planned for at the local level through coordination with municipalities.

The National Plan of Integrated Airport Systems (NPIAS) is produced every ten years by the FAA as required by the Airport and Airway Improvement Act of 1982. The NPIAS is a summary of all airports in the country by state which are considered to be important to the inational airspace system. The plan does not go into any detail regarding noise compatibility planning except to give a brief description of FAR Part 150 and encourage airports to participate. Between 1982 and 1989, \$728 million was spent by the federal government on Noise Compatibility Grants. Of the total, 70 percent was allocated for land acquisition and relocation, 19 percent for soundproofing buildings, 3 percent for planning, and 8 percent for other items. ${ }^{25}$ Three of the seven policy recommendations outlined in the NPIAS are concerned with noise:

- Increased incentives for compatible use around airports

- Continued research toward quieter aircraft

- Continued measures to accelerate the retirement of Stage II aircraft ${ }^{26}$

State airport system plans should be updated every five years; however, the most recent Rhode Island plan is dated 1984. Noise is recognized as a major issue only at T.F. Green 
Airport, and that is an accurate assessment. This plan recommends the noise abatement measures that came out of the Noise Compatibility Study completed for that airport. Noise control efforts are likely to be supported by the state as one of the objectives of the airport system is "operation in a manner that is environmentally acceptable and that is as compatible as possible with the surrounding community." ${ }^{27}$ More attention should be given to the possibility of future noise at GA airports.

Normally, airport master plans are produced by the Department of Transportation Division of Planning; however, the most recent master plan for Quonset was prepared by Statewide Planning in 1987. The Quonset State Airport Master Plan is very thorough and provides an in-depth discussion of noise in the chapter on Environmental Factors. A noise study was conducted by a consultant, and the plan is useful for site specific technical data, but actual recommendations are sparse because it was found that noise was not a very significant problem. Existing noise abatement measures will be discussed in Chapter Four. 


\section{Notes}

1. Donald V. Harper, Regulation of aircraft noise at major airports: Past, present, and future, Transportation Law Journal 17, 1 (1988): 119.

2. CLM/Systems, Inc., Airports and their environment: A guide to environmental planning. Prepared for U.S. Department of Transportation, Office of the Secretary, Office of the Assistant Secretary for Environment and Urban Systems, (1972): 78.

3. Donald V. Harper, The continuing dilemma of aircraft noise, Transportation Journal 28 , 2(Winter 1988): 34 .

4. A technical discussion of noise perception and measurement follows in Chapter Three.

5. Bolt Beranek and Newman, Inc., Noise control plan development, Seminar notes, prepared for U.S. Department of Transportation, Federal Aviation Administration (1979): 44.

6. Ibid.

7. U.S. Department of Transportation, Federal Aviation Administration, Noise control and compatibility planning for airports, Advisory Circular 150/5020-1 (1984): i.

8. U.S. Department of Transportation, Federal Aviation Administration, National plan of integrated airport systems 1990-1999, (Washington, D.C., 1991): 8.

9. U.S. Department of Transportation, Federal Aviation Administration, Southern Region, Airport improvement program (1991).

10. Norman Ashford and Paul H. Wright, Airport engineering, 3rd ed., (New York: John Wiley and Sons, Inc., 1992): 91.

11. National plan of integrated airport systems, 18.

12. U.S. Department of Transportation, Federal Aviation Administration, Southern Region, Airports Division. Public's guide to federal en vironmental requirements and responsibilities.

13. Bolt Beranek and Newman, Noise control plan development, 48.

14. Ibid. 
15. Rhode Island Statewide Planning Program, State airport system plan, Report Number 47, State Guide Plan Element 640 (1984): 6.49.

16. Rhode Island, Rhode Island general law's, Title I, Aeronautics (1956 as amended through 1992), Chapters 2 and 3.

17. State airport system plan, 7.1 .

18. Gail Schlesinger, Airport noise: The proprieter's dilemma, Transportation Law Journall6, 2 (1988): 236.

19. Ibid., 235 .

20. Ibid., 237.

21. Ibid., 238.

22. Harper, Transportation Law Journal, 128.

23. Ibid.

24. Ibid., 130 .

25. National plan of integrated airport systems, 18.

26. Ibid., vii.

27. State airport system plan, 7.1 . 


\section{CHAPTER THREE NOISE}

Noise is defined as unwanted so und. In the context of planning, noise is a phenomenon that can adversely impact the quality of life in a community. The first part of this chapter is a discussion of what noise is, what the characteristics of aircraft noise are, and how airport noise is measured. With this basic understanding of what noise is, this chapter explores the issues of land use sensitivity and community reaction to noise. In addition this chapter outlines various noise abatement techniques.

\section{Measurement of Noise}

Different noises have different characteristics that make them more or less annoying than other noises. The cumulative effect of several noises together is discussed to obtain a more realistic understanding of the noise environment. Noise measurement techniques have been adapted to account for different characteristics of noise and to more accurately reflect how people perceive them. Noise contours are a graphic representation of sound levels generated from a single source, such as an airport.

\section{The Nature of Noise}

Sound is a form of energy. It is the essence of some activities such as music and speech, and a by-product of other activities such as manufacturing and transportation. When sound 
becomes excessive, it is disruptive to quiet activities and annoying to the listener. This is when sound is treated as noise. Sound travels in waves through the air; it can be absorbed or reflected, and it weakens over distance. There are three characteristics of noise that impact the way in which the person who hears the sound, responds to it: loudness, duration, and pitch.

The loudness of the sound is described as the sound pressure and can be measured in decibels. Because sound becomes weaker over distance, the closer one is to a sound source, the louder it is. Louder sounds mask quieter sounds. For instance, two people walking on a sidewalk may converse with normal traffic passing by, but conversation is interrupted when motorcycles go by.

The duration of a sound is simply how long it lasts. A noise is considered to be more severe if it lasts a long time. For example, if one listens to a rock band for a few minutes, there are not likely to be any after effects, but if one listens for several hours, there is likely to be a ringing sensation in the ears several hours afterward.

The pitch of a sound is the frequency of the sound waves and can be measured in Hertz $(\mathrm{Hz})$. Higher pitch noises within the hearing range are more disturbing to humans than lower pitches because human hearing is less sensitive to lower frequencies. The range of frequencies perceived by humans is $20 \mathrm{~Hz}$ to $15,000 \mathrm{~Hz}$. A sound that is twice the the frequency of another is one octave higher. Most noises are a combination of actual frequencies. Some noises contain frequencies that are pure tones, such as that emitted by a tuning fork. Pure tones, like high pitched sounds, are more disturbing to the listener. An example of noise that is not necessarily loud, but that is extremely annoying is the sound of fingernails on a chalkboard. The "whine" 
of a turbofan jet engine is a combination of several pure tones, and is not only loud, but also truly annoying.'

\section{Aircraft Noise}

Airport noise, or aircraft noise can be described in two ways: 1) the engine that makes the noise, or 2) the operation of the aircraft at the airport. The first method relies on the technological aspects of engine design and propulsion systems. The second method refers to the way in which the aircraft is used, e.g. takeoffs, taxiing, engine run-ups.

Aircraftengine. Jet aircraft were invented in the 1950's and are the major contributors to airport noise. A jet engine is powered by the compression of air and the combustion of fuel. The other type of engine is the traditional piston engine that is used by automobiles and general aviation aircraft. In airplanes, jet engines are used in combination with turbines, or fans, which convert engine power to drive moving parts.

There are three types of jet aircraft: turbojet, turbofan, and turboprop. The first generation jet aircraft are turbojets, such as the DC-8. The noise from turbojets comes from the high velocity exhaust gases which range from high to low frequencies. The turbofans have replaced turbojets. They are more efficient and expel exhaust at lower velocities. While this improvement makes the engine quieter, the sound of other moving parts, like the fans, is more prominent. The fan noise is the "whine" that is characteristic of this type of aircraft. ${ }^{2}$

The turboprop is an aircraft that has a jet engine, but turbines are used to power propellors or rotors. Certain helicopters and airplanes are in this category. Helicopter noise 
comes from the tail rotor which spins very fast, and from the main rotor which spins more slowly, but produces a "blade slap." The general aviation aircraft utilize the piston engine to drive the propellors. The moving parts and the engine cxhaust contribute to noise.

Aircraft operation. Seven different operations are associated with airport noise: 1) taxiing, 2) departure, 3) approach, 4) landing roll, 5) training flights, 6) maintenance, and 7)

ground equipment.' Noise from operations on the ground speads outward or horizontally. Noise berms or barriers are effective in containing this type of noise. Once the aircraft is in the air, however, noise emanates downward, and noise barriers are ineffective.

Some air operations have distinct sounds. During a takeoff, the primary noise is from the jet exhaust, but during a landing, noise comes from machinery parts. The whine from the exhaust is high-pitched and more annoying, but dissipates more quickly. The roar or rumble is low-pitched and less annoying, but lasts longer. Training flights contribute to a high number of operations and increased noise.

Engine run-ups on the ground required for maintenance or before takeoff is a serious problem at some airports. The noise impact is less severe directly behind the aircraft. Reverse thrust on the landing roll and taxiing movements are other sources of ground noise.

\section{Cumulative Noise}

The decibel $(\mathrm{dB})$ is the basic unit used to measure the loudness of a sound. The decibel scale is not an algebraic scale; it is a logarithmic scale, similar to the Richter scale used for measuring earthquakes. A sound that is $10 \mathrm{~dB}$ higher than another sound is twice as loud. The 
decibel values of two simultaneous sounds can not be added together to get a total sound level. The louder sound has the effect of overpowering or drowning out the quieter sound. In reality, several sounds occur simultaneously. For example, one airplane may be taking off while another is taxiing to a runway. The following table shows how to add two sounds together to quantify the cumulative effect.

Table 3.1 Adding Decibels: Two Sounds of Different Values

\begin{tabular}{|c|c|}
\hline When two decibel values differ by: & Add the following amount to the higher value: \\
\hline 0 or $1 \mathrm{~dB}$ & $3 \mathrm{~dB}$ \\
\hline 2 or $3 \mathrm{~dB}$ & $2 \mathrm{~dB}$ \\
\hline $4 \operatorname{tos} \mathrm{dB}$ & $1 \mathrm{~dB}$ \\
\hline 9 or more $\mathrm{dB}$ & $0 \mathrm{~dB}$ \\
\hline
\end{tabular}

Source: Bolt Beranek and Newman, Noise control plan development, 1979, p. 7.

In other words, if there are two equal sounds, a louder sound is the result, but if there are two unequal sounds, the louder sound is the dominating one and masks the other sound.

When there are multiple sound sources, for example, one airplane circling in the traffic pattern, one landing, two taxiing, and several ground vehicles moving, there is another method used to add them all together. When adding more than two sounds, start by adding the two lowest values using the above method; use that sum with the next higher value and continue upward. The following example shows the values of five simultaneous sounds in the left column. The number at the bottom right is the cumulative total. 


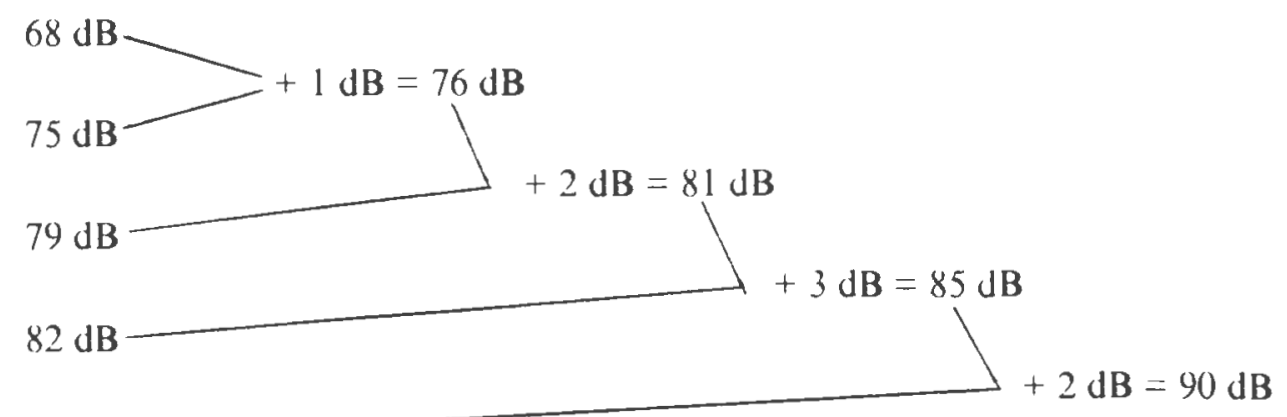

$88 \mathrm{~dB}$

In this type of situation, with sounds at differing levels, the total sound is not much greater than the loudest one. Simultaneous sounds of the same value are added in a different way as Table 3.2 shows. For example, if many people are talking at the same level, a loud hum is the result.

Table 3.2 Adding Decibels: Many Sounds of the Same Value

\begin{tabular}{|c|c|}
\hline Number of equal sound levels & Add to that level \\
\hline 2 & $3 \mathrm{~dB}$ \\
\hline 3 & $5 \mathrm{~dB}$ \\
\hline 4 & $6 \mathrm{~dB}$ \\
\hline 5 & $7 \mathrm{~dB}$ \\
\hline $6-7$ & $8 \mathrm{~dB}$ \\
\hline 8 & $9 \mathrm{~dB}$ \\
\hline $9-10$ & $10 \mathrm{~dB}$ \\
\hline $\mathrm{N}$ & $10 \log \mathrm{N} \mathrm{dB}$ \\
\hline
\end{tabular}

Source: Bolt Beranek and Newman, Noise control plan derelopment, 1979. p. 9.

To compare five simultaneous events of equal loudness to the previous example of differing 
loudness, five events of $88 \mathrm{~dB}$ each has a cumulative value of $95 \mathrm{~dB}$, while five events with 88 $\mathrm{dB}$ as the highest value has a cumulative total of $90 \mathrm{~dB}$. Using these addition methods, any combination of sounds can be added together.

\section{Measurement Scales}

This section introduces the scales used to measure sound. They are presented in somewhat of a progressive order with the most simple scales at the beginning. Some are used to measure single events, and others are cumulative measures. Different scales are used to accommodate varying degrees of required specificity or technicality. The capability of available sound measuring devices may play a role in determining which scale to use. Note that these are simplified definitions and extensive mathematical calculations are required to compute some of the cumulative noise indicators.

$\mathrm{dB}$ - Decibel scale.

SEL - Sound Exposure Level in relation to one event.

$\mathrm{JB}(\mathrm{A})$ - Decibel scale with A-weighted sound level. The lower frequencies are deemphasized to emulate human hearing.

$\mathrm{L}_{\mathrm{eq}}$ - Equivalent sound level. This is the cumulative SEL measured in $\mathrm{dB}(\mathrm{A})$ for varying time periods. For example, it may be an 8-hour period that is representative of a work day.

PNdB or PNL - Perceived Noise Level. This measures a single noise event and is adjusted for pitch or frequency.

CNR - Composite Noise Rating. This is a cumulative noise measure using PNL and adjusted for number of aircraft operations, time of day, and runway usage. 
EPNdB or EPNL - Effective Perceived Noise Level. This measures a single noise event and is adjusted for the frequency and duration of the sound. (One event, such as an airplane landing, can have different frequencies for varying periods of time.) This is the measurement used as the standard by the FAA and the ICAO. It is $12 \mathrm{~dB}$ higher than the $\mathrm{dB}(\mathrm{A})$ scale at a point in time. ${ }^{4}$

NEF - Noise Exposure Forecast. This is a cumulative 24-hour noise level using the EPNL scale and adding $12 \mathrm{~dB}$ to noise events between 10 p.m. and 7 a.m. This measurement replaces the CNR.

$\mathrm{L}_{\mathrm{dn}}$ - Day/night sound level. This is the average noise level over a 24-hour period measured in $\mathrm{dB}(\mathrm{A})$. Nighttime sounds, between $10 \mathrm{p} . \mathrm{m}$. and $7 \mathrm{a} . \mathrm{m}$. are increased by $10 \mathrm{~dB}$ because they are perceived to be louder when the ambient noise level is lower. It is not corrected for frequency. This measurement has been adopted by the FAA, partly because it easier to measure than NEF.'

CNEL - Community Noise Equivalent Level. This is California's version of $\mathrm{L}_{\mathrm{dn}}$ with an additional correction of $5 \mathrm{~dB}$ for sounds between 7 p.m. and 10 p.m.

There are many scales used for measuring noise. The NEF is the most accurate measure of perceived noise over time, but it is also the most difficult to measure. The $\mathrm{L}_{\mathrm{dn}}$ is the method used by the FAA because of its simplicity in measurement and reflection of community values. Standards within this measurement have been adopted, although they may not depict the actual extent of the noise problem. Residences lying outside of noise contours are affected by noise in reality but not on paper. Sound levels for events and typical ambient noise are shown in Figure 3.1.

\section{Noise Contours}

Noise contours are lines drawn around an airport runway system that depict sound levels in the surrounding area; each line represents a certain value or category of loudness. They 
Figure 3.1 Typical Sound Levels

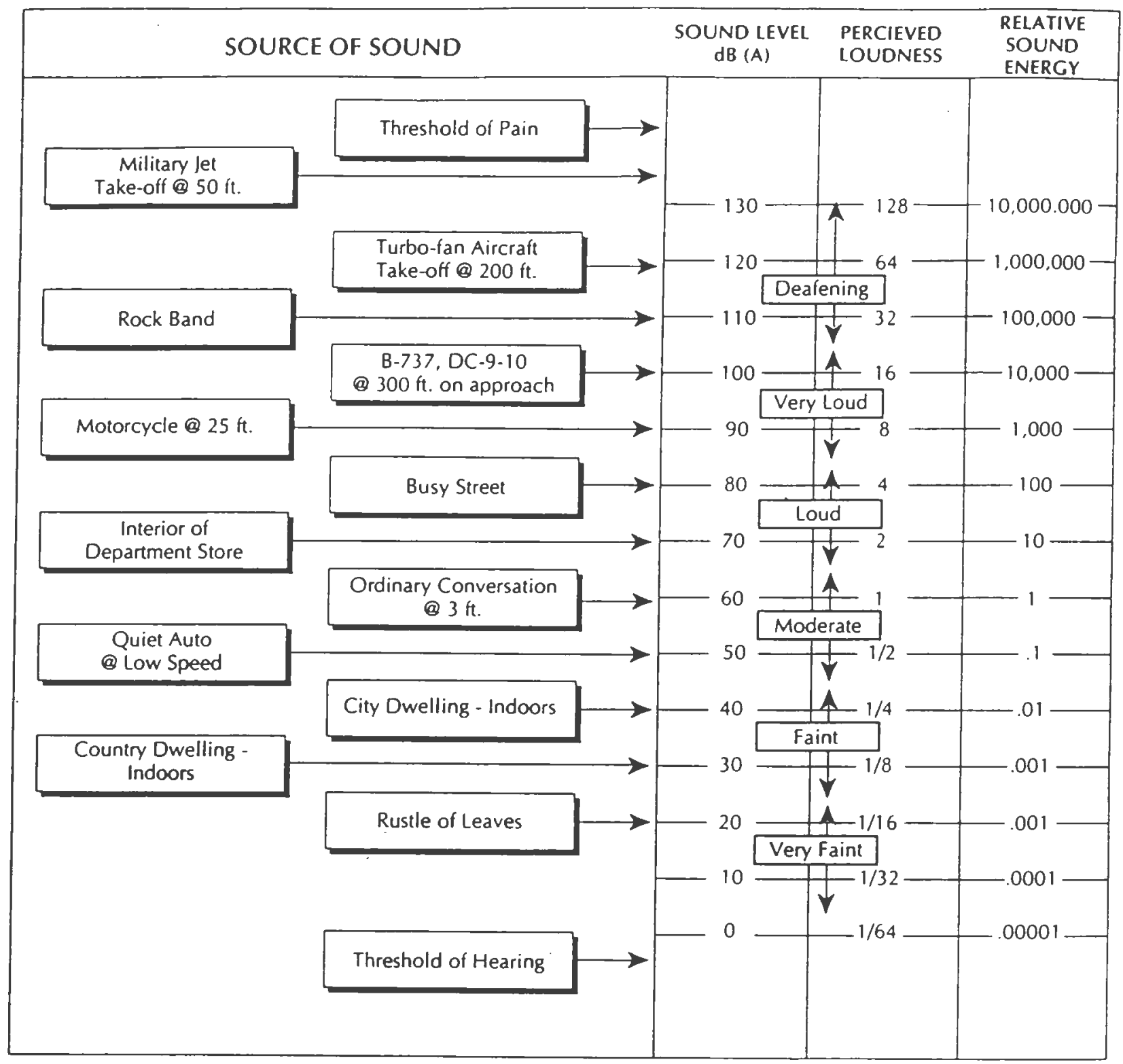

Source. Coffman Assaciates, Inc., Masice Plan Update and Noise Exposure Map Update. Por Columbus International Airpor 
look similar to topographical contours with the runway appearing as the top of the hill. Noise contours run parallel to the runway and extend beyond each end of it. The noise generated by an aircraft is loudest directly below it. Figure 3.2 shows a typical noise contour of a fourrunway airport with the land use guidance zones that were mentioned in Chapter 2 in Table 2.2 Land Use Guidance Chart.

An accurate noise contour map is generated by a complex computer model. The FAA utilizes an Integrated Noise Model (INM) to perform calculations. The data that is needed for in put in the INM are:

a) Airport map indicating runway length, alignment, landing thresholds, takeoff start-of-roll points, and flight tracks out to 30,000 feet.

b) Annual average daily airport activity levels including number and type of aircraft, flight track utilization, and time of day.

c) Aircraft takeoff and landing glide slopes, glide slope intercept altitudes, takeoff weight, engine power settings, and existing noise abatement procedures.

d) Topographical and airspace restrictions that dictate flight paths.

e) Government furnished aircraft noise characteristics.

f) Airport elevation, wind conditions and average temperatures."

The noise contours that are generated by this data may be affected by local topography and vegetation that is not accounted for in the model. Noise measuring and monitoring systems are available so that site-specific data can be verified or updated.

The alternative to simulating a noise contour through the use of a computer is actual 


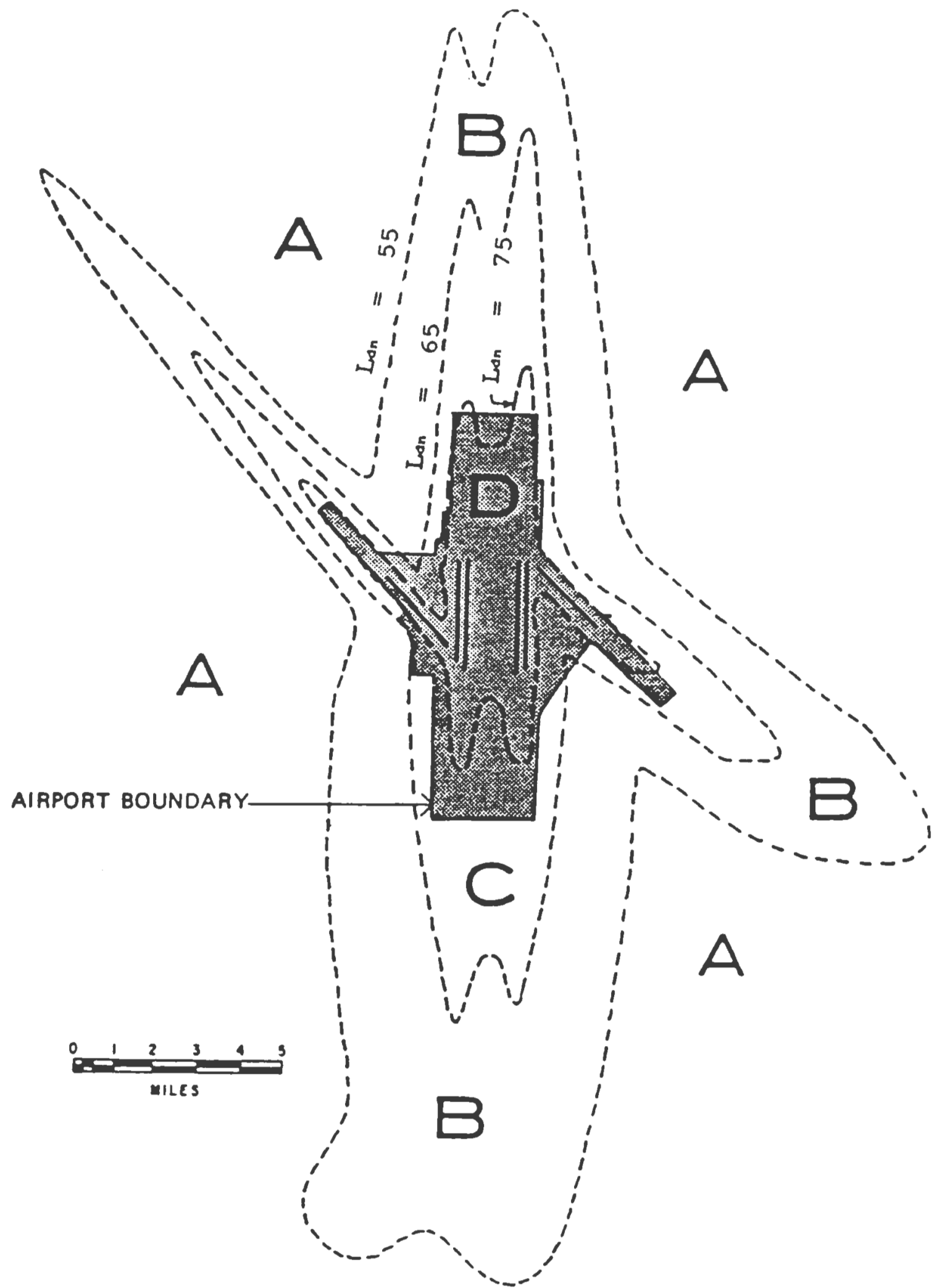

Figure 3.2 Typical Noise Contour

Source: Ashford and Wright, Airport Engineering, 1992, p. 500. 
field measurements. This would involve noise-measuring devices at many locations for extended periods of time. It is equipment, time, and labor intensive, and therefore expensive.

Another method of plotting noise contours is the Noise Exposure Forecast. This is an approximation and is not acceptable to the FAA within Part 150 guidelines. It is, however, useful when time constraints prevent the extremely detailed data collection that the INM requires, or when predicting different scenarios of possible long-term future airport usage. This method requires only the estimation of day and night jet aircraft operations. The number of nighttime operations is multiplied by 17 and added to the number of daytime operations. The total is used in the following table to plot the contour lines.

Table 3.3 Distances for Approximate NEF Contours

\begin{tabular}{|c|c|c|c|c||}
\hline \multirow{2}{*}{\begin{tabular}{c} 
Effective number of $\begin{array}{c}\text { operations } \\
\text { (night } \mathrm{x} 17+\text { day) }\end{array}$ \\
\cline { 2 - 5 }
\end{tabular}} & side of runway & end of runway & side of runway & end of runway \\
\hline $0-50$ & 1000 feet & 1 mile & 0 & 0 \\
\hline $51-500$ & 0.5 mile & 3 miles & 1000 feet & 1 mile \\
\hline $501-1300$ & 1.5 miles & 6 miles & 2000 feet & 2.5 miles \\
\hline more than 1300 & 2 miles & 10 miles & 3000 feet & 4 miles \\
\hline
\end{tabular}

Source: CLM/Systems, Inc., Airports and their environments, 1972, p. 108.

This method is relatively simple and allows for error in the estimate because the range of operations is large. Figure 3.3 shows an example of NEF 30 and NEF 40 noise contours for 51-500 effective operations drawn by this method. End of runway measurements are taken from 


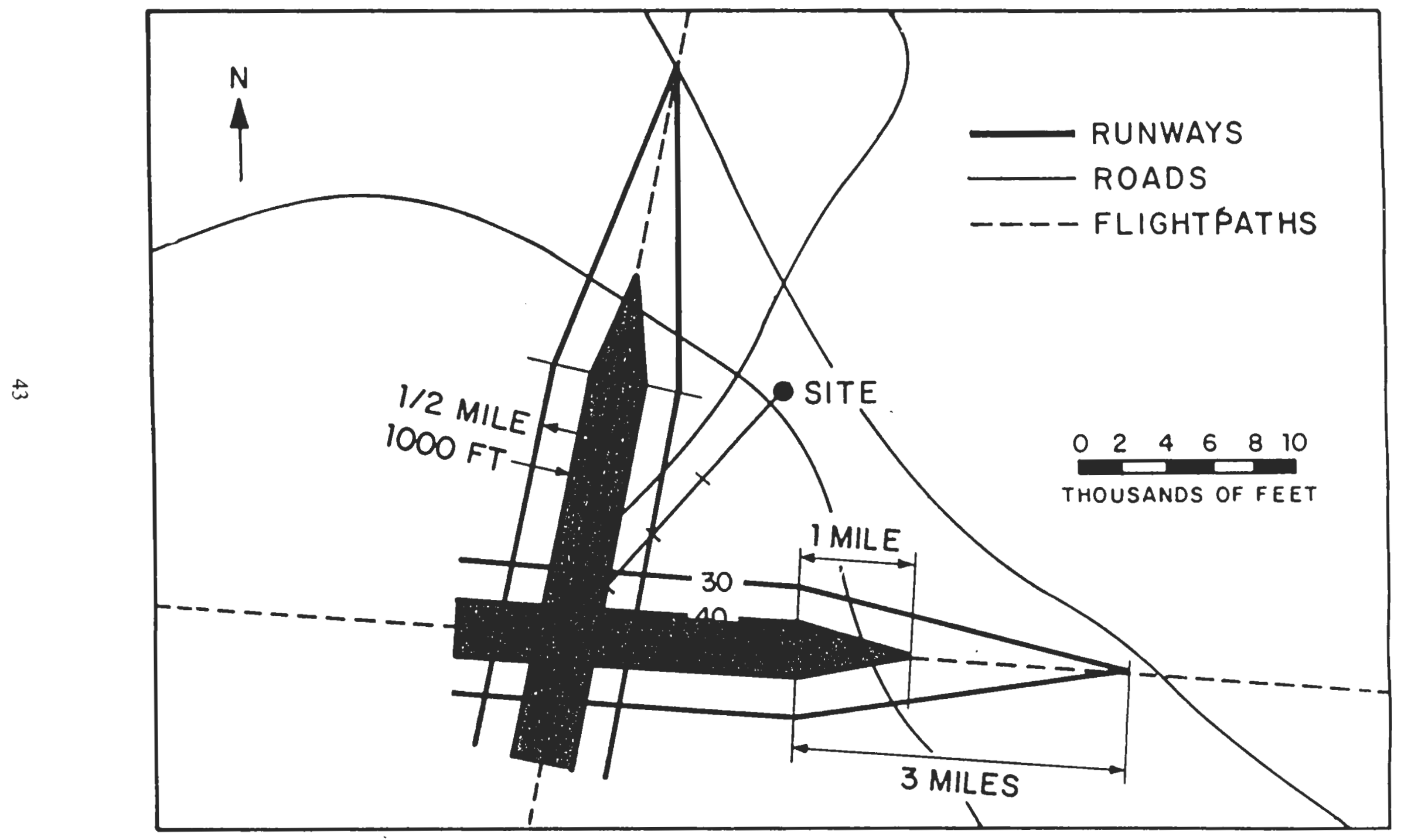

Figure 3.3 Noise Contour Using NEF Method of Approximation Source: CLM Systems, Inc., Airports and Their Environment, 1972, p. 108. 
the centerline of each end of the runway, and side of runway measurements are taken from the centerline of the runway and run parallel to it. This is the method that will be used in the noise contour map for Quonset State Airport because the number of future operations can only be estimated. The author also does not have access to FAA computer models. NEF contours are easily converted to $\mathrm{L}_{\mathrm{dn}}$ contours by the Land Use Guidance Chart in the previous chapter. One drawback of this method is that it lacks an approximate distance to the NEF 20 contour.

\section{Noise in the Community}

The noise from the airport that becomes problematic can be discussed in two ways. Noise control can be addressed as a function of land use or activities that occur in a given place; or, it can be described as a function of the people who are impacted. Land use is appropriate when designing a zoning ordinance or other remedy, but it is important to remember that people, not houses and land, suffer from noise.

\section{Land Use Sensitivity to Noise}

Some land uses are more sensitive to noise than others. Inevitably, to describe this situation, land use must be quantified and categorized. The FAA has devised a Land Use Guidance Chart for Land Use Noise Sensitivity Interpolation. It is quite detailed and breaks down generic land use categories into more specific activities. The entire chart appears in Appendix A. This chart references the Land Use Guidance Chart that appeared in the previous chapter to categorize acceptable land uses into zones of increasing noise. It is shown here again 
in Table 3.4 to supplement the discussion on land use. CNR (Composite Noise Rating) is not used in this discussion because it is not a standard measurement used by the FAA, and CNEL (Community Noise Exposure Level) is not discussed either because it is used only in the State of California.

Table 3.4 Land Use Guidance Chart

\begin{tabular}{|c|c|c|c|c|c|c|c|}
\hline \multirow{2}{*}{$\begin{array}{l}\text { Land use } \\
\text { guidance } \\
\text { zones }\end{array}$} & \multirow{2}{*}{$\begin{array}{l}\text { Noise } \\
\text { cxposure } \\
\text { class }\end{array}$} & \multicolumn{4}{|c|}{ Aircraft noise estimating methodologies } & \multirow{2}{*}{$\begin{array}{l}\text { HUD noise } \\
\text { assessment } \\
\text { guidelines }\end{array}$} & \multirow{2}{*}{$\begin{array}{l}\text { Suggested noise } \\
\text { controls }\end{array}$} \\
\hline & & $L_{t n}$ & NEF & CNR & CNEL & & \\
\hline $\mathbf{A}$ & minimal & $\begin{array}{l}0 \\
\text { to } \\
55\end{array}$ & $\begin{array}{l}0 \\
10 \\
20\end{array}$ & $\begin{array}{l}0 \\
\text { to } \\
90\end{array}$ & $\begin{array}{l}0 \\
\text { to } \\
55\end{array}$ & $\begin{array}{c}\text { clearly } \\
\text { acceptable }\end{array}$ & $\begin{array}{l}\text { normally requires no } \\
\text { special considerations }\end{array}$ \\
\hline $\mathbf{B}$ & moderate & $\begin{array}{l}55 \\
10 \\
65\end{array}$ & $\begin{array}{l}20 \\
\text { to } \\
30\end{array}$ & $\begin{array}{l}90 \\
10 \\
100\end{array}$ & $\begin{array}{l}55 \\
\text { to } \\
65\end{array}$ & $\begin{array}{l}\text { normally } \\
\text { acoceptable }\end{array}$ & $\begin{array}{l}\text { land use controls } \\
\text { should be considered }\end{array}$ \\
\hline $\mathrm{C}$ & significant & $\begin{array}{l}65 \\
\text { to } \\
75\end{array}$ & $\begin{array}{l}30 \\
\text { lo } \\
40\end{array}$ & $\begin{array}{l}100 \\
10 \\
115\end{array}$ & $\begin{array}{l}65 \\
10 \\
75\end{array}$ & $\begin{array}{c}\text { normally } \\
\text { unacceptable }\end{array}$ & $\begin{array}{l}\text { land use, easements, } \\
\text { and other controls } \\
\text { rocommended }\end{array}$ \\
\hline $\mathrm{D}$ & severe & $\begin{array}{l}75 \\
\text { and } \\
\text { over }\end{array}$ & $\begin{array}{l}40 \\
\text { and } \\
\text { over }\end{array}$ & $\begin{array}{l}115 \\
\text { and } \\
\text { over }\end{array}$ & $\begin{array}{l}75 \\
\text { and } \\
\text { over }\end{array}$ & $\begin{array}{c}\text { clearly } \\
\text { unacoeptable }\end{array}$ & $\begin{array}{l}\text { contain within airport } \\
\text { boundary or positive } \\
\text { controls recommended }\end{array}$ \\
\hline
\end{tabular}

Source: Federal Aviation Administration, Advisory Circular 150/5050-6, 1977.

Zone $\mathrm{A}$ is depicted as having minimal noise impact and is acceptable for all land uses. Zone $\mathrm{B}$ has moderate noise exposure, and all land uses may not be acceptable without soundproofing added to buildings. Zone $\mathrm{C}$ is increasingly noisy, and some uses such as residential are unacceptable, while uses such as manufacturing are. Zone D is an area of severe noise exposure and should be contained within the boundary of the airport.

A summary of the Land Use Guidance Chart for Land Use Noise Sensitivity 
Interpolation appears in Table 3.5. The full chart in Appendix A is more detailed and may give a range of acceptable zones for certain uses or state exceptions if certain soundproofing techniques are used.

Table 3.5 Acceptable Land Uses within Noise Zones

\begin{tabular}{|c|c|c|c|}
\hline Land use & Zone & $\mathrm{L}_{\mathrm{dn}}$ & NEF \\
\hline Single-family residential & A & $0-55$ & $0-20$ \\
\hline Multi-family residential & B & $55-65$ & $20-30$ \\
\hline General manufacturing & C-D & $65-75+$ & $30-40+$ \\
\hline Precision manufacturing & B & $55-65$ & $20-30$ \\
\hline Transportation facilities & D & $75+$ & $40+$ \\
\hline Retail trade & C & $65-75$ & $30-40$ \\
\hline Offices and government buildings & B & $55-65$ & $20-30$ \\
\hline Educational buildings & A-B & $0-65$ & $0-30$ \\
\hline Cultural activities & A & $0-55$ & $0-20$ \\
\hline Amusements, parks, and recreation & B-C & $55-75$ & $20-40$ \\
\hline Agriculture and resource extraction & D & $75+$ & $40+$ \\
\hline Undeveloped areas (varies) & A-D & $0-75+$ & $0-40+$ \\
\hline
\end{tabular}

Source: Adapted from Horonjeff and McKelvey, Planning and design of airports, 1983, p. 583.

Single-family residential, schools, and cultural activities are considered the most sensitive uses, and require the quietest environment using normal construction. Indoor sound levels are usually $20 \mathrm{~dB}$ lower than outside, and can be $30 \mathrm{~dB}$ lower in a tight masonry building. Because soundproofing can be effective, some uses may be permitted in a higher noise zone. 
The majority of noise complaints come from residential areas, because the decreased ambient noise at night, especially in quiet neighborhoods, causes airport noise to seem even louder.-

\section{Community Reaction to Noise}

People have certain expectations of the quality of life in different types of neighborhoods. Urban residents expect a loud environment with noise coming from many sources, while rural residents expect the opposite. Excessive noise can be disruptive to many home and office activities in all types of environments, which creates tension over a period of time. Communities react to noise in different ways based on several different physical and environmental factors:

a) Ambient noise level of the neighborhood - Noise is more noticeable in a rural or suburban setting than in an urban setting.

b) Time of day - Noise is more noticeable at night.

c) Season - Noise is more noticeable in the summer when windows are open and more activities occur outdoors.

d) Predictability of the noise - Unexpected noise is more noticeable. ${ }^{7}$

More psychological factors that impact individual attitudes have been analyzed also such as:

a) Feelings about the necessity and preventability of noise

b) Responsivity of the airport to concerns and complaints

c) Perception of the value of the activity causing the noise

d) Attilude toward the environment

e) Fear associated with the noise

f) General personality and disposition of the person ${ }^{8}$

More qualitative measures are used to describe a person's attitude toward noise. Some questions might appear on a survey administered to someone who lives near an airport regarding the disturbance of sleep, inability to sleep, interruptions in conversation, and 
interference with studying or other critical activity. The following table shows typical adjectives used in relation to an activity. The noise level in the first columne refers to a single noise event, not to average sound levels. The table is useful in associating numerical values with human factors.

Table 3.6 Qualitative Descriptors Applicable to Residential Areas

\begin{tabular}{||c|c|c|c||}
\hline \multirow{2}{*}{$\begin{array}{c}\text { Noise level } \\
\mathrm{dB}(\mathrm{A})\end{array}$} & \multicolumn{2}{|c|}{ Conversation disturbance - indoors } & \multirow{2}{*}{$\begin{array}{c}\text { Outdoor } \\
\text { environment }\end{array}$} \\
\cline { 2 - 3 } & Windows open & Windows closed & quiet \\
\hline \hline 65 & just noticeable & none & generally acceptable \\
\hline 75 & moderate & just noticeable & noisy \\
\hline 85 & severe & moderate & excessively noisy \\
\hline 95 & extreme & severe & \\
\hline
\end{tabular}

Source: Bolt Beranek and Newman, Noise control plan development. 1979, p. 31.

According to the literature, annoyance is the term used most often to describe how people feel about airport noise. That is a somewhat vague and subjective term and difficult to quantify. A study done in Illinois concluded that relative annoyance to noise was highly correlated to the computer generated contour lines. Another conclusion was that people who were "highly annoyed" with aircraft noise were three to four times more likely to be highly annoyed with other noises." A study was done in Georgia to compare the annoyance levels of residents in homes that had been acoustically treated with those that were not. The conclusion was that people in soundproofed homes were equally as annoyed with aircraft noise as everyone 
else. This supports the idea that psychological factors are as important as physical factors in noise disturbance.

There have been no cases of hearing loss in communities adjoining airports. Hearing impairment is an obvious result of severe prolonged noise exposure, but are there other health related problems that could be caused by noise? None of the studies that have been done have been able to show any correlation. Nor is there any correlation between noise exposure and cognitive ability. ${ }^{\mid 0}$

A very difficult aspect of trying to accommodate airport neighbors is the nature of the quantitative noise measurement. A $65 \mathrm{~L}_{\mathrm{dn}}$ contour line may fall between two houses; the house on the inside may receive free soundproofing and air conditioning from the airport, while the house just outside may not receive anything even though there may be no perceivable difference in the noise environment to the residents. It would be desirable to treat a neighborhood as a whole, even if a contour line bisects it, but soundproofing and other noise mitigation methods are costly.

\section{Noise Mitigation Techniques}

There are many techniques available to reduce or mitigate noise in a community. Some measures are more effective than others, and some are more costly than others. They can be categorized in several different ways. One approach describes the end result rather than the actual method: preventive (such as land use planning) stops the problem before it starts, corrective (soundproofing) reduces noise where it already exists, and compensatory (purchase 
of a noise easement) does not reduce noise, but pays a landowner for the right to make noise. Another way of categorizing noise abatement techniques is to describe the actual method: land use planning, source reduction, physical improvements (soundproofing, noise berms), operational procedures (runway preference, curfews). The other way to classify noise mitigation methods is by the agency under whose authority the technique is implemented: federal government, local government, airport owners, air transportation industry. In this section, noise abatement will be discussed according to the agency responsible for the implementation, and secondarily by the nature of the method itself.

The federal and state governments are generally not involved in the actual implementation of noise reduction. (Rhode Island is an exception because it owns all of the public airports.) Federal and state governments formulate policy, set standards, enact enabling legislation, and provide funds. The aircraft manufacturers and the airlines react to standards set by the federal government; they build quieter new aircraft or retrofit existing aircraft with "hushkits" to make them less noisy. When the responsible agency is a regional or metropolitan government, it may act in different capacities; it may set policy and also be responsible for implementation. Because Rhode Island does not have any agencies of this type, they will not be addressed. The two primary agencies that will be discussed are the local governments and the airport administration or management. This is a general discussion of methods, and all of them may not necessarily apply to North Kingstown, Jamestown, or the State of Rhode Island. 


\section{Local Government}

Local governments have several options by which to control noise, assuming they have jurisdiction over impacted land. They can work through the control of land use, rights of land ownership, and structures built on the land.

Land use planning. Land use planning is the ideal way of controlling the impact of airport noise because it is preventive; all noise-sensitive uses would be located away from the airport. Future development could be directed away from the airport through a capital improvement program. It can be difficult to implement because many major metropolitan airports are located within already developed urban or suburban areas. Suburban sprawl and jet aircraft were unforeseen when some airports were sited. The following techniques are used in land use planning.

Comprehensive planning. The comprehensive planning process outlines community goals and objectives in many functional areas including the economy, transportation, recreation, the environment, and land use, among others. An airport is a part of the community that has an impact on most of these functional areas. The importance of the airport must be evaluated to establish a effective noise plan that does not compromise the airport's contribution to the community.

Zoning. Zoning is a tool through which comprehensive plans are implemented. Zoning controls many aspects of land including its use, the allowable density of development, and the size and placement of buildings. Height and hazard zoning already exists around most airports. Land surrounding airports should be zoned for compatible uses such as industrial or 
agricultural; these uses are not as sensitive to noise as residential areas are, and they tend to require large parcels of land which can act as a buffer around the airport. Less severely noise impacted areas are appropriate for commercial uses, and quiet areas should be reserved for residential and institutional uses. Cumulative zoning, i.e. allowing higher uses such as residential into lower zones such as commercial, should not be allowed. Turnover of land use from residential to commercial occurs frequently in normal land use trends and can be encouraged through zoning. Because zoning is not retroactive, nor is it permanent, it can not be used by itself in a noise program.

Overlay zones. This is a relatively new technique that complements traditional zoning. An example of a overlay zone is a historic district; many uses may be permitted, but special regulations apply to the appearance of a building. A noise overlay zone could be established that corresponds to the noise contours of the airport; there could be different zones for varying levels of noise. Within this zone, other measures, such as soundproofing, building code amendments, and disclosure could become effective.

Land acquisition. When noise becomes so severe as to interfere with use of the property or reduce its value, the only option may be for the town to purchase the land. The town could then rezone it and sell back the land to support a use that is not sensitive to noise, retain the land for open space, or maintain it in a land banking program for future airport use. This is a permanent but expensive solution. This method is available also to the airport owner which may or may not be the town.

Rights of land. It is possible within the American legal system to separate land 
ownership into a bundle of distinct rights, e.g. air rights, mineral rights, development rights, etc. Rights can be bought and sold and restrictions can be placed on property deeds to waive certain rights. The following are applicable to noise abatement. They can be used by any agency with powers of eminent domain, not necessarily the town.

Transfer or purchase of development rights. These rights can be transferred to a different parcel of land in a different location if one is owned by the same person. For example, a developer may want to build a subdivision on land near the end of a runway. The town may decide that instead of building units at this location, the developer can overbuild on a different parcel of land further from the airport in order to recoup losses from the first parcel. If this arrangement is not possible, the town may have to buy the development rights to the land without actually purchasing the land. The town may also act as a broker and buy development rights to a farm, for example, and sell those rights to a developer at a different site.

Noise or avigation easements. An easement is simply a grant of certain rights to one with regard to the land of another. For example, a power company possesses an easement to run power lines across the owner's property. A similar arrangement can be made with respect to airports. The right to make noise over one's property as well as the right to fly in the airspace over one's property can be purchased, granted, or condemned, and a restriction can be placed on the deed to insure the continuity of the easement.

Building techniques. There are several building techniques that contribute to interior noise reduction. They can be used in conjunction with an overlay zone as explained above.

Acoustic clustering. This is a method of arranging buildings on a site to form a noise 
shadow. Noise travels in a straight line, much like sunlight. While ambient light in the shade is still relatively bright, it is less severe than direct sunlight. Acoustic clustering may place windowless walls toward the source of the noise and use the building arrangement to direct or block the path of noise somewhat. This does not alleviate noise from directly above the site, but rather from one side, so it is most useful close to the airport.

Building code. A more stringent building code in noise impacted areas would solve interior noise problems in future construction. The code might require thicker walls and insulation, double or triple pane windows, sound absorbing material in ventilating and air conditioning systems, caulking, and carpeting in bedrooms. The homeowner can even benefit from these requirements through lower heating costs. The code might also require air conditioning to minimize the need to open windows and prohibit fireplaces and through-door mailboxes. Soundproofing a home as it is built costs between four and ten percent of the total cost. Soundproofing an existing home costs between 10 and 25 percent of the cost of the house."

Disclosure. In the overlay zone surrounding the airport, full disclosure regarding the impact of the airport should be required of real estate and rental agents. Oftentimes, home buyers will visit on weekends when there are fewer airport operations and may not be aware of actual noise levels. A notice may also be placed on the plat to this effect.

\section{Airport Administration and Management}

Just as municipalities have an array of noise reduction methods, the airport 
management also has a number of options that can be implemented to mitigate noise. Some methods require physical changes to the airport; some are simple regulations relating to the use of the airport, and some are adjustments in the operation of the aircraft. These techniques have varying degrees of effectiveness, and they are implemented with respect to the exact condition and direction of the noise. If the airport management is not the same entity as the municipality, as is the case with Quonset State Airport, then the airport is responsible for corrective noise mitigation, such as soundproofing of buildings, that was discussed under a previous section.

Physical changes to airport. These are typically construction projects that are capital intensive, but effective.

New runways. Runways can be built that are oriented in a different direction to avoid or eliminate flights directly over residential areas. This is dictated by the availability of land and by the direction of prevailing winds.

New taxiways. Additional taxiways that reduce the distance an aircraft must travel on the ground can lead to a reduction in noise. This is less expensive than the previous strategy.

Building arrangement. Hangars and terminal buildings can be placed strategically or relocated to block or deflect sound, or new hangars can be built to bring former outdoor maintenance operations indoors.

Noise barriers. Earth berms or walls can be built on airport property to deflect noise; they must be long and continuous in order to be effective. Landscaping and the use of vegetation to muffle noise is generally not very effective because the planting has to be very dense and over a very large area. 
Airport use regulations. These are a simple and very cost-effective means to control airport noise, but they may also limit the capacity of the airport and may interfere with the services that are provided to the community.

Preferential runway and flight path. These are not capacity restricting regulations but may serve only to shift a noise problem to a different population. If that is the case, a rotational runway schedule can be arranged so as to spread out noise more equitably. Preferential runways and flight paths are used for similar reasons as the new runway option discussed above, but utilizes existing facilities. At coastal airports, nights over the water are generally perceived to be less intrusive by many people.

Ground restrictions. This applies to engine testing and run-ups and to the general movement of aircraft along taxiways and apron space.

Curfews. This limits or forbids aircraft operations during specified nighttime hours and places a direct limit on capacity and service. Because of the different time zones around the world, it may be difficult to schedule flights to certain cities. Nonetheless, this regulation is popular with nearby residents because it does not merely reduce the noise, but altogether eliminates it at night.

Aircraft type restrictions. Some airports have banned Stage II aircraft even though they meet federal standards. Variations of this rule may ban Stage II planes only at night or place a cap on the number of daily operations.

Noise management. This is a system developed by the airport that works in two ways: 1) Noise-based landing fees make it more expensive for airlines to use louder planes and 
encourages the use of quieter planes. This may place some airlines at a disadvantage and impact service. 2) A total noise budget can be established on a point system, and airlines can buy points. Then, they can either have fewer flights with louder planes, or more flights with quieter planes. Either way, total noise will not be exceeded.

Aircraft operation. These types of procedures can be mandated at airports but must be approved by the FAA for reasons of safety. They are already standard regulations in many airports. The only cost incurred is excess fuel if a reduction in engine efficiency is the result of the procedure.

Engine thrust. Adjusting engine power settings during takeoff and minimizing use of reverse thrust during landing can achieve a reduction in noise.

Landing and takeoff profile. A steeper glide slope during landing or a steeper climb during takeoff can be accomplished safely and reduce the area of land exposed to low level flights which are noisier. The sooner an aircraft reaches a higher altitude, the more the noise will be dispersed.

An effective noise compatibility plan must be developed in consideration of all of the available methods and their costs and benefits. Airports can grow in harmony with a community if thought is given to land use planning and the future growth and necessity of the airport to the region beyond the borders of the town. Like other planning efforts, it is collaborative and requires participation from the public. 


\section{Notes}

1. Bolt Beranek and Newman, Inc., Noise control plan development, Seminar notes prepared for U.S. Department of Transportation, Federal Aviation Administration (1979): 14.

2. CLM Systenus, Inc., Airports and their environments: A guide to environmental planning, prepared for U.S. Department of Transportation, Office of the Secretary, Office of the Assistant Secretary for Environment and Urban Systems, (1972): 78.

3. Bolt Beranek and Newman, Inc., Noise control plan development, Seminar notes, p. 51.

4. Norman Ashford and Paul Wright, Airport engineering, 3rd ed., (New york: John Wiley and Sons, Inc., 1992): 489.

5. Ashford and Wright, 496; and Bolt Beranek and Newman, 20.

6. U.S. Department of Transportation, Federal Aviation Administration, Noise control and compatibility planning for airports, Advisory Circular 150-5020-1 (1984): 19.

7. U.S. Department of Transportation, Federal Aviation Admoinistration, Office of Environmental Quality, Impact of noise on people (Washington, D.C., 1977): 4.

8. Ibid., 2 .

9. Paul D. Schomer, A survey of community attitudes towards noise near a general aviation airport, The Journal of the Acoustical Society of America 74, 6 (December 1983): 1778.

10. Malcolm D. Arnoult, et. al., Annoyingness of aircraft noise in relation to cognitive activity, Perceptual and Motor Skills 63, 2 (1986): 616.

11. CLM/Systems, Inc., Airports and their environment: A guide to environmental planning, 179. 


\section{CHAPTER FOUR INVENTORY AND EXISTING CONDITIONS}

In this chapter, the existing conditions of Quonset State Airport (QSA) and the Towns of North Kingstown and Jamestown are examined. The discussion on QSA includes the history of its development, its curren! role within the state airport system, a description of the airport facilities, selected annual indicators which show the level of activity at the airport, and existing noise abatement procedures. The two towns are discussed in terms of current land use, zoning, and housing and population. The current impact of noise on the community is also assessed.

\section{Quonset State Airport}

QSA is the former U.S. Naval Air Station, Quonset Point, and now serves the Rhode Island National Guard and general aviation users. It has been slow to develop since the State took ownership in 1974 , although its facilities are superior to those of the other general aviation airports in Rhode Island.

\section{The History of Quonset Point and Quonset Naval Air Station}

The area known as Quonset Point in North Kingstown, Rhode Island has a colorful military history. The property was first used by the State Militia at the end of the nineteenth century, was then used by the U.S. Navy during the Second World War, and was turned over to the State again in 1974. 
The State of Rhode Island acquired the property in 1893 as a campsite for the State Militia and con tinued to use the grounds for that purpose for 47 years. In 1940 the 754 -acre site was sold to the federal government for one million dollars.' The development that took place on that site in the following year is staggering. The \$24 million military complex was commissioned as Quonset Point Naval Air Station in 1941. The massive construction project employed 11,000 civilian workers who completed the two to three year venture in one year. ${ }^{2}$

The facilities necessary to carry out the mission of a Naval Air Station included a deep water port for ships and aircraft carriers, and an airfield. Nineteen million cubic yards of sand were dredged from Narragansett Bay and used to fill in the bay side of the property. The total amount of land gained by filling was 400 acres. Four runways for the airport were built on this filled land. Other facilities on the base included airplane and seaplane hangars, control towers, housing for 15,000 soldiers, underground storage for three million gallons of fuel, and an 1172' pier. Quonset Point Naval Air Station has been called "the biggest and toughest, yet most rapidly progressing construction project ever undertaken on the Atlantic coast." ${ }^{3}$

Development continued for several years, but was followed by a period of decline that led to the eventual closure of the facility. In 1944, Quonset Point Naval Air Station became the seat of the Commander of Naval Air Bases, First Naval District. Naval facilities from Bar Harbor, Maine to Groton, Connecticut were included in this district. In 1952, the longest runway was extended from $6000^{\prime}$ to $8000^{\prime}$. Several years later, however, in 1960 Runway $10-28$ (the east-west runway) was closed. Runway 01-19 (the north-south runway) was abandoned in 1973 when the Navy closed the entire base. This base closure was part of a national down- 
sizing of the military.

In 1974 , the property was conveyed back to the State of R hode Island with restrictions on its use. As far as the airport is concerned, there are two types of land, airport land (697 acres) and revenue-generating land (57 acres) to supplement the airport. The following restrictions are placed on the use of the land by the Department of Defense:

- The land is to be used as a public-use airport in safe and serviceable condition;

- the land is not to be used or disposed of for non-airport uses unless FAA approves, and FAA may only approve if the use does not adversely affect the airport;

- the state must protect the runway approaches and prevent obstructions to airspace;

- in a national emergency, the federal government must be allowed exclusive or non-exclusive use;

- if the terms of the deed are not met, the airport will revert to the federal government within sixty days;

- revenues generated and excess to the needs or Quonset State Airport may be used for other state airports; and

- the clear zone off runway end 5 is to be used in a way compatible with that designation. ${ }^{4}$

The emergency takeover restriction mentioned above does not apply to parcels used for nonaeronautical purposes.

Quonset State Airport opened in 1976 with the use of two runways, including the longest one at $8000^{\prime}$. The Rhode Island National Guard relocated to QSA from T.F. Green Airport in 1979. A new control tower that replaced the military one became operational in 
1980. After several years of operating the airport, the Department of Transportation, Division of Airports became the official owner of the airport in 1981. As of 1993, the property came under the jurisdiction of the newly created Airport Corporation within the Rhode Island Port Authority and the Rhode Island Department of Economic Development. An aerial photograph showing the runway configuration and surrounding development appears in Figure 4.1.

\section{The Role of Quonset State Airport within the State Airport System}

The State Airport System consists of six airports: T.F. Green, Quonset, North Central, Newport, Westerly, and Block Island with each serving a unique function within the state. The location of each state airport is shown on a map in Figure 4.2. There are other privately owned airfields that are not included. Generally, T.F. Green is the primary airport and the other five are general aviation airports. It is not within the scope of this study to perform a detailed statistical comparison of all of the airports, but following is a description of their basic functions. The FAA has a system of airport classification that describes the airports traffic, facilities, and service level. Although the entire system is not portrayed here in great detail, relevant terms are defined where they first appear in the text. The number of operations at each airport in 1992 appears in the Airport Data section of this chapter.

T.F. Green State Airport is the primary commercial service airport in the State and serves Rhode Island, southeastern Massachusetts, and southeastern Connecticut with regularly scheduled airline flights. A new terminal designed to accommodate more passengers is in the pipeline. In 1990, there were 128,807 operations (takeoffs and landings), most of which were 


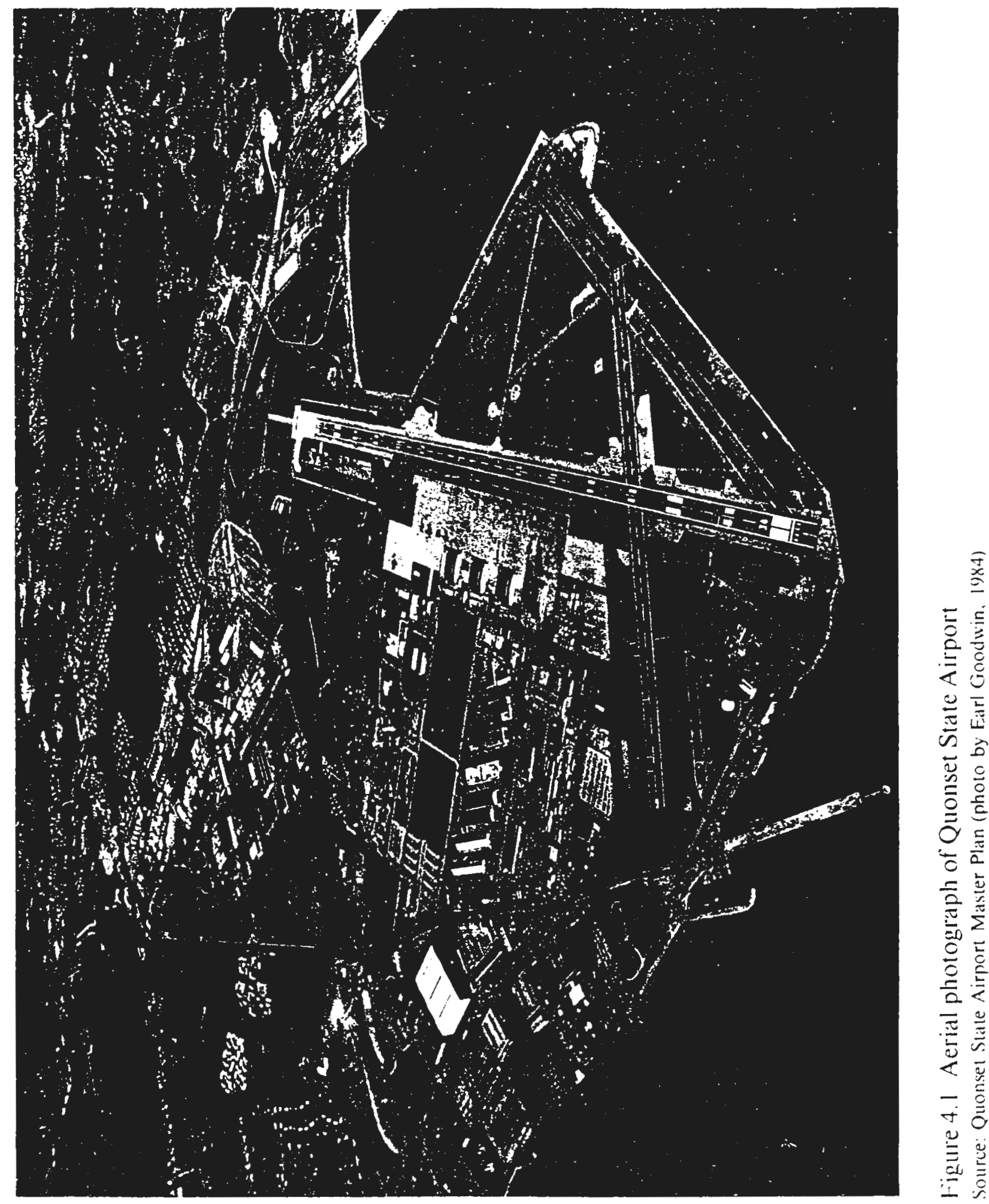




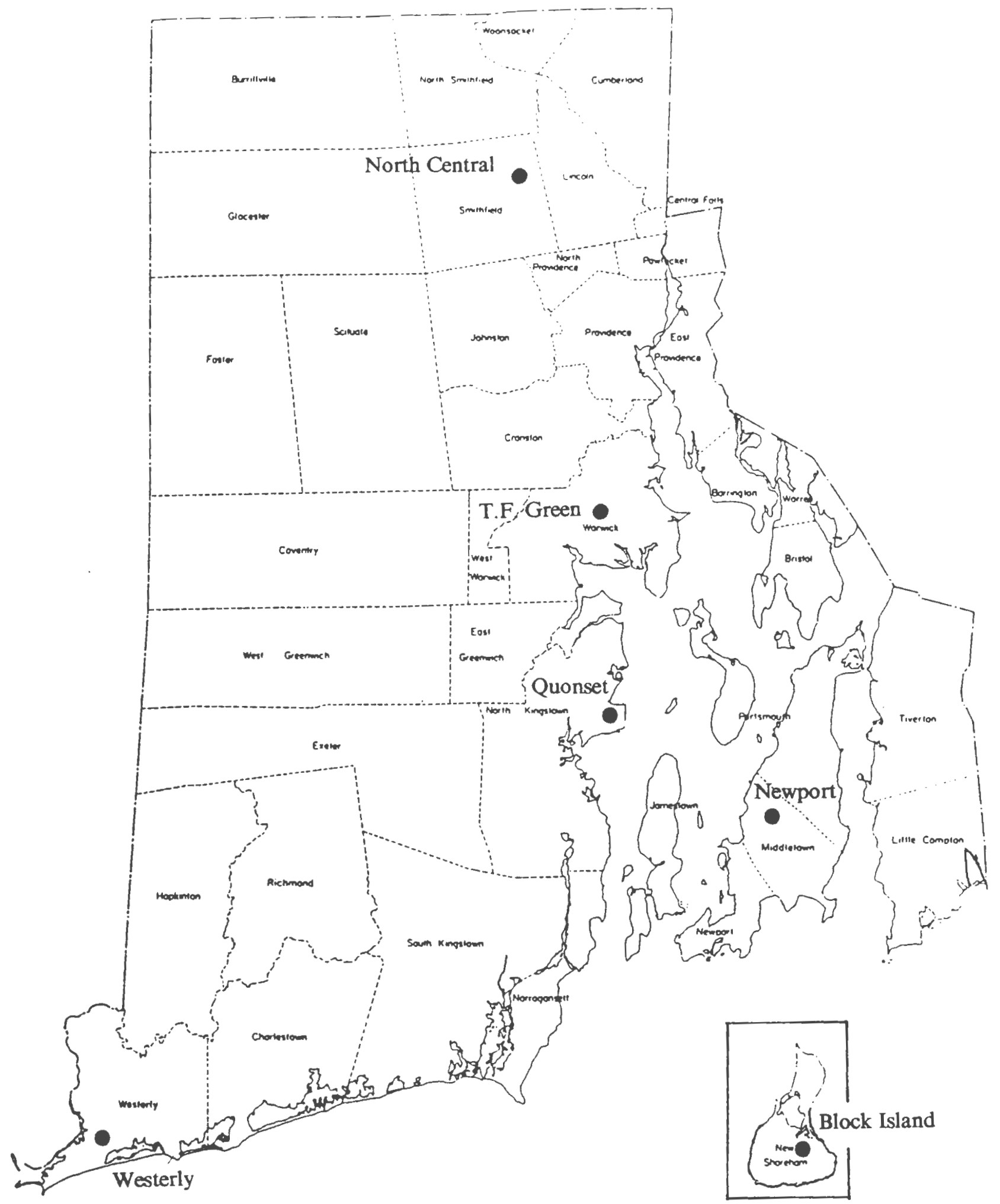

Figure 4.2 Rhode Island State Airports

Source of base map: Rhode Island Department of Administration, Division of Planning 
general aviation operations.' In the national airport plan, T.F. Green is classified as a small hub, which means that it enplanes between 0.05 and 0.25 percent of all national passengers annually. It is a transport utility category airport, meaning that its runways can accommodate all large planes. The busiest markets for commercial flights from T.F. Green are Washington, D.C., Chicago, Philadelphia, Orlando, and New York. ${ }^{\circ}$ Markets are final destinations, not direct flights, and New York is where most connecting flights are made.

North Central State Airport is a reliever to T.F. Green as designated by the FAA. A reliever is intended to absorb excess general aviation traffic from larger airports. It is a general utility airport, meaning that its runways can handle all small planes. It serves the northern Rhode Island area.

Newport State Airport is a basic utility general aviation airport. Its runways can accommodate only 75 percent of small airplanes, and it has the fewest operations in the State. It serves the general aviation needs of the East Bay area.

Block Island State Airport is a vital transportation link to the mainland, especially in emergency situations. It is designated as a commercial service airport, meaning that it receives limited commercial service and enplanes at least 2500 passengers annually. It classified as a basic utility airport with one runway in that category.

Westerly State Airport serves as Block Island's main connection on the mainland. It also is designated as a commercial service airport, but its runways are in the general utility category that can accommodate more types of airplanes than Block Island.

Quonset State Airport is designated by the FAA as a reliever to T.F. Green. T.F. Green 
and Quonset are the only transport utility airports in the State, with Quonset having the longest runway. QSA also has the only other control tower and instrument approach landing system in the State. Another unique feature is that QSA is the home of two units of the Rhode Island National Guard, the Air National Guard and the Army National Guard. Both units are operating under 50-year leases and have made extensive improvements to their facilities. Quonset serves all of the military aviation needs and some of the general aviation needs of the state.

\section{Facilities at Quonset State Airport}

As mentioned above, QSA has the capability to accommodate a much higher level of use than it is presently. The transport utility runways, control tower, and instrument landing system are facilities that the other general aviation airports do not possess.

Runways. Runways are designated by compass headings with the final zero dropped. For example, an east-west runway is called 09-27 when referring to it in a general sense (90 degrees is an easterly heading, and 270 degrees is a westerly heading). It is called Runway 09 if aircraft are taking off or landing from west to east, or Runway 27 from east to west.

QSA has four runways, two of which are operational. Runways 01-19 and 10-28 (the north-south and east-west runways) are closed. R unways 05-23 and 16-34 (northeast-southwest and northwest-southeast) are operational. Runways 01-19, 10-28, and 05-23 are each 4000' feet long; Runway 16-34 at $8000^{\prime}$ long is the longest runway in the state and can accommodate almost any aircraft. The Airport Layout Plan in Figure 4.3 shows the configuration of the 


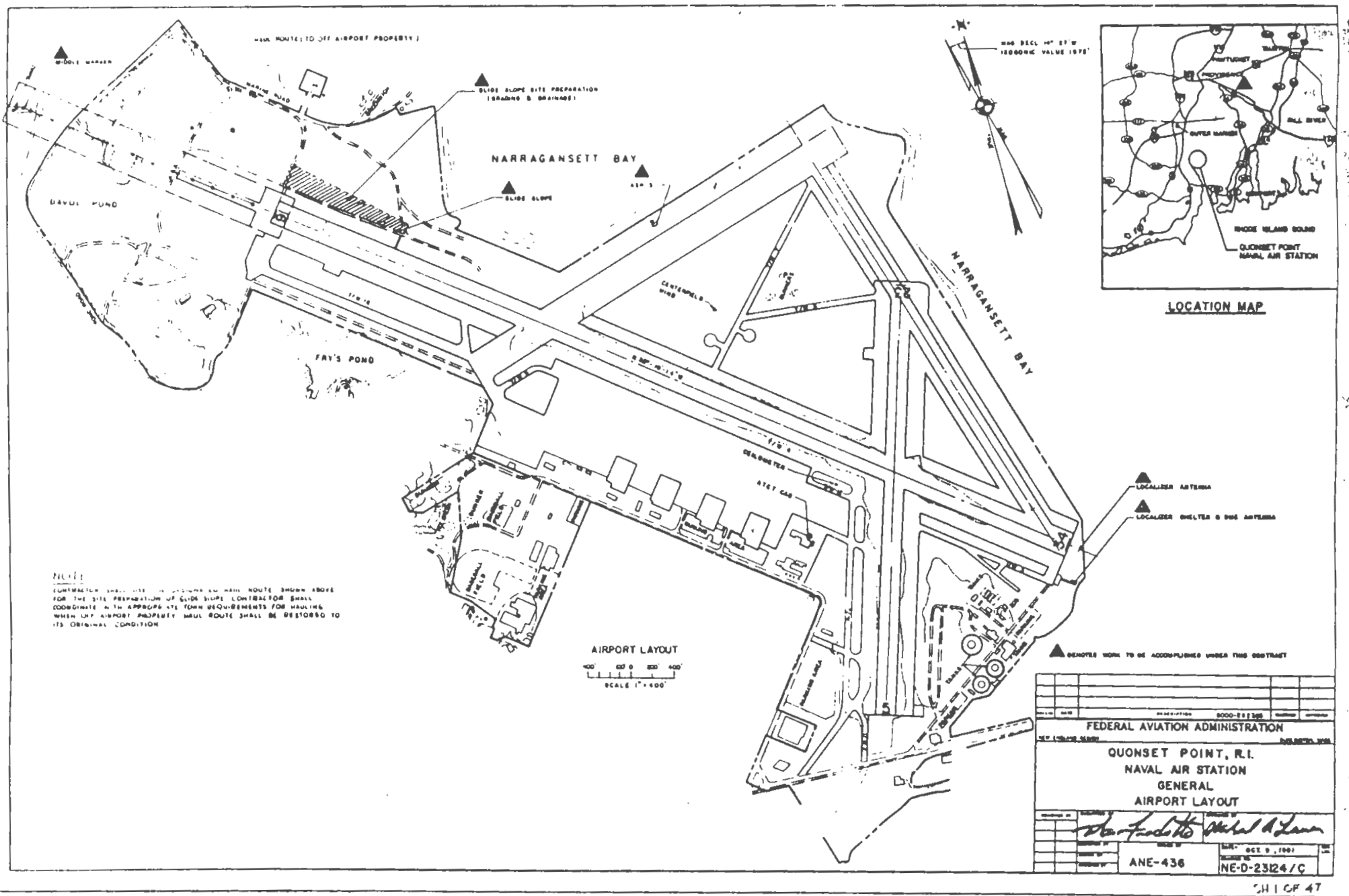

Figure 4.3 Quonset State Airport Layout Plan

Source: Federal Aviation Administration, New England Region 
runways and taxiways and some hangars.

Instrument landing system. (ILS). There are two sets of flight rules, Visual Flight Rules (VFR) and Instrument Flight Rules (IFR). VFR requirecertain minimum standards of weather such as cloud cover, ceiling, and visibility for aircraft operation. IFR allow instrumentequipped aircraft to takeoff and land in much worse weather with only very heavy fog or precipitation interfering with IFR flights. Runway 16 is equipped with an instrument landing system that provides a pilot with exact descent and alignment information. ${ }^{7}$ This allows the airport to be used for a greater percentage of time than the State's other general airports.

Control tower. The tower at QSA is operated by the Air National Guard from 7 a.m. to 11 p.m. This means that the airspace around the airport is controlled, and aircraft wishing to enter the airspace must obtain permission from the tower. An airport must have a control tower to safely handle a high traffic levels. A UNICOM radio service that advises pilots about weather conditions and airport services is operated 24 hours per day by the RIDOT Division of Airports.

Hangars. There are nine hangars at the airport, seven of which are easily identifiable on the aerial photograph shown in Figure 4.1. The National Guard and Electric Boat each use three large hangars and one small one. The remaining hangar is owned by the State and leased to lixed-base operators (FBO). ${ }^{8}$ FBO's and services available at QSA are described in the next section. 


\section{Tenants and Fixed-Base Operators}

Tenants that utilize the airport fall into two categories, civilian and military. Civilian users are referred to as fixed-base operators $(\mathrm{FBO})$ and are aviation-related businesses. Military tenants include aviation units of the National Guard. The following tenants and FBO's reside at QSA:

Rhode Island Army National Guard, Army Aviation Support Facility and 1/126 Attack Helicopter Battalion; this unit has 38 based aircraft ( 37 helicopters and one light airplane)"

Rhode Island Air National Guard, 143rd Tactical Airlift Group; this unit has 8 based aircraft (large cargo planes) ${ }^{10}$

Quonset Aircraft Services - Maintenance facility in the hangar, with no based aircraft

Quonset Flight Center - Flight School with one based airplane; this company has other aircraft based at a private airport in Richmond, Rhode Island

Fantasy Air Fuel Company - Fuel vendor with no based aircraft

\section{Airport Data}

The level of use at an airport can be described in a number of ways: number of operations (takeoffs and landings), number of passengers, pounds of cargo, and number of based aircraft. Compiling operational data at QSA is complicated by the use of different definitions by the State and the FAA and by inconsistencies in data collection. In the case of QSA, it is appropriate to further separate each indicator in to civilian and military components. The figures that appear below are the most recent and most complete available data. Although the State began operating the airport in 1976, data is presented only from 1980 for two reasons: 
1) The control tower opened in 1980 and previous data collection through radio contact is not as reliable, and 2) the National Guard units moved from T.F. Green in 1979, and figures are abnormally high for that year.

The number of operations is the most accurate measure of airport activity as far as noise is concerned. An operation in Rhode Island data collection is a takeoff or a landing, but the FAA also includes touch-and-go movements in operations data, therefore showing greater activity at all airports. The FAA separates operations into itinerant and local operations. Itinerant movements are aircraft based elsewhere, and local movements are aircraft based at that airport." Data can be further disaggregated by type of aircraft: air carrier, commercial, general aviation, and military. Rhode Island data is similar to the FAA's, except that the terms "transient and based" are substituted for "itinerant and local." ${ }^{12}$ For the purposes of this study, data on operations is obtained from the State of Rhode Island and divided only into military and civilian components. Transient and based operations are not presented because it does not contribute to the understanding of a noise problem; the origin of a movement does not impact the amount of noise that is generated. Table 4.1 and Figure 4.4 are the annual operations at QSA since $1980 .^{13}$

Figure 4.4 shows graphically the level of operations for the past thirteen years. The high number in 1980 may be a residual effect of the National Guard's transfer from T.F. Green in 1979. and the shift in data collection methods. From 1981 to 1991, operations have remained fairly stable with a low of 29,209 in 1985 and a three-year high period of approximately 42,000 
Figure 4.4 Annual Operations, 1980-1991

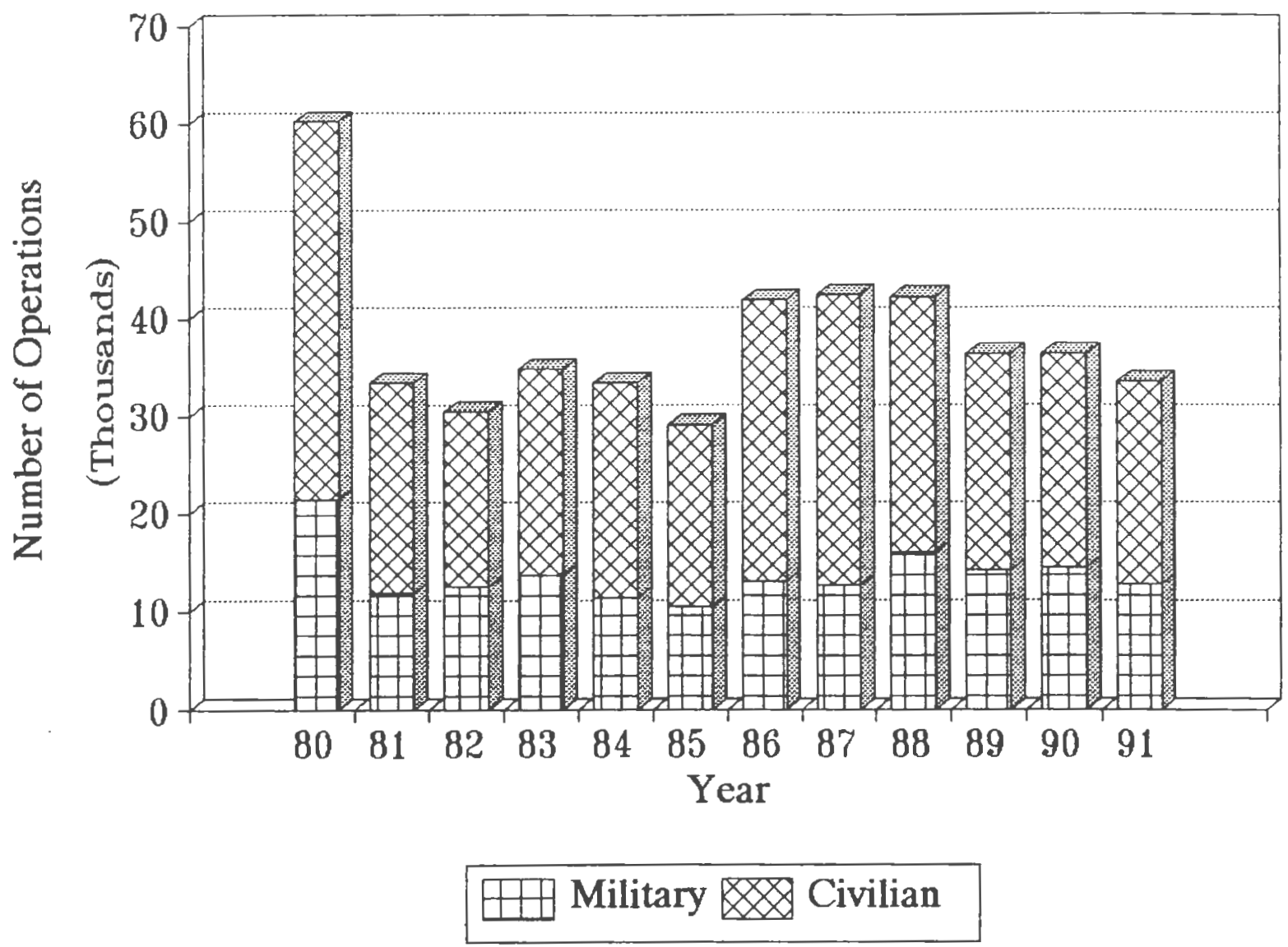

Source of data: Rhode Island Department of Transportation, Division of Airports 
Table 4.1 Quonset State Airport, Annual Operations, 1980-1991

\begin{tabular}{|c|c|c|c|}
\hline Year & Military (percent of total) & Civilian (percent of total) & Total \\
\hline \hline 1980 & $21474(36 \%)$ & $38797(64 \%)$ & 60271 \\
\hline 1981 & $11852(35 \%)$ & $21547(65 \%)$ & 33399 \\
\hline 1982 & $12530(41 \%)$ & $18055(59 \%)$ & 30585 \\
\hline 1983 & $13766(39 \%)$ & $21125(61 \%)$ & 34891 \\
\hline 1984 & $11325(34 \%)$ & $22066(66 \%)$ & 33391 \\
\hline 1985 & $10485(36 \%)$ & $18724(64 \%)$ & 29209 \\
\hline 1986 & $13080(31 \%)$ & $28956(69 \%)$ & 42036 \\
\hline 1987 & $12616(30 \%)$ & $29862(70 \%)$ & 42478 \\
\hline 1988 & $16103(38 \%)$ & $26289(62 \%)$ & 42392 \\
\hline 1989 & $14150(39 \%)$ & $22215(61 \%)$ & 36365 \\
\hline 1990 & $14519(40 \%)$ & $21861(60 \%)$ & 36380 \\
\hline 1991 & $12785(38 \%)$ & $20802(62 \%)$ & 33587 \\
\hline
\end{tabular}

Source of data: Rhode Island Department of Transportation, Division of Airports.

operations from 1986 to 1988 . The percentage of operations attributed to military aircraft has remained fairly constant in the range of 30 to 42 percent.

To compare QSA to the other five state airports, 1992 total operations are as follows:

$\begin{array}{ll}\text { T.F. Green } & 137,490 \\ \text { North Central } & 90,216 \\ \text { Block Island } & 25,302 \\ \text { Quonset } & 25,189 \\ \text { Westerly } & 22,987 \\ \text { Newport } & 17,736\end{array}$

T.F. Green and North Central are by far the busiest; QSA has the fourth highest number of 
operations. This is the first time since 1988 that QSA has fallen to fourth place; usually Block Island is fourth. ${ }^{14}$

Passengers and cargo are also indicators of airport activity, but fluctuate more from year to year. They are more indicative of types of aircraft, but less indicative of noise. Annual data for passengers and cargo (military and civilian) are shown in Table 4.2.

Table 4.2 Quonset State Airport, Annual Passengers and Cargo, 1980-1991

\begin{tabular}{||c||c|c|c||c|c|c||}
\hline \multirow{2}{*}{ Year } & \multicolumn{3}{|c|}{ Passengers } & \multicolumn{3}{c|}{ Cargo (pounds) } \\
\cline { 2 - 7 } & Military & Civilian & Total & Military & Civilian & Total \\
\hline \hline 1980 & 10147 & 10323 & 20470 & 66365 & 55925 & 122290 \\
\hline 1981 & 11342 & 5185 & 16527 & 103620 & 68500 & 172120 \\
\hline 1982 & 9543 & 4903 & 14446 & 230808 & 135000 & 365808 \\
\hline 1983 & 10791 & 10979 & 21770 & 178060 & 25000 & 203060 \\
\hline 1984 & 2353 & 16628 & 18981 & 96660 & 47139 & 143799 \\
\hline 1985 & 4646 & 16177 & 20823 & 473300 & 1600 & 474900 \\
\hline 1986 & 3581 & 17500 & 21081 & 382000 & 2530 & 384530 \\
\hline 1987 & 6671 & 22060 & 28731 & 364500 & 1920 & 366420 \\
\hline 1988 & 2874 & 21097 & 23971 & 235000 & 31140 & 266140 \\
\hline 1989 & 4571 & 10956 & 15527 & 245348 & 0 & 245348 \\
\hline 1990 & 19310 & 10468 & 29778 & 244973 & 0 & 244973 \\
\hline 1991 & 16380 & 11453 & 27833 & 228063 & 1550 & 229613 \\
\hline \hline
\end{tabular}

Source of data: Rhode Island Department of Transportation, Division of Airports.

Figure 4.5 portrays the passenger data in graphic form. The highest total number of passengers 
Figure 4.5 Annual Passengers 1980-1991

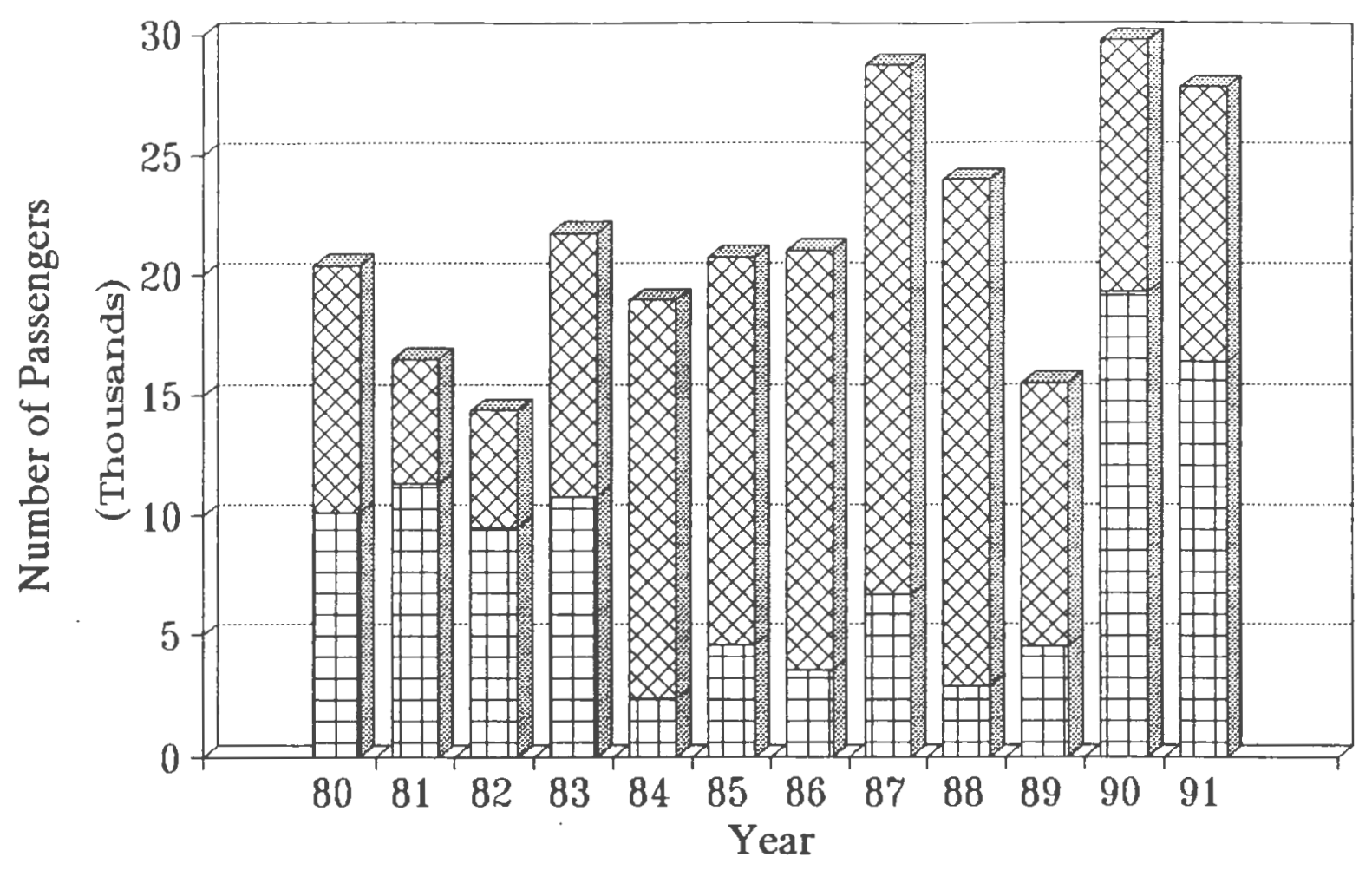

\section{$\boxplus$ Military Civilian}

Source of data: Rhode Island Department of Transportation, Division of Airports 
$(29,788)$ and the second lowest $(15,527)$ occurred within the space of two years, 1990 and 1989.

The period from 1982 to 1987 shows a general increase in civilian passengers from approximately 5000 to 22,000; this signifies an increase in general aviation. That same number drops to around 11,000 again in 1989 through 1991 which may be attributed to a poor economy because flying is an expensive hobby. The years of 1990 and 1991 showed a marked increase in military passengers from the preceding six years.

Movement of cargo, as shown in Figure 4.6 has been erratic, but has stabilized in the last four years of the time period. The military had active years in 1985 (also the highest total year), 1986, and 1987. This indicates an increased use of large, heavy planes which are also noisy. In 1982, there was an increase in both civilian and military cargo, but the years of 1983 and 1984 showed very little activity. Cargo shipment in the past few years has hovered around 250,000 pounds, almost exclusively from the military.

Number of based aircraft is an indicator of airport activity, especially based operations. This data, however has not been collected by the state since 1984 . The number of civilian based aircraft remained between 26 and 35 from 1980 to 1984. The current number is 24 civilian airplanes, 9 military airplanes, and 37 military helicopters. ${ }^{15}$

To summarize airport activity over the past thirteen years, cargo has been erratic, but has stabilized in the past four years; the number of passengers has increased; and the number of operations, the most important indicator, has remained steady with the exception of the first year of the time period. As a general aviation and military facility, activity is vulnerable to the economy and to national defense policies. 
Figure 4.6 Annual Cargo, 1980-1991

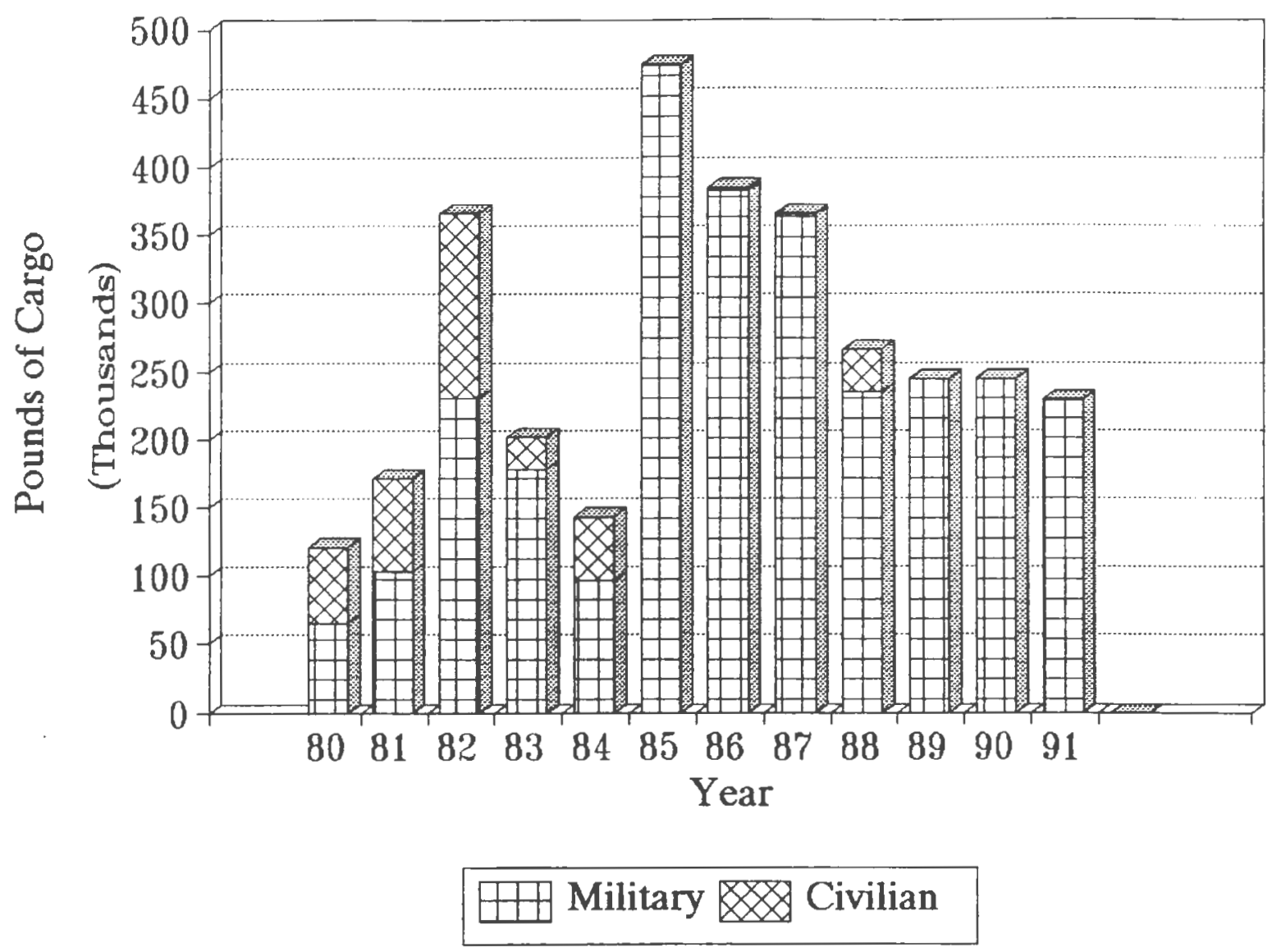

Source of data: Rhode Island Department of Transportation, Division of Airports 


\section{Existing Noise Abatement Measures}

Noise has been recognized by airport users as a community concern. A combination of noise abatement measures from various sources constitute the effort made the airport to maintain a friendly relationship with North Kingstown.

Civilian aircraft at Quonset are generally light propeller-driven planes which are not the major contributors to noise, but there are sporadic operations of business jets. It is a standard practice for pilots to utilize noise abatement measures recommended by the manufacturers and by the FAA, such as the landing and takeoff profile, the engine power settings, and minimum safe altitudes. Flight tracks can be adjusted somewhat to avoid noise sensitive areas. ${ }^{16}$ (Flight tracks map appears later in this chapter in Figure 4.12.) Although these standards and procedures exist, there is no enforcement mechanism.

The two National Guard units follow strict noise abatement practices. In the case of the Army Aviation Support Facility, for example, four sources of noise regulations exist: the FAA, the Army, the Army National Guard, and non-governmental sources such as the Fly Neighborly Guide published by the Helicopter Association International. Whenever different standards for the same procedure exist, pilots abide by whichever one is the most strict. There are also regulations that are peculiar to Quonset, such as high population density "no fly" areas. No fly areas are shown in Figure 4.7; these noise-sensitive areas include Wickford Village and Quidnessett. In other less densely populated areas, minimum altitude limits are $2000^{\prime}$ for certain helicopters and $1500^{\prime}$ for less noisy helicopters. ${ }^{17}$ In these same populated areas, the FAA requires only $1000^{\prime}$ altitude. In unpopulated areas minimum altitude is $500^{\prime} .^{18}$ High altitude 


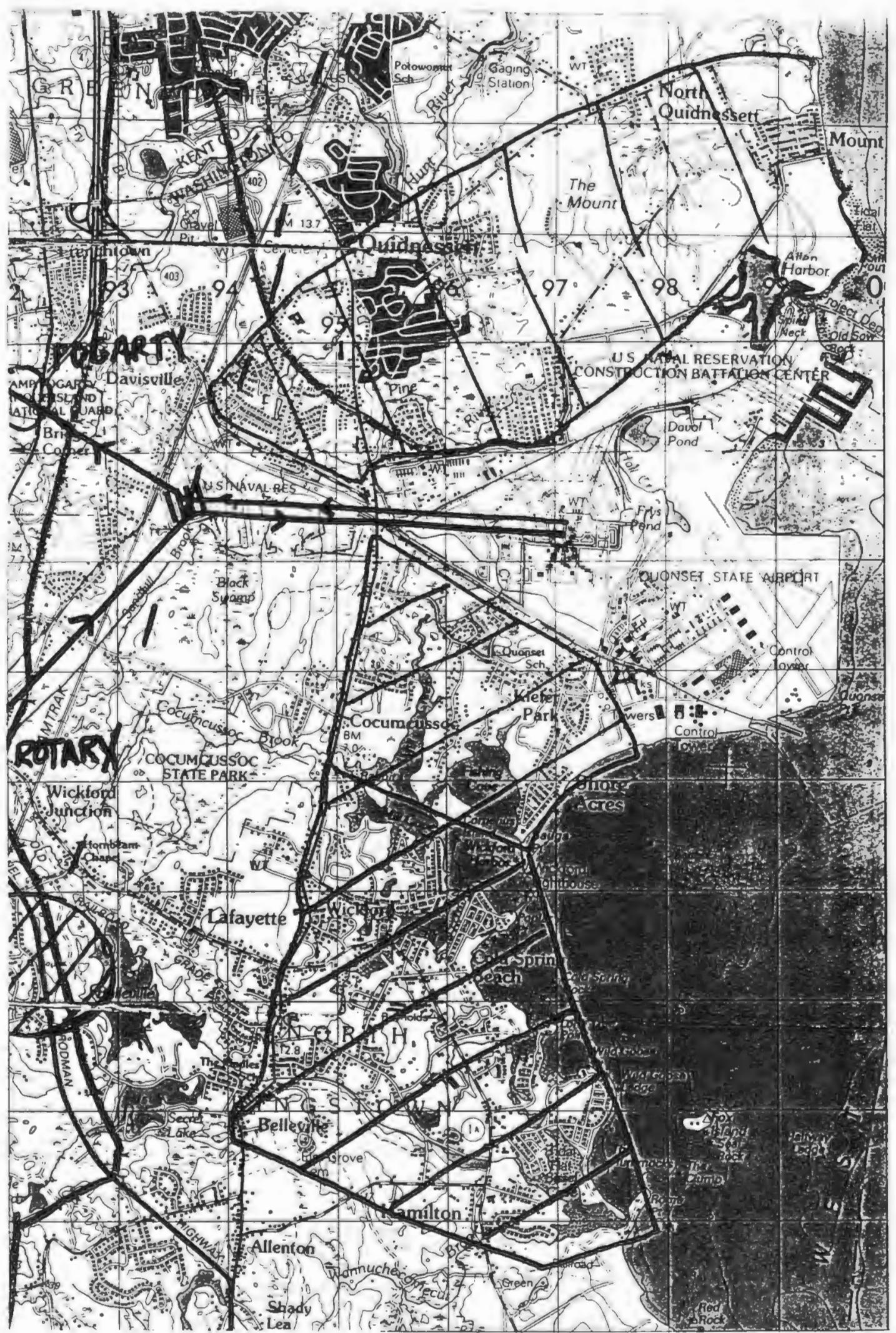

Figure 4.7 North Kingstown "No-Fly" Areas

Source: ILT Brian C. Trapani, Aviator, 1/126 Attack Helicopter Battallion 
approaches and steep glide angles are standard operating procedures. The Army Aviation Support Facility also limits operations to between 7 a.m. and 11 p.m."

The Air National Guard has adopted similar procedures. They observe a 10:30 p.m. curfew and high altitude approaches. They also have a preferential runway system to encourage night over Narragansett Bay rather than over North Kingstown; this includes a required turn over the water to avoid Jamestown. When flight over land is necessary, mixed traffic patterns are utilized to reduce noise exposure in a single concentrated area. Airplane engine run-ups are performed at a mid-field taxiway that directs noise away from residential neighborhoods. The unit conducts flight training and practice takeoffs and landings at another airport. ${ }^{20}$

Noise abatement is a high priority among airport users and regulators. All available procedural and operational methods have already been implemented, and continued sensitivity to the noise issue is expected.

\section{Towns of North Kingstown and Jamestown}

Of the towns and cities around Narragansett Bay, North Kingstown and Jamestown are the most affected by noise generated at and around Quonset State Airport. They are stakeholders in the future use and development of QSA, and their community goals should be considered in the formation of a noise compatibility plan. The State map in Figure 4.2 shows the geographic relationship of the towns surrounding the study area. Although East Greenwich is in close proximity to QSA, it is not included in the study area because of the more severe noise impact it experiences from T.F. Green. 
North Kingstown has a population of 23,861 according to the 1990 census. It is bordered by Warwick and East Greenwich to the north, Exeter to the west, and South Kingstown and Narragansett to the south. Its eastern edge lies on Narragansett Bay. The part of the town included in the study area is east of Route 1 (and portions immediately west) and north of Route 138. The North Kingstown Comprehensive Plan divides the town into seven planning districts. The districts that correspond roughly to the study area are Quidnessett, Coastal Villages (including Wickford), and Quonset Point/Davisville, and are shown in Figure 4.8. All three of these extend beyond the study area boundary somewhat, and other districts have small parts within the study area, but the three planning districts mentioned are a good approximation of the population and activity of the study area.

The island community of Jamestown, with a population of 5800 , is situated in Narragansett Bay with North Kingstown and Narragansett to its west, and Newport to its east. The northern portion of Jamestown is included in the study area, which is the area north of Route 138 and the Jamestown Bridge. The town has four types of land areas that are somewhat like North Kingstown's planning districts. Jamestown Shores (a dense residential area), Rural Residential, and Conservation areas are included in this study; the Village portion of Jamestown is not. The study area is discussed in terms of land use, zoning, and population and housing for both towns.

\section{Land Use}

North Kingstown has a wide variety of land uses within the study area. There are strip 


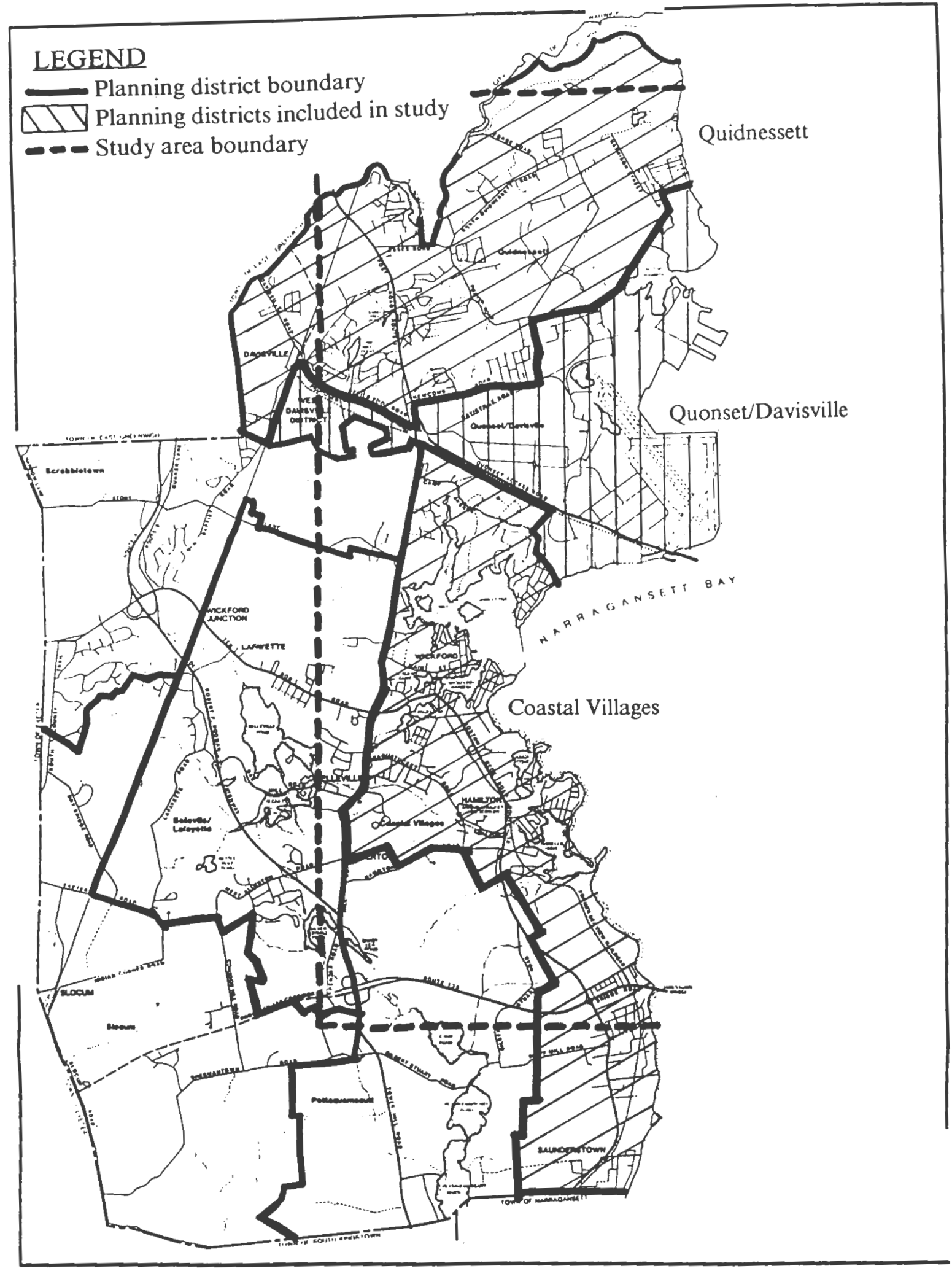

Figure 4.8 North Kingstown Planning Districts Source: North Kingstown Comprehensive Plan 
commercial corridors, industrial sites, open space, all types and densities of housing, a small mixed-use village, and undeveloped land. Jamestown is primarily low and medium density residential with open space and undeveloped land. Figure 4.9 shows land use in both towns. In this map residential land is not differentiated by density of development. ${ }^{21}$

The two towns use different categories of land use within their own comprehensive plans. Table 4.3 shows the classifications of land uses utilized in this study and the corresponding ones used by the towns. Also shown is the approximate percentage of land area that cach usc occupies in each town.

Table 4.3 Existing Land Use Categories

\begin{tabular}{||c||c|c||c|c||}
\hline \multirow{2}{*}{ Study area } & \multicolumn{2}{|c|}{ North Kingstown } & \multicolumn{2}{c||}{ Jamestown } \\
\cline { 2 - 5 } & Land use category & percent & Land use category & percent \\
\hline \hline Residential & Residential & 30 & $\begin{array}{c}\text { All catcgories of } \\
\text { residential }\end{array}$ & 60 \\
\hline Commercial & Commercial & 5 & N/A & 0 \\
\hline Institutional/Public & Public/semi-public & 5 & N/A & 0 \\
\hline Industrial & Industrial & 10 & N/A & 0 \\
\hline Transportation/Utility & $\begin{array}{c}\text { Industrial; } \\
\text { public/semi-public }\end{array}$ & 5 & N/A & 0 \\
\hline Open space & $\begin{array}{c}\text { Park/open space; } \\
\text { agricultural: } \\
\text { public/semi-public }\end{array}$ & 10 & $\begin{array}{c}\text { Agricultural; wetland; } \\
\text { conservation/parkland }\end{array}$ & 10 \\
\hline Undeveloped land & 35 & Forest and brushland & 30 \\
\hline Undeveloped land & \begin{tabular}{c} 
Und \\
\hline
\end{tabular}
\end{tabular}

Source: Land use obtained from Comprehensive Plans of each town.

The two predominant uses in both towns are residential and undeveloped land. 


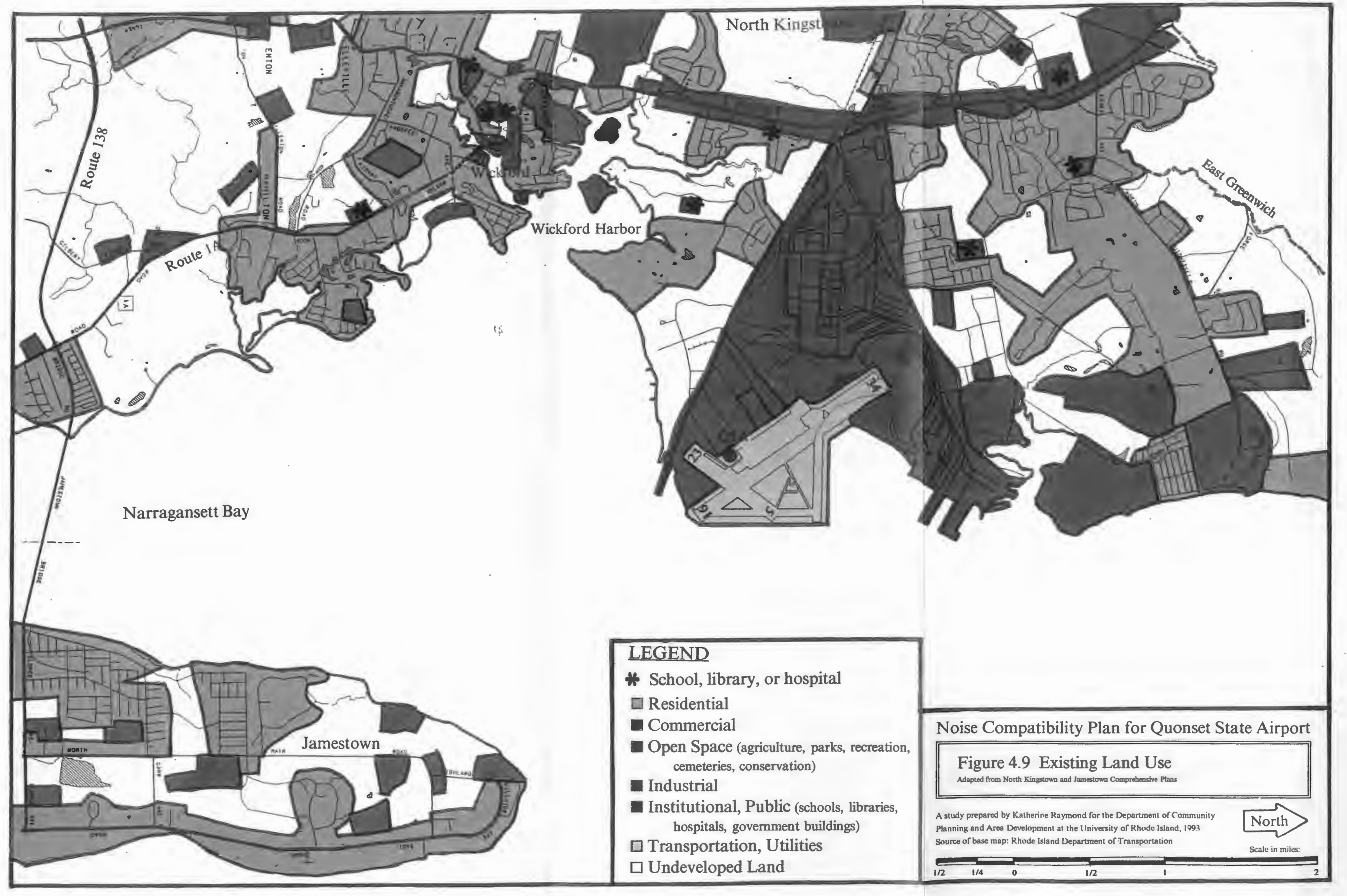


Residential areas are the most sensitive to noise. Other noise sensitive areas include libraries, schools, and health care facilities; there are ten of these in the study area, all of which arc in North Kingstown. There is one library in Wickford, one hospital on the Post Road near Mill Cove, and the rest are schools. The most significant finding of this land use study is the existence of large parcels of undeveloped land in both towns. Land use planning is an effective means to control the future use of this land in order to prevent possible serious noise problems. This is a luxury that urban landlocked airports like T.F. Green do not have.

Quonset State Airport is ideally situated as far as airport noise is concerned. The area immediately adjacent to the airport is industrial, open space or water. However, the land extending beyond the ends of the runways are typically the areas that experience noise from the airport. One mile northeast of Runway 34 is a large residential area. Historically, most noise complaints directed toward QSA have come from the Newcombe Road neighborhood in this area. ${ }^{22}$ Quidnessett and Forest Park Elementary Schools are noise-sensitive uses that are in the vicinity as well. Two miles southwest of Runway 23 is Wickford Village and the coastal residential areas. Southeast of Runway 16, two miles away, is northwest Jamestown and Jamestown Shores. There is nothing northeast of Runway 05; Prudence Island which contains an Esturine Sanctuary and is very sparsely populated is five miles away. Because of the undeveloped land that exists in both towns beyond the ends of Runway 16-34, land use planning can be effective tool to mitigate airport noise. 
Zoning

Zoning is the legal mechanism through which land use plans are implemented. A zoning ordinance dictates to property owners what types of structures can be built and how the land can be used. The state has the power to overrule local zoning ordinances in the case of "height and hazard zones" around airports. Otherwise, the towns generally have control over the land within their borders. Zoning is one of the options available to prevent incompatible development near airports.

Zoning is different in the two towns as is land use. North Kingstown has 29 different zones: 16 residential, 9 business, 3 ind ustrial 1 historic, and 1 open space/public use. Jamestown has 10 zones: 6 types of residential, 3 types of commercial, and 1 open space. The zoning categories used in this study are listed in Table 4.4 along with the corresponding zones from each town. The approximate percentage of land that each zone occupies in the study area is also given. Zones are described within the table, and notes to the table elaborate further on the specialized zones used in North Kingstown. The zoning map appears in Figure 4.10.

Jamestown is zoned entirely residential. Moderate density zoning exists where there is already a dense neighborhood. Low (and very low) density zoning exists everywhere else. This is a strategy used by the town to protect watershed areas and achieve a rural environment. North Kingstown is zoned 65 percent residential in the study area, with equal amounts of high and low density and a lesser amount of moderate density. The town has maintained open space/public land and industrial zoning immediately surrounding the airport. However, land that extends beyond Runways 34 and 23 is zoned moderate and high density residential. 


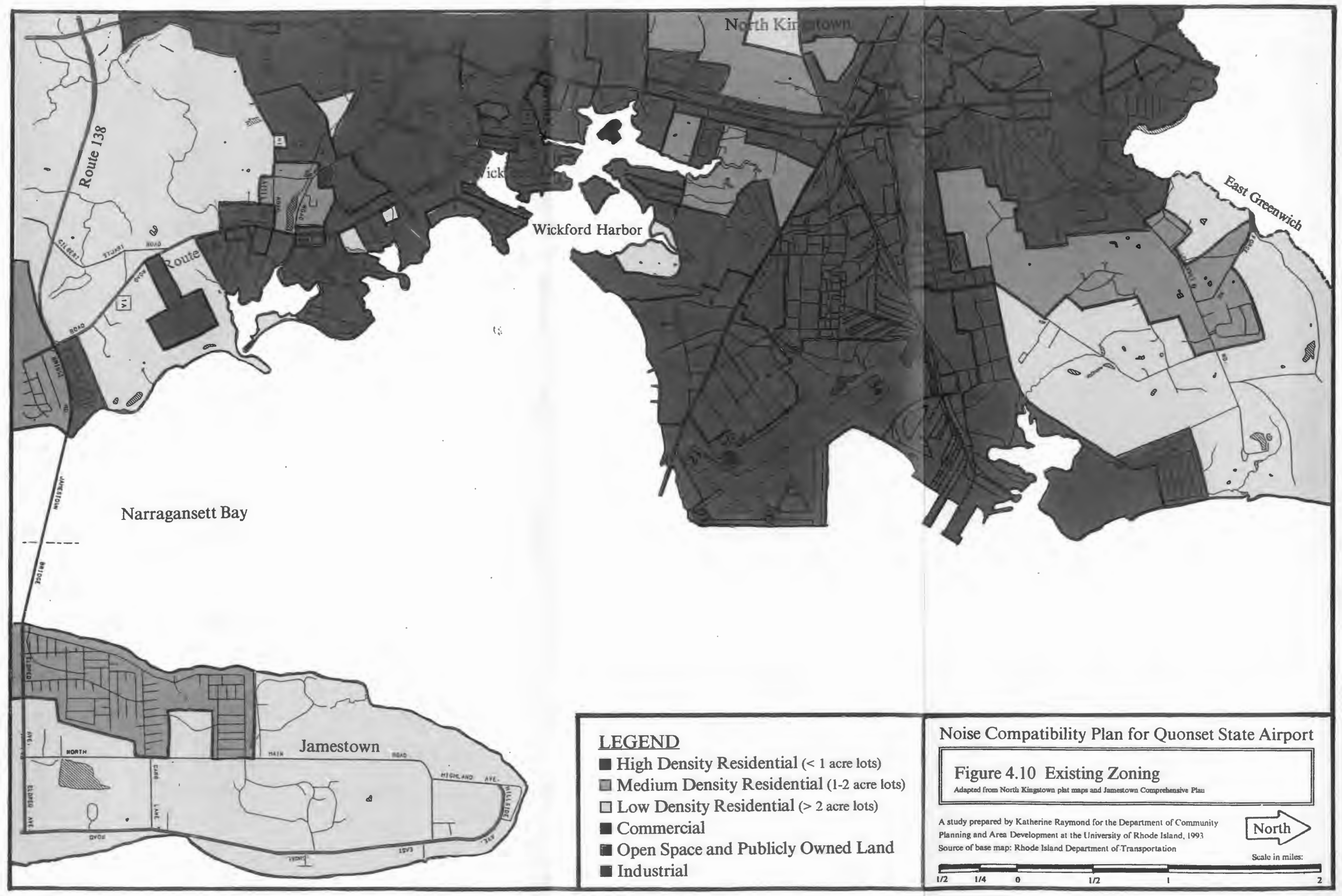


Table 4.4 Existing Zoning Categories

\begin{tabular}{|c|c|c|c|c|}
\hline \multirow[t]{2}{*}{ Study area } & \multicolumn{2}{|l|}{ North Kingstown } & \multicolumn{2}{|l|}{ Jamestown } \\
\hline & Zoning categories & percent & Zoning categories & percent \\
\hline $\begin{array}{l}\text { High density } \\
\text { residential }\end{array}$ & $\begin{array}{l}\text { All types of village residential' } \\
(20,000 \mathrm{SF} \text { lots, minimum); } \\
\text { multi-family residential }\end{array}$ & 25 & $\mathrm{~N} / \mathrm{A}$ & 0 \\
\hline $\begin{array}{l}\text { Moderate } \\
\text { density } \\
\text { residential }\end{array}$ & $\begin{array}{l}\text { All types of neighborhood } \\
\text { residential } \\
(40,(000) \text { SF lots, minimum) }\end{array}$ & 15 & $\begin{array}{l}\text { Residential } 40 \\
(40,000 \mathrm{SF} \text { lots, } \\
\text { minimum) }\end{array}$ & 20 \\
\hline $\begin{array}{l}\text { Low density } \\
\text { residential }\end{array}$ & $\begin{array}{l}\text { All types of rural residential } \\
\text { (80,(00) SF lots, minimum); } \\
\text { Residential cluster or } \\
\text { compound/open space; } \\
\text { Pojac Point residential }\end{array}$ & 25 & $\begin{array}{l}\text { Rural residential } 80 \\
(80,000) \mathrm{SF} \text { lots } \\
\text { ninimum }) \\
\text { Rural residential } 200 \\
(200,000 \mathrm{SF} \text { lots, } \\
\text { minimum) }\end{array}$ & 80 \\
\hline Commercial & $\begin{array}{l}\text { Waterfront business; } \\
\text { neighborhood business; heavy } \\
\text { husiness; general business }\end{array}$ & 5 & N/A & 0 \\
\hline Industrial & Industrial; development district & 15 & N/A & 0 \\
\hline Open space & Open space/public land & 15 & $\mathrm{~N} / \mathrm{A}$ & 0 \\
\hline
\end{tabular}

Source: Zoning obtained from Jamestown Comprehensive Plan and North Kingstown plat maps.

Notes:

1. There are 3 village residential zones: Village Residential, Village Residential Cluster, and Village Residential Compound. Cluster and compound zones require a 10 acre minimum lot.

2. The same cluster and compound zones exist for neighborhood residential.

3. The same cluster and compound zones exist for rural residential.

4. Pojac Point is in the northeast corner of North Kingstown. All lots must be at least 5 acres. Cluster and compound zones also exist in Pojac Point.

5. All four business zones have corresponding limited use zones (e.g. Waterfront Business Limited Use) which are included in the commercial category. 


\section{Population and Housing Units}

Housing and population data are used to get a more accurate assessment of the number of impacted or at risk households in the study area. The average household in North Kingstown contains 2.70 people according to the 1990 census. $^{22}$ As stated previously in this chapter, the three planning districts of Coastal Villages, Quidnessett, and Quonset Point/Davisville in North Kingstown will be used for this analysis. In Jamestown, plat numbers $1,2,3,4,5,15$, and 16 will be used; these plats correspond exactly to the study area. Average household size in Jamestown is $2.81 .^{24}$ Table 4.5 shows the population and number of housing units in each planning district as well as the percentages of each planning district in relation to the town. There are sub-totals for each town and totals for the two towns combined.

The study area in North Kingstown contains 18,611 residents, or 78 percent of the Town's total population, and 70 percent of the housing units. This indicates that there are more persons per household, and likely and more children. Northem Jamestown has 2252 residents, or 39 percent of that Town's population. The whole study area contains 70 percent, or 20,863 people, of the total population of both towns combined, which is 29,611 people.

\section{Noise Contours and Flight Tracks}

To complete the discussion on existing conditions, it is important to include the current interaction between the airport and its surrounding community. To accomplish this, the interaction is described in terms of the existing noise contour and the flight tracks of the aircraft over the communities. The airport obviously has an economic impact as well. In the mid 
Table 4.5 Population and Housing Units, 1990

\begin{tabular}{|c|c|c|c|c|}
\hline \multirow[t]{2}{*}{ District/plat } & \multicolumn{2}{|c|}{ Population } & \multicolumn{2}{|c|}{ Housing units } \\
\hline & Number & Percent of town & Number & Percent of town \\
\hline \multicolumn{5}{|c|}{ North Kingstown } \\
\hline Coastal Villages & 7874 & 33 & 2877 & 29 \\
\hline Quidnessett & 9783 & 41 & 3623 & 37 \\
\hline Quonset/Davisville & 954 & 4 & 353 & 4 \\
\hline Sub-total & 18,611 & 78 & 6853 & 70 \\
\hline Remaining in town & 5250 & 22 & 2997 & 30 \\
\hline Total in town & 23,861 & 100 & 9850 & 100 \\
\hline \multicolumn{5}{|c|}{ Jamestown } \\
\hline 1 & 215 & 4 & 81 & 4 \\
\hline 2 & 300 & 5 & 112 & 5 \\
\hline 3 & 562 & 10 & 211 & 10 \\
\hline 4 & 194 & 3 & 72 & 3 \\
\hline 5 & 403 & 7 & 1.51 & 7 \\
\hline 15 & 374 & 6 & 140 & 6 \\
\hline 16 & 204 & 4 & 76 & 4 \\
\hline Sub-total & 2252 & 39 & 843 & 39 \\
\hline Remaining in town & 3548 & 61 & 1218 & 61 \\
\hline Total in town & 5800 & 100 & 2061 & 100 \\
\hline \multicolumn{5}{|c|}{ Total of both towns } \\
\hline Total study area & 20,863 & 70 & 7696 & 67 \\
\hline Remaining & 8798 & 30 & 4215 & 33 \\
\hline $\begin{array}{c}\text { Total of both } \\
\text { towns }\end{array}$ & 29,661 & 100 & 11,911 & 100 \\
\hline
\end{tabular}

Source: Data obtained from the Comprehensive Plans of both towns. 
1980 's, the airport contributed over $\$ 35$ million to the local economy, primarily through National Guard payroll. ${ }^{25}$ It is, however, beyond the scope of this study to assess the full economic impact of QSA.

\section{Noise Contour}

Noise contours are levels of equal sound from a single source which look like topographical lines when drawn on a map. The last noise study at QSA was completed in the mid 1980's using 1982 flight data. ${ }^{26}$ In that year, there were 30,585 total operations at QSA. This is equivalent to the current level of use $(33,587$ operations in 1991$)$, so the noise contour map completed as part of that study is considered valid for the purposes of this study. The contours, or noise footprints, are shown in Figure 4.11 . Normally, only 65,70 , and $75 \mathrm{~L}_{\mathrm{dn}}$ lines are drawn but even the $60 \mathrm{~L}_{\mathrm{dn}}$ line is shown here. The shape reflects the fact that most operations are on Runway 16-34. Because total number of operations is low, the contour lines barely extend beyond the end of each runway. $L_{d n}$ is the average day/night sound level, a measurement that is adjusted for the frequency and for the time of day that events occur. This is vastly different from a noise contour of a single event, measured in decibels, not $\mathrm{L}_{\mathrm{d}}$. In the

situation of a C-130 27 taking off from Runway 34 , the $75 \mathrm{~L}_{\mathrm{dn}}$ extends to Quidnessett Road which is one mile away. This is also shown in Figure 4.11. Although the frequency of these events is low, ${ }^{28}$ they have a widespread impact. 


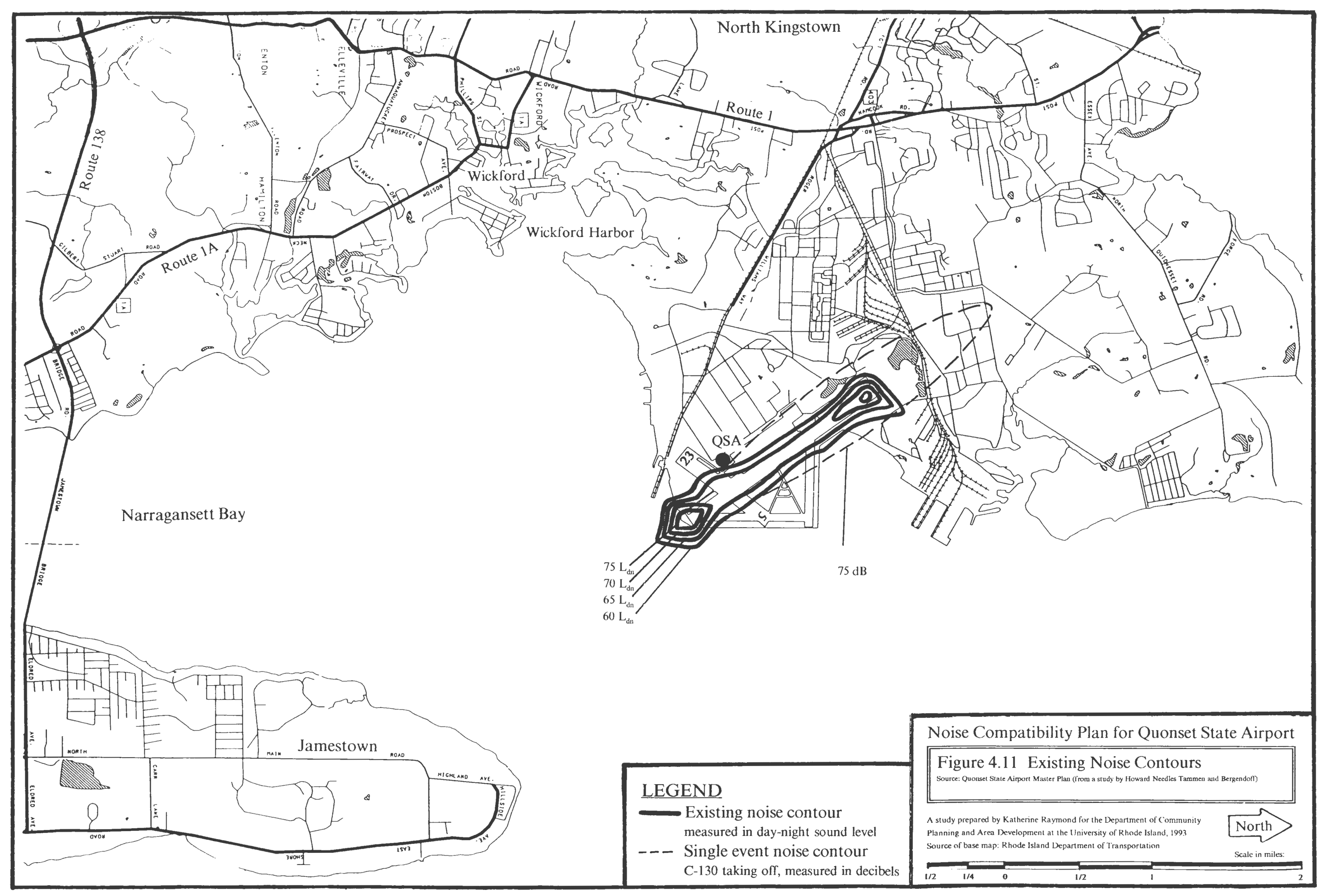




\section{Flight Tracks}

The path or route an aircraft takes that is superimposed on a map is a flight track. They vary according to the purpose of a flight (e.g. touch-and-go), the destination of a flight, and the wind conditions. For example, an aircraft may enter the area from the northwest, fly past the airport, turn around, and land on Runway 34 . The route taken by an aircraft relative to existing land use can impact the noise exposure of the community. Figure 4.12 shows the flight tracks of light airplanes, heavy airplanes, and helicopters as well as the direction of the movement. Runway 05-23 is used only by light aircraft which tend to be less noisy. Runway 16-34 is used by large military aircraft, so their flight tracks are of more importance in a noise study. As can be seen from the map, there are many different flight tracks because some aircraft are able to make sharper turns than others. It can also be seen that some flight tracks pass directly over residential areas.

Landing an airplane is a more difficult maneuver than a takeoff, and as a result, there is less flexibility in altering landing patterns than there is in adjusting takeoff patterns. Large aircraft landing on Runway 16-34 have limited ability to maneuver around residential areas. It is possible, however, to execute a slight turn that can be used to avoid flying directly over Jamestown. Helicopters are the most maneuverable aircraft and can easily avoid residential areas when entering and exiting the airport area; Figure 4.7 shows exactly how helicopters enter and exit the airport area when flying to the west.

The analysis above shows that the airport has had a relatively minor impact as indicated by the $\mathrm{L}_{\mathrm{dn}}$ contours since the departure of the Navy. However, as indicated by the noise 


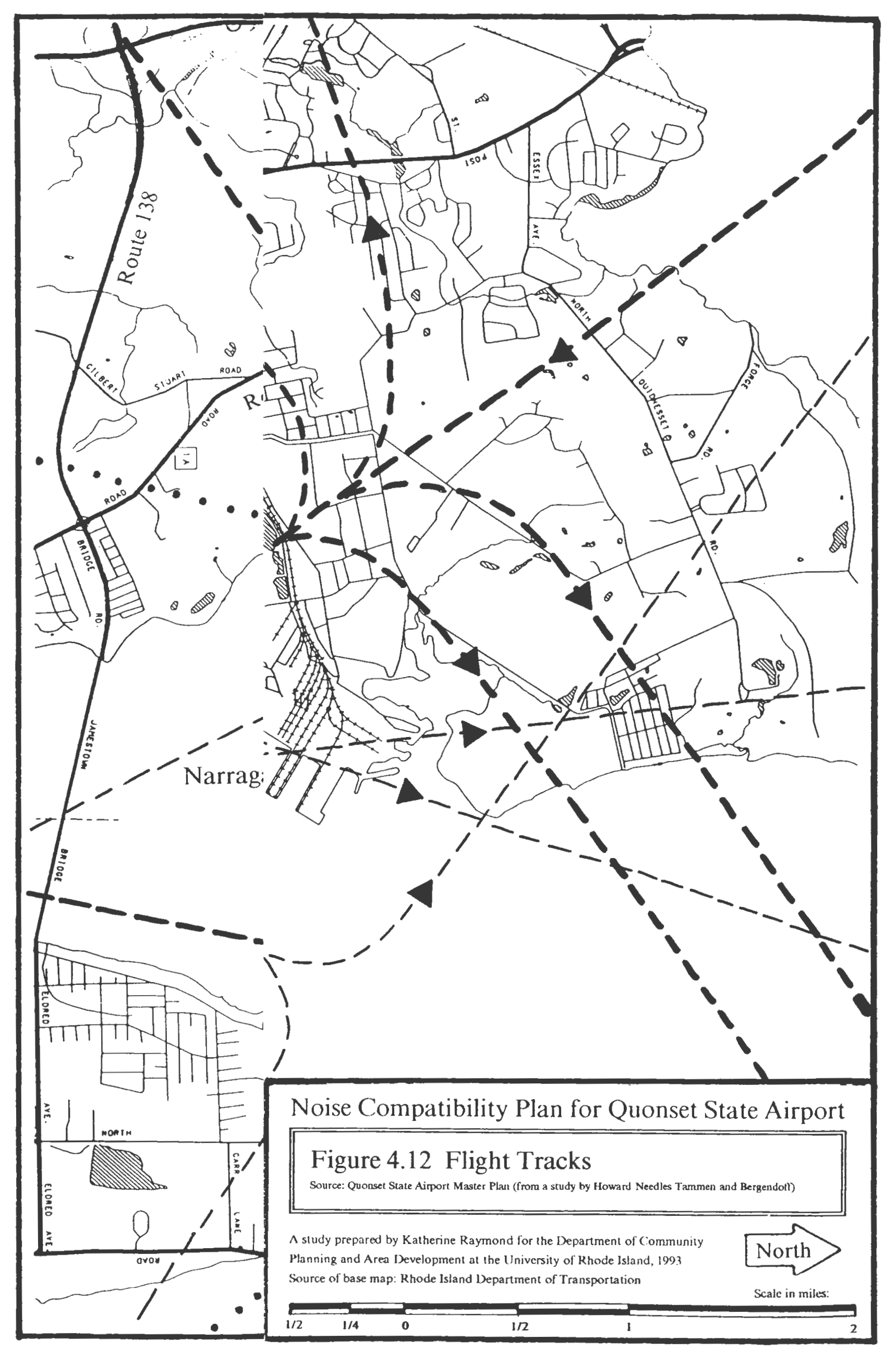


contour of a single event, operations of certain aircraft can be disruptive to a large land area that contains noise-sensitive land uses. 


\section{Notes}

1. Walter K. Schroeder, Defenses of Narragalnselt Bay in World War II, (East Greenwich: Rhode Island Publications Society, 1987): 86.

2. Ibid.

3. Ibid.

4. Rhode Island Department of Administration, Division of Planning, Quonset Statc Airport master plan, Report number 55 (1987): 2.7.

5. Data from Rhode Island Department of Administration, Division of Planning. The FAA includes touch-and-go operations in their operations data and reports 213,000 operations for T.F. Green in 1990. U.S. Department of Transportation, Federal Aviation Administration, National plan of integrated airport systems 1990-1999(Washington, D.C., 1991): 424.

6. National plan of integrated airport systems, 422.

7. Quonset State Airport master plan. 2.24.

8. Quonset State Airport master plan, 2.25.

9. ILT Brian C. Trapani, 1/126 Attack Helicopter Battalion. Based helicopters include $21 \mathrm{AH}-$ 1 (Cobras), 13 OH-6 (Scouts), and 3 UH-1 (Hughies).

10. Air National Guard Operations. Based aircraft include 8 C-130 airplanes.

11. RI Statewide Planning Program, State airport system plan, Report number 47 (1984): 3.1.

12. Ibid.

13. Operations, passenger, and cargo data include only up to 1991. Data collected in 1992 is available, but not reliable, due to the misfortune of the illness and death of the airport manager who was responsible for this task.

14. 1992 data for QSA may not be reliable. See the previous note.

15. Quonset State Airport Operations, Air National Guard Operations, and Army $\Lambda$ viation Support Facility Operations.

16. State airport system plan, 6.5 . 


\section{CHAPTER FIVE \\ FOR ECASTS}

Predicting regional transportation needs is not easy, especially during this period of economic uncertainty and reduced government spending in the United States. There are national trends of defense spending and economic growth (or decline), and patterns of migration and population growth that dictate housing trends. Growth and change in North Kingstown and Jamestown, and at Quonset State Airport may or may not follow national trends and growth patterns.

Given that the national cconomy is now recovering from a fifty year old Cold War policy based on national defense spending, and a period of real estate speculation in the 1980's, the economy of the future is likely to be more conservative. Government spending will be planned more carefully, and risks will be assessed more critically. The slow recovery from the recession will evolve into a period of slow, but steady growth while the nation and the northeast continue to adapt to a post-industrial society.

In light of these conditions, this chapter attempts to predict future conditions in the study area. Forecasts for North Kingstown and Jamestown will assume slow, but steady growth in the foreseeable future. The redevelopment of Quonset Point as a whole will also be looked at, as that may have an impact on airport use. Future use of the airport itself will be estimated. Specifically, the number of operations will be forecasted along with the resulting noise contours. 


\section{North Kingstown and Jamestown}

The future of North Kingstown and Jamestown will be examined in the areas of population and housing (discussed together), land use, economic development, and capital improvements. These five descriptors will be indicative of both the climate to support and encourage aviation, and of the possible exposure of the community to noise. All information in this section was obtained from the Comprehensive Plans of both of these towns.

\section{Population and Housing}

The North Kingstown Comprehensive Plan projects 2.7 percent growth in population from 1990 to 2000 and from 2000 to 2010 . The Jamestown Comprehensive Plan projects 7.8 percent growth from 1990 to 2000 , and 2.7 percent growth from 2000 to 2010 . With these figures and the existing population of each plat or district, the population of each sub-area was forecasted. The number of housing units in each sub-area was then forecasted by dividing population increase by the number of persons per household ( 2.70 in North Kingstown and 2.42 in Jamestown). This data is shown in Table 5.1. Both towns have completed a "build-out" analysis which demonstrates the maximum number of housing units and population that could occur if all undeveloped parcels are developed to the maximum density that is permitted by zoning. Growth estimates do not approach this maximum density. The Quonset Point/Davisville district does not have any developable residential zoned land, so no growth is predicted. 
Table 5.1 Population and Housing Units Forecast

\begin{tabular}{|c|c|c|c|c|c|c|c|c|}
\hline \multirow{2}{*}{$\begin{array}{c}\text { District } \\
\text { Plat }\end{array}$} & \multicolumn{4}{|c|}{ Population } & \multicolumn{4}{|c|}{ Housing units } \\
\hline & $\begin{array}{c}1990 \\
\text { actual }\end{array}$ & $\begin{array}{l}2000 \\
\text { est. }\end{array}$ & $\begin{array}{l}2010 \\
\text { est. }\end{array}$ & $\begin{array}{l}\text { Build- } \\
\text { out }\end{array}$ & $\begin{array}{c}1991 \\
\text { actual }\end{array}$ & $\begin{array}{l}2(n) 0 \\
\text { est. }\end{array}$ & $\begin{array}{l}2010 \\
\text { cst. }\end{array}$ & $\begin{array}{l}\text { Build- } \\
\text { sut }\end{array}$ \\
\hline \multicolumn{9}{|c|}{ North Kingstown } \\
\hline Quidnessett & 9783 & 10324 & 10624 & 12437 & 3623 & $3 \times 24$ & 3935 & 4606 \\
\hline Coastal Villages & 7874 & 8458 & 8766 & 11758 & 2827 & 3133 & 3247 & 4266 \\
\hline Quonset/Davis. & 954 & 954 & 954 & 954 & 353 & 353 & 353 & 353 \\
\hline Sub-total & 18611 & 19736 & 20344 & 25149 & 6803 & 7310 & 7535 & 9225 \\
\hline N. Kingstown & 23861 & 26821 & 28271 & 43461 & 9850 & 9934 & 10471 & 18449 \\
\hline \multicolumn{9}{|c|}{ Jamestown } \\
\hline 1 & 215 & 232 & 238 & 614 & 81 & 88 & 41 & 246 \\
\hline 2 & 300 & 323 & 332 & 498 & 112 & 122 & 125 & 194 \\
\hline 3 & 562 & 606 & 622 & 775 & 211 & 229 & 236 & 299 \\
\hline 4 & 194 & 209 & 215 & 339 & 72 & 78 & 81 & 132 \\
\hline 5 & 403 & 434 & 446 & 638 & 151 & 164 & 169 & 248 \\
\hline 15 & 374 & 403 & 414 & 582 & 140 & 152 & 157 & 226 \\
\hline 16 & 2() 4 & 220 & 226 & 412 & 76 & 83 & 85 & 162 \\
\hline Sub-total & 2252 & 2427 & 2493 & 3858 & 843 & 916 & 944 & 1507 \\
\hline Jamestown & 5800 & 6252 & 6421 & 9172 & 2061 & 2248 & 2318 & 3455 \\
\hline $\begin{array}{c}\text { Total } \\
\text { study area }\end{array}$ & 20863 & 22163 & 22837 & 29007 & 7646 & 8226 & 8479 & 10732 \\
\hline
\end{tabular}

Source: Adapted from Comprehensive Plans of both towns.

The population of the study area in North Kingstown is expected to increase from 18,611 in 1990 to 20,344 in 2010 and in Jamestown from 2252 to 2493 . The net increase in the population of the entire study area during this twenty-year period will be 9.1 percent, or 1974 
people. The additional housing units that will be needed to support this projected growth number 732 in North Kingstown and 101 units in Jamestown, for a total of 833 new units in the study area.

\section{Land Use}

The future land use of a town is dependent on a number of factors including land values, the economy, transportation improvements, and zoning. In the evolutionary process of land use, undeveloped land becomes occupied and existing developed land undergoes a change in use and value. Both North Kingstown and Jamestown have mapped future land use in their comprehensive plans. An adaptation of these two maps for the areas included in the study area appears in Figure 5.1. As with zoning and existing land use, the towns use different categories, and Table 5.2 shows the land use categories of each town and their corresponding categories used in the study area.

Land use is compared to the zoning map which appeared in Figure 4.10. In North Kingstown, zoning and future land use coincide closely. The Town maintains a commercial corridor on Route 1 , and a high density core along Route $I$ and in Wickford Village. Coastal areas in the northern section of town are zoned as low density residential but future land use is shown as open space. In the study area, industrial areas and open space are retained immediately adjacent to the airport. There are areas of low, medium, and high density residential and two schools beyond the end of Runway 34 . 


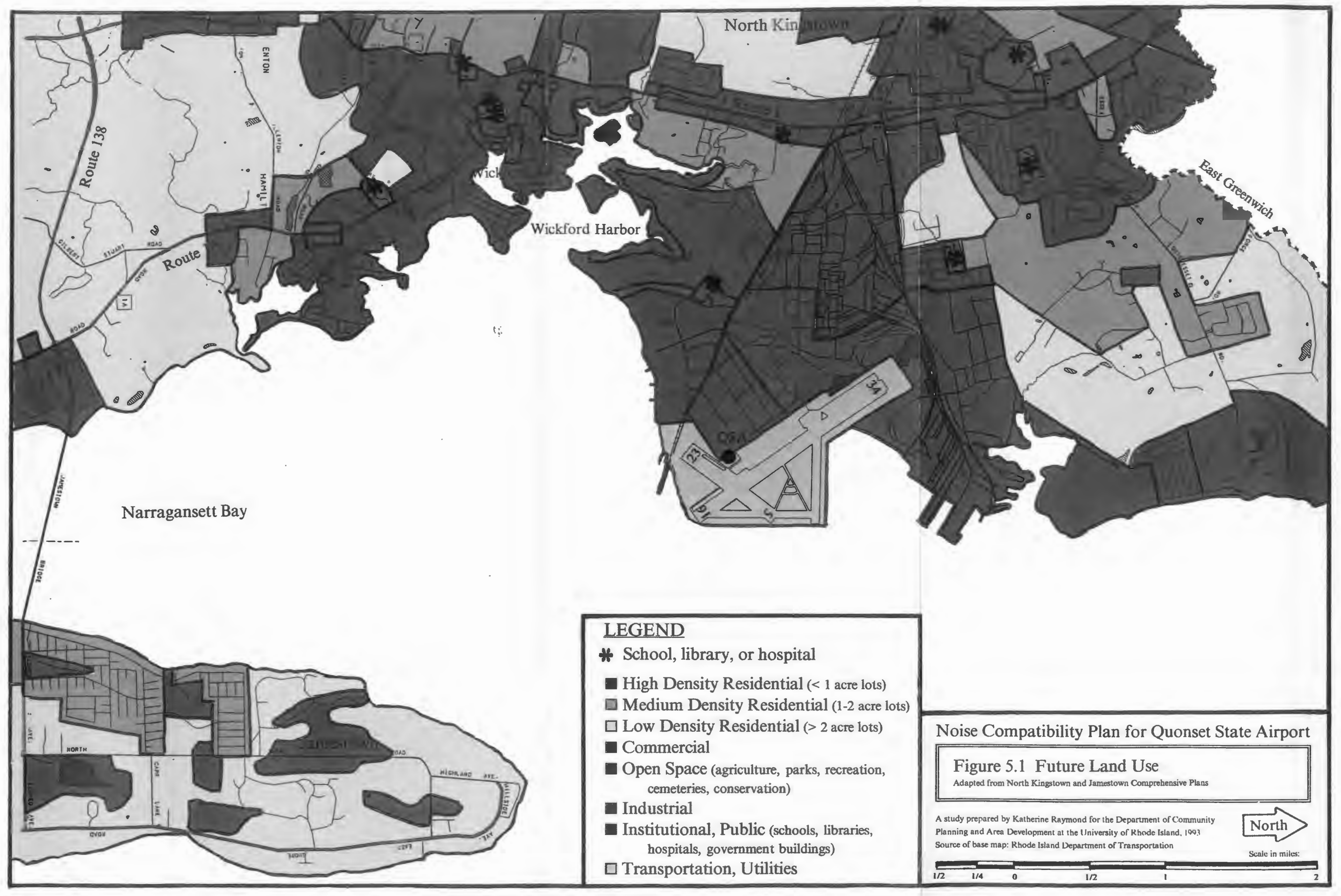


Table 5.2 Future Land Use Categories

\begin{tabular}{|c|c|c|}
\hline Study area & North Kingstown & Iamestown \\
\hline High density residential & $\begin{array}{l}\text { High density residential } \\
(20,000-40,0(0) \text { SF lots })\end{array}$ & $\mathrm{N} / \mathrm{A}$ \\
\hline Moderate density residential & $\begin{array}{l}\text { Moderate density residential } \\
(40,000-80,000 \text { SF lots })\end{array}$ & $\begin{array}{l}\text { Moderate density residential } \\
(40,000 \text { SF lots, minimum) }\end{array}$ \\
\hline Low density residential & $\begin{array}{c}\text { Low density residential } \\
(80,(000-120.000 \text { SF lots }) \\
\text { Very low density residential } \\
(>120,000 \text { SF lots })\end{array}$ & $\begin{array}{l}\text { Low density residential } \\
(80,000 \mathrm{SF} \text { lots, minimum) } \\
\text { Very low density residential } \\
(200,000 \mathrm{SF} \text { lots, minimum) }\end{array}$ \\
\hline Commercial & $\begin{array}{l}\text { Commercial; } \\
\text { neighborhood commercial: } \\
\text { waterfront commercial }\end{array}$ & $N / A$ \\
\hline Institutional/Public & Institutional/public & $N / A$ \\
\hline Industrial & $\begin{array}{l}\text { Light industrial: } \\
\text { general industrial }\end{array}$ & $\mathrm{N} / \mathrm{A}$ \\
\hline Transportation/Utility & Institutionalipublic & $N / A$ \\
\hline Open space & $\begin{array}{l}\text { Open space; } \\
\text { institutional/public }\end{array}$ & $\begin{array}{c}\text { Agricultural: } \\
\text { conservation/recreation }\end{array}$ \\
\hline
\end{tabular}

In Jamestown, the entire portion of the island included in the study area is zoned as low and moderate density residential, but future land use includes open space. The open space may be wetlands, protected farm and forest or conservation areas. The Town uses this type of low density zoning to preserve the rural character of the island. There are no schools, libraries, or hospitals in the northern part of Jamestown.

\section{Economic development}

The local economic development strategy is important in determining the future 
character of a town. North Kingstown has a diverse economic base and actively encourages commercial and industrial development in areas other than Quonset Point. (Quonset Point is an integral part of North Kingstown's economic development strategy and will be discussed separately in the following section.) North Kingstown and Jamestown are similar in their support of waterfont and tourism related businesses.

Jamestown is more of a residential community because its fragilc ecological environment can not support more intensive use. Industrial development is not permitted, and appropriate commercial development is encouraged only in designated downtown and waterfront commercial districts, none of which are included in the study area. Farming is an activity that is encouraged through the Farm and Forest Protection Program.

\section{Capital Improvements}

The Town of Jamestown has little planned in the area of capital improvements in the northern part of the island. Public water and sewer lines do not exist in this part of Town, nor are there plans to extend them. Density of development is limited by the poor soils and by the use of Individual Sewage Disposal Systems and private wells. With the exception of a possible widening of Route 138, no major roadway improvements are anticipated. The completion of the new Jamestown Bridge in the fall of 1992 has made the island more accessible, but that will have little bearing on future development because of the existing zoning requirements.

North Kingstown has no public sewers but there are some private ones. In the future, it is anticipated that areas along Route 1 will tie into the Quonset sewage treatment plant. This 
will increase the capacity for development along this commercial corridor.

\section{Quonset Point/Davisville}

At least two master plans have been prepared for the reuse and redevelopment of this site. The first one (1978) was based on possible off-shore oil drilling in Narragansett Bay, which never materialized. The most recent one (1986) was prepared during a time of economic prosperity and is overly optimistic. While some industry and state government activities have located there since the Navy pulled out in 1974, the potential of this area to support development and provide jobs has been unrealized. The stagnant economy is partially to blame for the vast underutilization of these 3100 acres of land, and there is little indication that a strong recovery and surge of industrial development lies in the near future.

The most promising prospect for future development is a partnership between the private sector, the Rhode Island Port Authority (RIPA), and Rhode Island Departments of Transportation and Economic Development (RIDOT and RIDED). Because of the deep-water port and rail lines that already exist, Quonset Point/Davisville has a bright future as a major national or international shipping facility. The Town of North Kingstown is pursuing national designation as a Federal Trade Zone (FTZ) and State designation as an Enterprize Zone, both of which could have a dramatic impact. ${ }^{1}$ North Kingstown has adopted the policy of providing the necessary infrastructure to encourage this type of development. The access road to the airport is currently being upgraded, and a new road between Route $I$ and Route 4 is being considered to further facilitate access to the highway network. 
Even if this type of cargo facility becomes a reality there will still be space for additional industrial sites. Target industries for Rhode Island include medical, scientific and electronic equipment. The State of Rhode Island Economic Development Strategy has prepared a table that lists developable areas, appropriate uses, and development and employment potential. (Shown in Table 5.3), and Figure 5.2 shows the areas of Quonset Point/Davisville that are referred to in the table.

Table 5.3 Quonset Point/Davisville Development Potential

\begin{tabular}{|c|c|c|c|c|}
\hline Developable arca & Appropriate uses & Acres & $\begin{array}{c}\text { Development } \\
\text { polential } \\
\text { (square feet) }\end{array}$ & $\begin{array}{c}\text { Employ- } \\
\text { ment } \\
\text { potential }\end{array}$ \\
\hline Central Quonset & Light industrial & 20 & 217,800 & 348 \\
\hline Kiefer Park & Industrial Park & 67 & $1,021,500$ & 1273 \\
\hline West Davisville & $\begin{array}{c}\text { Medium industrial, } \\
\text { warehouse/distribution }\end{array}$ & 65 & $1,274,100$ & 1131 \\
\hline 1)avisville Piers & $\begin{array}{c}\text { Port and marine related } \\
\text { industrial }\end{array}$ & 18 & 78,400 & 90 \\
\hline Dogpatch Beach & Marine related industrial & 30 & 130,700 & 228 \\
\hline North Davisville & Industrial park & 15 & 228,700 & 113 \\
\hline South Davisville & Medium industrial & 22 & 239,600 & 442 \\
\hline $\begin{array}{l}\text { South Davisville } \\
\text { (Mill Creek) }\end{array}$ & $\begin{array}{c}\text { Industrial corporation, } \\
\text { business park }\end{array}$ & 67 & $1,021,500$ & 1165 \\
\hline Total & & 304 & $4,212,300$ & 4790 \\
\hline
\end{tabular}

Sourc: Adapted from the North Kingstown Comprehensive Plan. p. D.3-16.

In addition to this 304 acre complex, more land may become available when facilities retained by the Navy in 1974 are closed down within the next few years. The vast development 


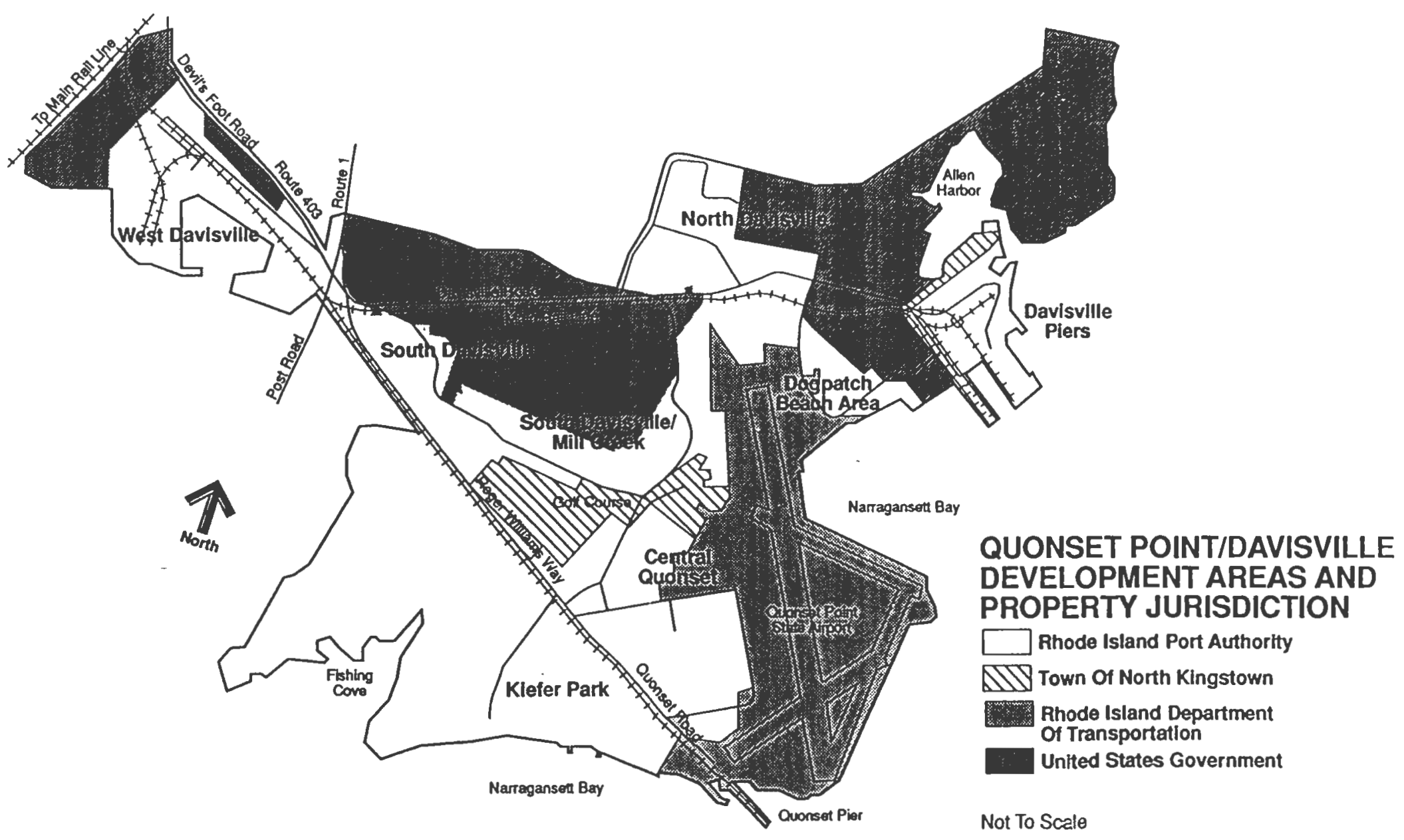

Figure 5.2 Quonset Point/Davisville Development Areas and Property Jurisdiction Source: Town of North Kingstown Comprehensive Plan, 1992, p. ED-1. 
potential of this site will not be realized in the near future, but because of the transportation and utilities that exist, it will eventually be developed when the economy can sustain new industry. It is beyond the scope of this study to determine the intensity, type, or timing of this growth, but the potential certainly exists, and whatever growth that occurs will serve to increase demand at Quonset State Airport in the form of corporate jets, air taxi service, and cargo shipping.

\section{Quonset State Airport}

In forecasting the future growth of Quonsct State Airport, it is important to look at three geographical areas: the immediate surroundings (i.e. Quonset Point/Davisville); the State airport system (T.F. Green in particular); and the Northeast Region (from New York to Boston). Quonset PoinvDavisville was addressed in the previous section, but the State airport system is discussed in this section. The Northeast region is mentioned briefly because Rhode Island is part of this larger network. Other factors that affect the use of the airport are examined, such as the National Guard units, fixed-base operators, and any capital improvements planned for QSA.

\section{Northeast Region}

Airspace is at a premium in the entire Northeast from New York to Boston. All of the major airports exceed an average of seven minutes of delay per operation, including T.F.

Green. ${ }^{2}$ Delay of a flight can be caused by two things: weather and congestion. While it is impossible to tell from these figures what percentage is attributable to weather, it is widely 
accepted that most major airports are over-crowded.

The FAA projects a 19 percent increase in annual operations from 1990 to 2000 at Logan International Airport in Boston (from 436,000 to 519,000), and a staggering 90 percent increase at Bradley International Airport in Windsor Locks, Connecticut (from 181,000 to 343,000 ). The FAA predicts only a 4 percent increase at T.F. Green (from 213,000 to 221,000). Note that the FAA and the State have different definitions of operations. In any case, a huge increase is anticipated at Bradley, and that may very well force certain operations to relocate to other general aviation airports in Connecticut, or possibly to T.F. Green or Quonset State Airports in Rhode Island.

\section{Rhode Island State Airport System Plan}

The major airport in the State that would have any significant impact on the future of Quonset is T.F. Green. When the new passenger terminal is built, ${ }^{4}$ the capacity for transporting passengers will be increased. Demand will most likely increase in a slow but steady pattern. The FAA forecast mentioned above includes 60,000 commercial operations for 1995.

The State's latest forecast for operations at T.F. Green show between 66,000 and 73,000 commercial operations in 1995 , depending on the new terminal. ${ }^{6}$ Clearly, the State is slightly more optimistic than the FAA in its predictions of future growth.

Several years down the road, if Green is receiving increased traffic due to congestion at Bradley, general aviation and cargo operations may be shifted to other airports. General aviation will be diverted to North Central or to Quonset. Cargo will be shifted from Green, 
except that the reason is more likely to be noise abatement than overcrowding. T.F. Green already has a serious noise problem, and its landlocked location in a densely developed city makes airport expansion and noise abatement extremely expensive. Shifted cargo operations would not go to North Central, they would almost definitely go to Quonset because of the longer runway, instrument landing system, control tower, and available space for hangars.

\section{National Guard Units}

There are no indications that the Air National Guard and Army National Guard will decrease their presence at QSA. They are the major contributors to airport use and will continue to occupy three of the four original hangars,' also, the Air National Guard has built an additional hangar. The Air Guard has 8 based C-130 planes that may be replaced by newer models. The number of based aircraft in the past has fluctuated from 81010 , so 10 will be used as the worst case scenario forecast. There is every confidence that the unit will remain because as other American units are deactivated in Europe, the need for airlift units in the United States will increase.

The Army Aviation Support Facility is updating its fleet of helicopters: 3 OH-6 Hughes 500 will be replaced by 3 OH-58 Bell 206; 3 UH-1 Hughies will be replaced by 3 UH-60 Blackhawks. New S-model Cobras will replace the F-model Cobras. In addition, the unit is scheduled to receive 5 C-23 cargo planes. They are similar to the Air Guard's C-1 30 turbo-prop planes, but are a little smaller. In this scenario, there should be a net increase in based aircraft. There is an outsidechance that an assault battalion of 15 Blackhawk helicopters will replace the 
attack helicopter battalion, but as with many military projects, it is subject to change." The worst case scenario as far as noise is concerned is if the attack helicopter battalion remains and adds 5 cargo planes to its fleet.

\section{Fixed-Base Operators}

It is not likely that scheduled passenger service will ever be established at Quonset State Airport. Consequently, the presence of fixed-base operators will have the most significant impact on the airport. Because there is a relatively minor noise impact at Quonset, and because the land surrounding the airport is water, open space, and ind ustrial land, QSA is perceived to be an ideal location for future growth. The Airport Corporation as a division of RIPA will encourage the development of QSA as a cargo facility. An interview with the airport manager and a current fixed-base operator ${ }^{10}$. that sells fuel revealed that several other businesses have a sustained interest in locating at Quonset. The poor economy, lack of local tax incentives, and the State's desire to lease and not sell land is impeding growth at the airport. When these financial conditions change, the following FBO's may begin operations at QSA:

1) Federal Express has kept in contact with the airport for several ycars waiting for the proper incentives to relocate. If in fact they do, they will have 3 based aircraft ( 1 DC-9 and 2 B-727's) and 6 operations per day ( 3 between 10 p.m. and 12 a.m. and 3 between 6 a.m. and 8 a.m.).

2) An air charter business consisting of one turbo-prop aircraft will have 6 to 8 operations per day.

3) Industrial development in Quonset Point/Davisville may include one or more corporate jets based at the airport with approximately 2 operations per day each. A Gulfstream II is an example of a corporate jet that is very loud and 
may fail to meet Stage II noise emission standards which are difficult to enforce.

4) Aerospace Industries is a firm currently based on Aquidneck Island. The owner of this firm that designs large commuter airplanes is currently looking for a manufacturing site. This business would require a large hangar facility and would have an unknown number of daily test flights.

5) The Quonset State Airport Master plan predicted that a new llight school would open at QSA before 1995. Although this has not happened yet. it is only 199.3, and it is not an unreasonable assumption. This type of business would typically have 2 light aircraft and gradually increase its fleet.

Although these possible future FBO's are contingent on several financial conditions being met, they are reasonable expectations of activity within the next 10 to 15 years at QSA. There could easily be more activity, but these are the ones that can be foreseen at this point in lime.

\section{Airport Data}

There are several commonly forecast indicators of airport activity: operations (broken down into several categories), passengers, cargo, and based aircraft. Based aircraft and operations were touched on in the immediately preceding section, and they will be elaborated on in this section. Passengers and cargo indicators do not directly bear on the amount of noise generated so they will not be forecast. The number of operations, and the number of jet operations in particular is the most important indicator, because that is the figure used in the Noise Exposure Forecast method of plotting noise contours. Trend analysis, straight line projections, and regression analysis are techniques used in forecasting. They are not used here because they would show continued slow decline of operations. The hypothesis on which this 
study is based is that the downward trend has bottomed out and that an upswing lies ahead.

Only based aircraft are used in the estimate because it is impossible to forecast operations of transient aircraft, and only jet aircraft estimates are necessary for the purpose of predicting noise. Turbo-prop aircraft (C-130's and C-23's) are a combination of jet and propeller aircraft. They have a jet, rather than a piston-driven engine, but propulsion is provided by propellers. Helicopters run the same way as turbo-props. Both will be included in the jet aircraft group, because they contribute significantly to noise. Low-flying C-130's and helicopters have been the subject of noise complaints at the airport. The non-jet aircraft group includes single and win-engine general aviation aircraft. They do not contribute significantly to noise, and they are not included in the NEF method. Table 5.4 shows the existing number of each type of aircraft and the number of daily and nightly operations. The number of jet aircraft and corresponding operations, daily and nightly, expected in the 10 to 15 year time period (2005) is estimated.

Table 5.4 Future Operations of Jet Aircraft

\begin{tabular}{|c|c|c|c|c|c|c|}
\hline \multirow{3}{*}{$\begin{array}{l}\text { Based } \\
\text { aircraft }\end{array}$} & \multicolumn{3}{|c|}{ Existing (1992) } & \multicolumn{3}{|c|}{ Future $(2005)$} \\
\hline & \multirow{2}{*}{$\begin{array}{c}\text { Number } \\
\text { of } \\
\text { aircraft }\end{array}$} & \multicolumn{2}{|c|}{ Daily operations } & \multirow{2}{*}{$\begin{array}{c}\text { Number } \\
\text { of } \\
\text { aircrait }\end{array}$} & \multicolumn{2}{|c|}{ Daily Operations } \\
\hline & & Day & Night & & Day & Night \\
\hline Military jet & 8 & 5 & 0) & 15 & 10 & 0 \\
\hline Military helicopter & 37 & 20 & 0 & 37 & 20 & 0 \\
\hline Civilian jet & 0 & 0 & 0 & 6 & 12 & 6 \\
\hline
\end{tabular}

Source: Data pertaining to cxisting aircraft obtained from Air and Army National Guard Operations 
This table requires explanation. Operations include takeoffs and landings, and numbers reflect all operations by that category of aircraft, not for each aircraft. Night operations occur between 11 p.m. and 7 a.m. Military aircraft are explained first, followed by civilian aircralt.

The 8 existing military jets are the Air Guard's C-130's. The 15 forecast military jets forecasted by 2005 are the 10 C-130's that the Air Guard is capable of maintaining and the 5 C-23's that the Army Guard is scheduled to receive. The 5 daily operations of the C-130's and 20 helicopter operations in 1992 are interpolated from the Quonset State Airport Master Plan. The Plan states that 15 percent of military operations are C-130's, 70 percent are helicopters, and 15 percent are other (most likely transient aircraft)." With the assumption that these percentages are still the same, the 10,608 military operations in 1992 were converted to daily data and divided among the aircraft. There is no indication that operations per day per aircraft will increase or decrease so the forecast is the same as the existing. The 10 forecast operations of military jets are derived from the 5 daily operations of the 8 existing C-130's; 7 more cargo planes (5 C-23's and 2 C-130's) should conceivably double the number of operations. All military operations occur between the hours of 7 a.m. and 11 p.m.

Currently, there are no civilian based jet aircraft. The previous section on FBO's estimates that in 10 to 15 years there will be 3 aircraft associated with a cargo company, 1 with an air taxi, and 2 corporate jets. Three cargo planes and two corporate jets are assumed to have one takeoff and one landing per day for a total of 10 operations. An air taxi can have up to 8 operations per day. The total number of operations for civilian jet aircraft would be 18 . Cargo 
flights are typically very late at night and very early in the morning, so those 6 operations are placed in the night category.

This is only an estimate of based jet aircraft and operations. It is conservative in some ways, (no increase in military operations) but demonstrates a worst-case scenario in other ways (all cargo operations occur at night). In any event, the worst-case scenario is not unrealistic. There are also based light aircraft and operations and transient operations of all types that are not accounted for in this table. Based light aircraft and operations will increase in a slow but steady fashion, but will not be the primary noise-makers. Transient aircraft of all types, including jets, will have an impact on noise, but are impossible to forecast. The method used for plotting the noise contours has a wide margin of error that can absorb the operations that are not accounted for.

\section{Noise Contours}

The Noise Exposure Forecast method of plotting noise contours that was discussed in Chapter Three is now applied to Quonset State Airport. It requires only the number of day and night jet operations per day for computation. From the immediately preceding section, it is predicted that there will be 6 night operations and 42 day operations per day. The night operations are multiplied by 17 to account for the increased annoyance from aircraft noise at night. This is then added to daytime operations.

$$
(6 \text { night operations } \times 17)+42 \text { day operations }=144
$$

Table 3.3 from Chapter Three is reproduced here as Table 5.5. Predicted operations in 
2005 place the observation in the $51-500$ category. There is obviously room for error. The 1992 level of operations falls in the lowest category because there are no night operations. Because the observation lies in the lower end of future category, 51-500, it is likely that noise levels will never reach the next higher level of noise, even if activity increased significantly from projected levels.

Table 5.5 Distances for Approximate NEF Contours

\begin{tabular}{|c|c|c|c|c|}
\hline \multirow{2}{*}{\begin{tabular}{c} 
Effective number of $\begin{array}{c}\text { operations } \\
\text { (night } x 17+\text { day) }\end{array}$ \\
\cline { 2 - 5 }
\end{tabular}} & \multicolumn{2}{|c|}{ Distance to NEF 30 contour } & \multicolumn{2}{c|}{ Distance to NEF 40 contour } \\
\hline \hline $0-50$ & 1000 leet & 1 mile & 0 & cnd of runway \\
\hline $51-500$ & 0.5 mile & 3 miles & 1000 feet & 1 mile \\
\hline $501-1300$ & 1.5 miles & 6 miles & 2000 feet & 2.5 miles \\
\hline more than 1300 & 2 miles & 10 miles & 3000 feet & 4 miles \\
\hline
\end{tabular}

Source: CLM/Systems, Inc., Airports and their entironments, 1972, p. 108.

An issue was raised in Chapter Three that the NEF model does not include plotting information for the NEF 20 contour. The NEF 20 contour is equivalent to the $55 \mathrm{~L}_{\mathrm{dn}}$ contour which is normally not mapped, but it is the point in the Land Use Guidance Chart where "land use controls should be considered." On a noise contour map, individual contours are parallel and increasingly further apart at the sides of the runways, and stretch out further at the runway ends. Refer back to Figure 3.2 for an example of noise contours that demonstrate this principle. A conservative method to map the NEF 20 contour is to plot it parallel and equidistant from 
the runway sides, and parallel to runway end lines to avoid exaggerating the affected area.

The future noise contour for Quonset State Airport is shown in Figure 5.3. The NEF 40 contour line is 1000 feet from the side of the runway and 1 mile from the end. The NEF 30 contour line is 0.5 mile from the side of the runway and 3 miles from the end. The NEF 20 contour line drawn conservatively is 0.8 mile from the side of the runway and 5 miles from the end. The NEF 20 line is drawn the same distance away from the NEF 30 line as the NEF 30 line is from the NEF 40 line. Contour lines do not exist for Runway 05-23 because only light aircraft takeoff and land on that runway.

The NEF 40 contour (equivalent to $75 \mathrm{~L}_{\mathrm{dn}}$ ) extends southward over the water and northward over industrial areas. The NEF 30 contour (equivalent to $65 \mathrm{~L}_{\mathrm{dn}}$ ) extends so uthward and just penetrates a small section in northwestern Jamestown. To the north, it just touches East Greenwich. The NEF 20 contour (equivalent to $55 \mathrm{~L}_{\mathrm{dn}}$ ) extends southward, crosses the island of Jamestown, and protrudes very slightly over the water beyond the study area map. In the north, this contour covers half of the Quidnessett planning district and also protrudes slightly beyond the study area map into East Greenwich. 


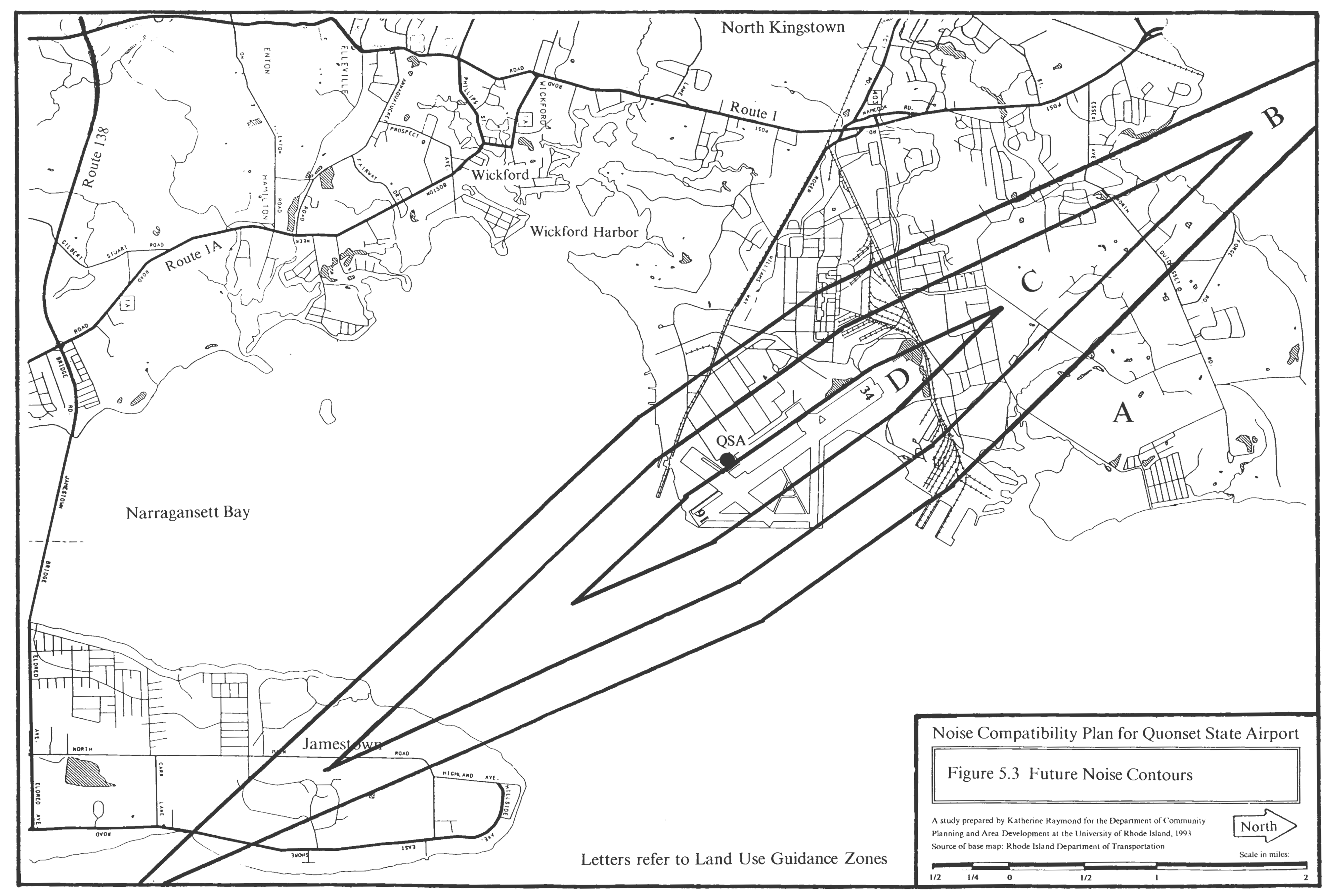




\section{Notes}

1. North Kingstown comprehensive plan, D.3-26.

2. National plan of integrated airport systems, 16.

3. Ibid. $116,246,424$.

4. At the time of this writing, there is every indication from the newspapers that it will be built.

5. Ibid. 424.

6. Greiner Engineering Sciences, Inc., Final environmental impact statement for the terminal area plan at the T.F. Green State Airport, prepared for the state of Rhode Island Department of Transportation, (1990): I-18.

7. There are also two hangars for seaplanes that are used by Electric Boat. Quonset State Airport master plan, 2.25.

8. Air National Guard Operations.

9. 1LT Brian C. Trapani, 1/126 Altack Helicopter Battalion.

10. Stephen Burns, Fantasy Air Inc.

11. Quonset State Airport master plan, 6.9. 


\section{CHAPTER SIX \\ ANALYSIS}

The analysis of data includes critical observations about the noise contour derived by the NEF method and established patterns of airspace use. With these adjustments, the future noise contour is superimposed onto existing land use, future land use, and zoning maps. Needs and constraints of the towns, such as legal, political, and financial considerations are explored; and criteria for the evaluation of noise abatement measures are established.

\section{$\underline{\text { Noise Contours }}$}

The noise contours gencrated by the NEF method as shown in Figure 5.3 are linear, show equal utilization of Runway 16 and Runway 34 for takeoffs and landings, and do not take local conditions into account. Also, the weighting factor for night time operations is somewhat severe. These issues are discussed and the contours are adjusted accordingly.

\section{Nighttime Operation Weighting Factor}

In the NEF method for estimating noisecontours, daytime operations are counted once, but each night time operation is counted 17 times. the literat ure does not explain how that figure was arrived at. Because this method was designed in the early 1970's, the impacts of Stage I aircraft were still apparent. Now, most aircraft have achieved Stage III standards. this will result in a shortening of the noise contours. 


\section{Preferential Runway}

According to the NEF method, noise contours are drawn symmetrically, meaning that each runway is utilized equally for takeoffs and landings. In reality, Runway 16 is preferred for takeoffs, and Runway 34 is preferred for landings when wind and weather conditions permit. This would cause the noise contour to cover a greater area over the southeast portion of the study area than over the northeast part.

\section{Flight Tracks}

Not only are the noise contours drawn symmetrically according to the NEF method, they are also drawn in a straight line. Actual flight tracks reveal anomalies on both ends of Runway 16-34. Refer to Figure 4.12 to see the fight tracks.

When taking off on Runway 16 , aircraft bear slightly right to head in a more southerly direction to avoid flying directly over Jamestown. Similarly, when landing on Runway 34, they try to approach over the water from the south and then make the slight left turn for the final approach. Aircraft that are landing have less freedom to maneuver around noise-sensitive areas because of the difficulty of the procedure. Consequently, landing aircraft are still apt to fly over the island, especially transient aircraft that are not familiar with local noise abatement programs. This quirk in the flight pattern will cause the noise contour to bend into a slightly trapezoidal shape.

Beyond the end of Runway 34 is T.F. Green State Airport, approximately 8.5 miles away. There is a 5-mile ring around that airport called the Airport Radar Service Area 
(ARSA). Before an aircraft can enter the ARSA, contact must be made with the control tower at T.F. Green. This ring lies just outside of the study area to the north. When pilots takeoff on Runway 34, they tend to bear left or right to avoid entering the ARSA. Aircraft landing on Runway 16 will also try to maneuver around the ARSA, but may have more difficulty. This fanning out of night tracks as they are shown in Figure 4.12 deforms the noise contour from a taper to a wider and shorter trapezoidal shape.

\section{Adjusted Noise Contour}

The overall shape of the noise contour is shorter on the northern end because of the preferred use of other end. The northern end is shortened even more and flared out to reflect the fact that aircraft ny around the ARSA rather than fly straight into it. The NEF 20 contour falls just south of North Quidnessett Road, just east of Route 1, and just southwest of the Mount View neighborhood.

The southern end of the contour is maintained at the same length to account for the preferred use of this end of the runway. It is a two point tapered shape to reflect the two actual approach flight tracks. One point is over the water, but the other point extends all the way across the island in a wedge shape. Adjusted contours are shown in Figure 6.1.

\section{Impact of Airport Noise on the Surrounding Community}

The noise that may be generated from Quonset State Airport is not an issue of widespread concern today, at least not to the same degree as T.F. Green's noise problem. 


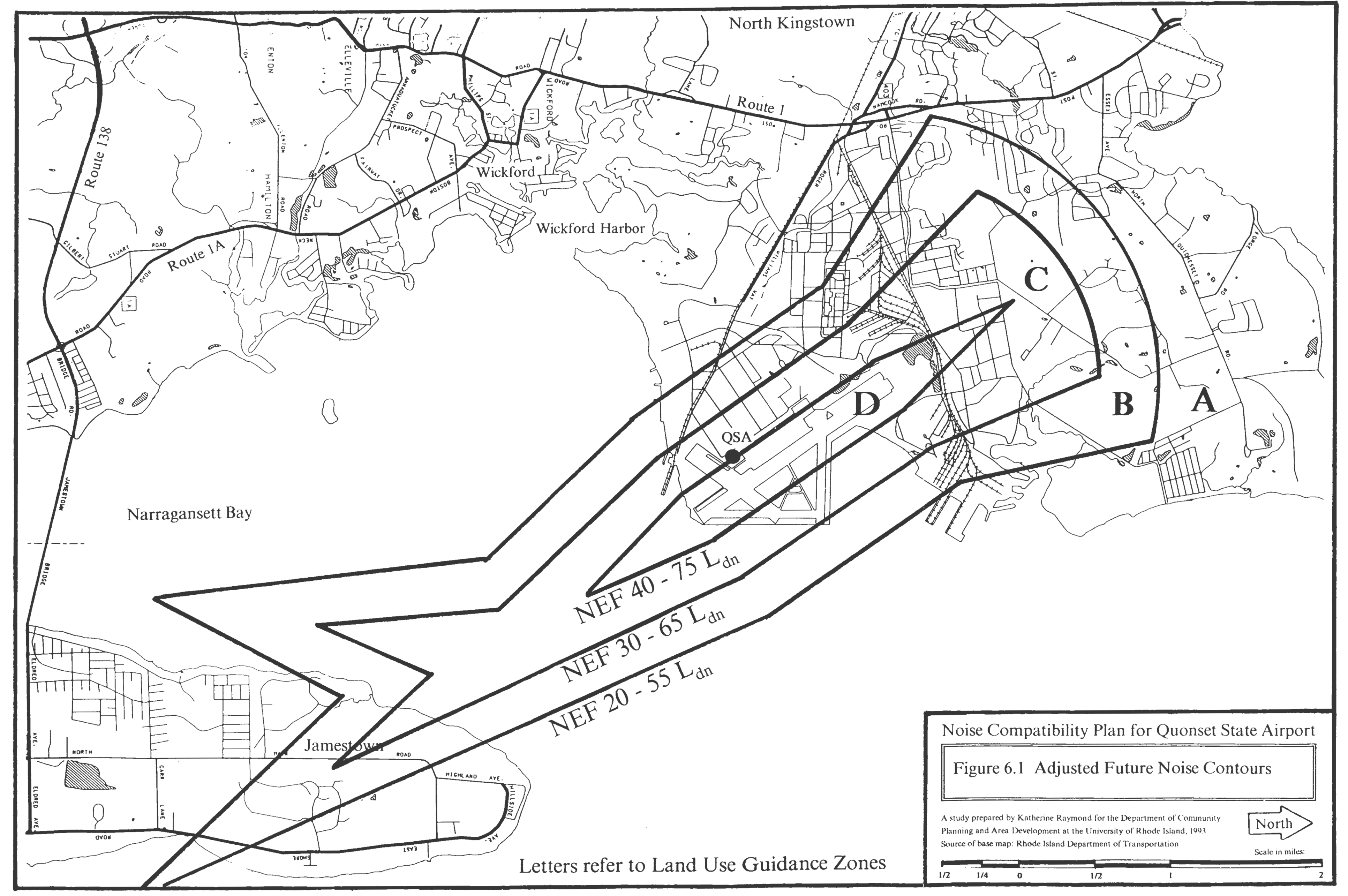


Compared to when QSA was an active naval facility, it is now relatively quiet. Other local issues, such as the redevelopment of Quonset Point/Davisville, command more attention. The Comprehensive Plans of North Kingstown and Jamestown were completed without addressing the issue of future noise. Land immediately adjacent to the airport is not intended to support noise-sensitive uses; however, there are residential areas very close by that are impacted by noise now that will worsen in the future. It is difficult to implement land use planning tools on land that is already developed, but vacant or undeveloped land can and should be analyzed with regard to the future environment. The maps appearing in Chapters Four and Five, Existing Land Use, Existing Zoning, and Future Land Use, are now used in conjunction with the adjusted future noise contours to gain insight on the types of land that will be impacted by increased airport noise.

\section{Future Noise Contours and Existing Land Use}

The noise contours show very clearly in Figure 6.2 the areas of land that are expected to be impacted by noise in the future. Table 6.1 is the Land Use Guidance Chart that was first shown in Chapter Two, Table 2.2. There is a qualitative rating given to each zone of land. The land uses that are considered appropriate for each zone are listed in Appendix A. Each zone in the study area is discussed with respect to the land uses in each one.

Land Use Guidance (LUG) Zone D is considered to have severe exposure to noise. Within the center of this contour lies Runway 16-34 and the apron and hangar space. Water, open space, and industrial land are at the ends. There is some undeveloped land at the northern 


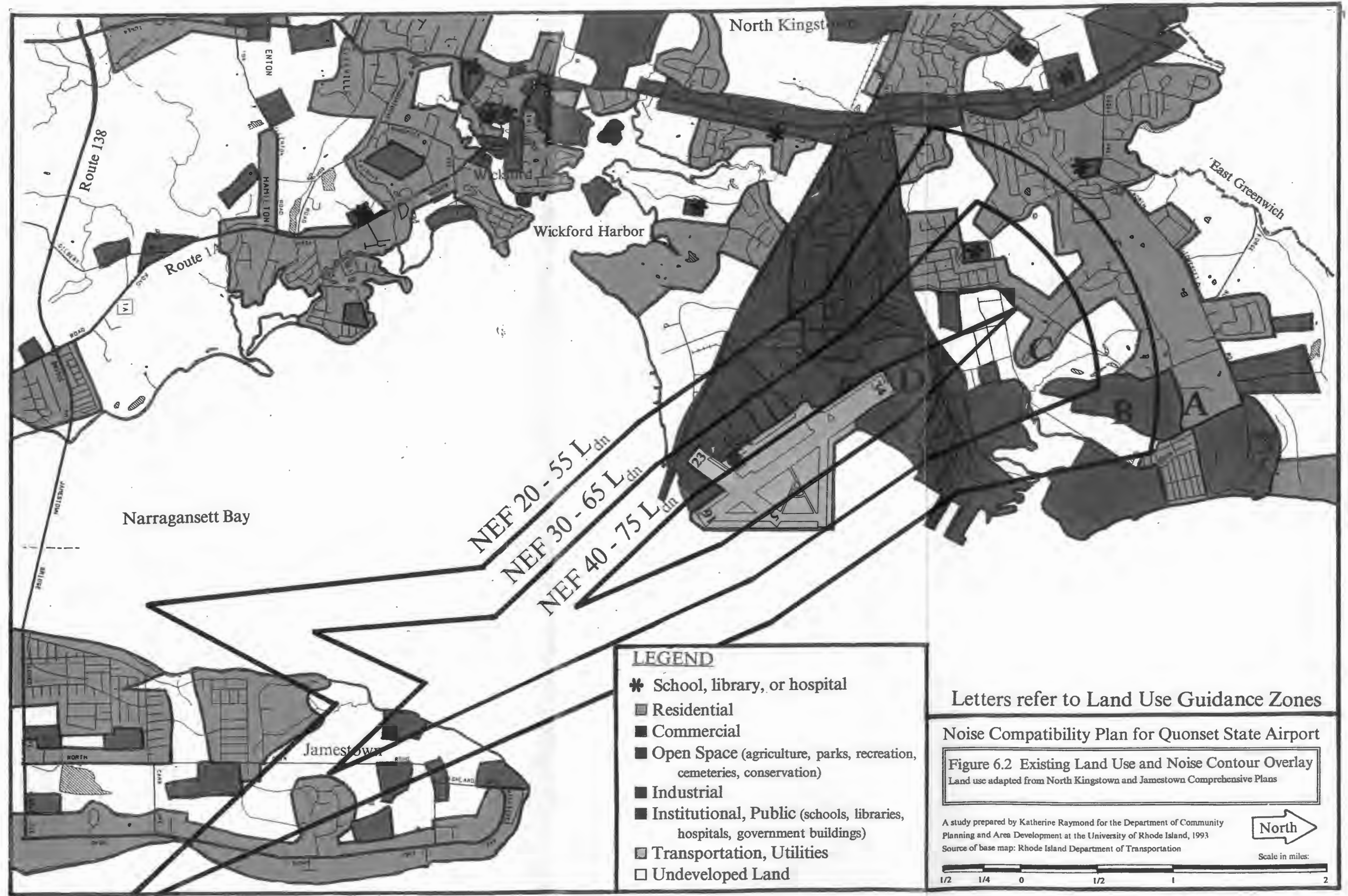


Table 6.1 Land Use Guidance Chart

\begin{tabular}{|c|c|c|c|c|c|c|c|}
\hline \multirow{2}{*}{$\begin{array}{l}\text { Land use } \\
\text { guidance } \\
\text { annes }\end{array}$} & \multirow{2}{*}{$\begin{array}{l}\text { Noise } \\
\text { expossure } \\
\text { dass }\end{array}$} & \multicolumn{4}{|c|}{ Aircraft noise estimating methodologies } & \multirow{2}{*}{$\begin{array}{l}\text { HI I) noise } \\
\text { assessment } \\
\text { guidelines } \\
\end{array}$} & \multirow{2}{*}{$\begin{array}{l}\text { Suggested noise } \\
\text { controls }\end{array}$} \\
\hline & & $\mathrm{L}_{\mathrm{Jn}}$ & $\mathrm{NEF}$ & CNR & CNEL & & \\
\hline A & minimal & $\begin{array}{l}0 \\
\text { to } \\
55\end{array}$ & $\begin{array}{l}0 \\
\text { to } \\
20\end{array}$ & $\begin{array}{l}0 \\
\text { to } \\
90\end{array}$ & $\begin{array}{l}0 \\
10 \\
55\end{array}$ & $\begin{array}{l}\text { clearly } \\
\text { acceptable }\end{array}$ & $\begin{array}{l}\text { normally reyuires no } \\
\text { special considerations }\end{array}$ \\
\hline $\mathbf{B}$ & moderate & $\begin{array}{l}55 \\
10 \\
65\end{array}$ & $\begin{array}{l}20 \\
10 \\
30\end{array}$ & $\begin{array}{l}90 \\
10 \\
100\end{array}$ & $\begin{array}{l}55 \\
10 \\
65\end{array}$ & $\begin{array}{c}\text { normally } \\
\text { acceptable }\end{array}$ & $\begin{array}{l}\text { land use controls } \\
\text { should be considered }\end{array}$ \\
\hline$C^{\circ}$ & significant & $\begin{array}{l}65 \\
10 \\
75\end{array}$ & $\begin{array}{l}30 \\
10 \\
40\end{array}$ & $\begin{array}{l}100 \\
10 \\
115\end{array}$ & $\begin{array}{l}65 \\
6 \\
75\end{array}$ & $\begin{array}{c}\text { normally } \\
\text { thacceptable }\end{array}$ & $\begin{array}{l}\text { land use, casements, } \\
\text { and other controls } \\
\text { rceommended }\end{array}$ \\
\hline$D$ & severe & $\begin{array}{l}75 \\
\text { and } \\
\text { over }\end{array}$ & $\begin{array}{l}\text { 40 } \\
\text { and } \\
\text { aver }\end{array}$ & $\begin{array}{l}115 \\
\text { and } \\
\text { aver }\end{array}$ & $\begin{array}{l}75 \\
\text { and } \\
\text { over }\end{array}$ & $\begin{array}{c}\text { dearly } \\
\text { unaceeptable }\end{array}$ & $\begin{array}{l}\text { contain within airport } \\
\text { boundary or positive } \\
\text { controls recommended }\end{array}$ \\
\hline
\end{tabular}

Source: Federal Aviation Administration. Advisory (ircular 15) 5050-6, 1977

tip of the contour that is suitable for limited future use.

LUG Zone C has significant exposure to noise. The remainder of the airport, ind ustrial land, and open space are the acceptable uses within this zone. However, there are residential areas along Potter Road and Newcombe Road, and a school in North Kingstown that may become problematic in the future. There is some undeveloped land in this zonc in North Kingstown, and a tiny portion in Jamestown that should be addressed through land use planning modifications.

LUG Zone B has moderate exposure to noise. In Jamestown, open space, residential areas, and undeveloped land fall within Zone B, as well as a lot of water in Narragansett Bay. In North Kingstown, industrial land, open space, residential and undeveloped land fall within 
this zone. LUG Zone A is minimally impacted by noise and is not addressed by most noise compatibility plans; however, there are certain precautions that can and should be taken with regard to land that lies immediately outside fabricated noise contour lines.

\section{Future Noise Contours and Future Land Use}

The vacant parcels of land mentioned in the preceding section may be undeveloped, but are envisioned by the tows to serve some particular purpose or to support a certain use. These various uses should be considered in the assessment of future noise impact. To accomplish this connection between land use and noise, the noise contours are overlaid onto the Future Land Use Map in Figure 6.3. This composite shows that currently undeveloped parcels in LUG Zone $\mathrm{D}$, the most restrictive zone for future development, are intended to be used as industrial land, which is the most appropriate use.

Land in LUG Zone C is significantly exposed to noise. Future land use indicates low density residential and open space in Jamestown for that small wedge of land. In North Kingstown, ind ustrial land, open space, and airport land uses will be compatible; however, there are also significant parcels of land intended for low, moderate, and high density residential that will not be compatible. Clearly, this must be rectified.

LUG Zone B has the same uses intended for it as Zone $\mathrm{C}$. There is more land, but there will be less of a noise impact and fewer restrictions on development. Most notable are the moderate and high density residential areas in North Kingstown. There is also a school on the outer edge of Zone B. The North Kingstown Comprehensive Plan describes the Quidnessett 


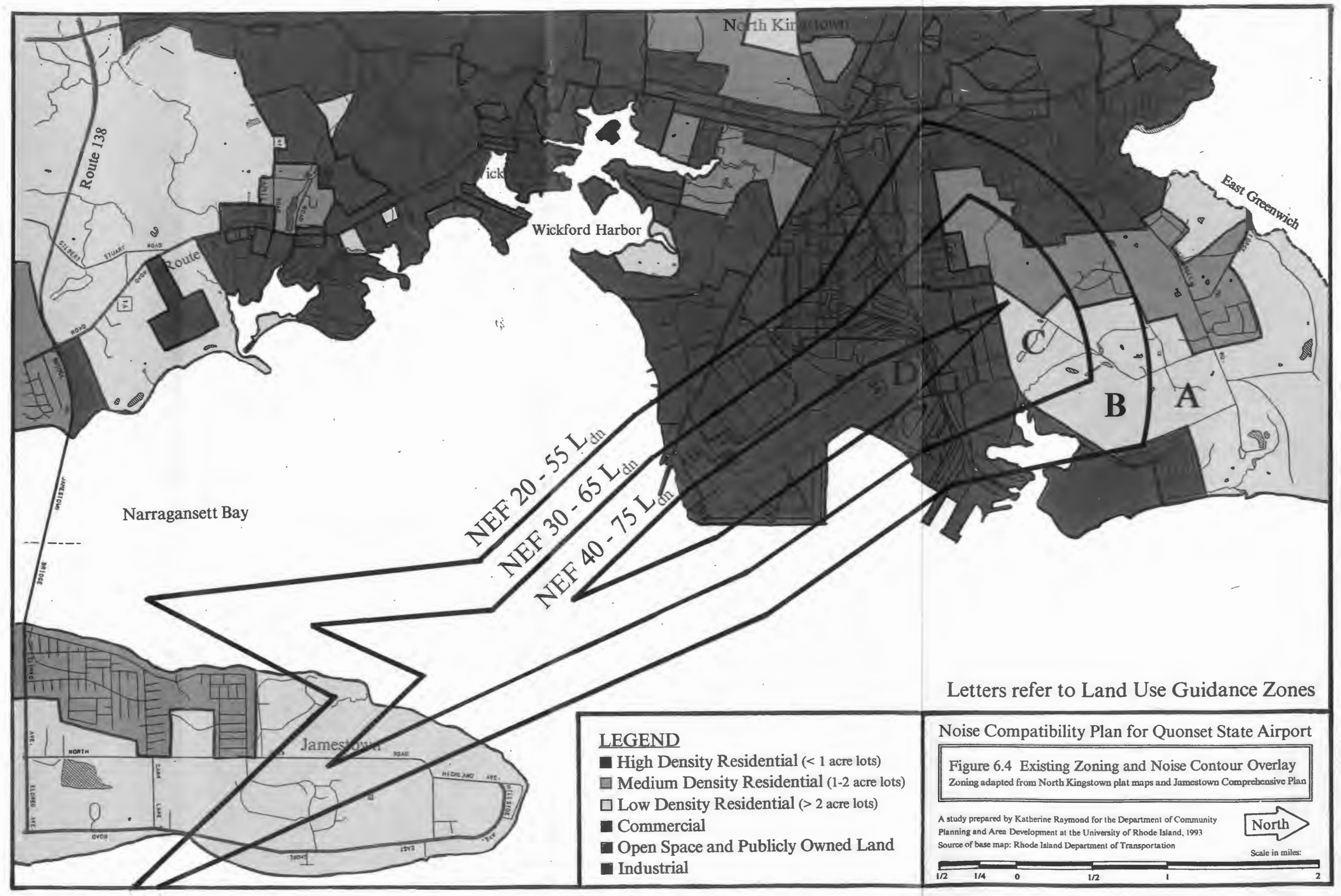


facilitate the implementation of a plan. Available resources are often the major obstacle to the satisfactory resolution of conflict. It seems that there is never enough money to complete every worthwhile project. Lack of power or jurisdiction and lack of political clout can also inhibit progress or desired results. Economic development is often at odds with or detrimental to other community goals, such as a quiet, rural setting. Equity is another issue; the whole community benefits from the presence of the airport, but a few have to suffer the consequences.

\section{Financial Resources}

Noise mitigation is a costly undertaking, and airports expend millions of dollars on land acquisition and soundproofing of existing buildings. It is impossible to tell from the data available on land acquisition, how much is raw land purchased as a preventive measure and how much is occupied land paid along with relocation costs. It is much cheaper to buy vacant land or to otherwise ensure that development is compatible with airport uses than it is to buy developed land or soundproof existing buildings.

A simple solution to prevent incompatible development in the future is to place a moratorium on all housing and noise sensitive uses in moderately impacted locations. The town, however, needs that impacted land on the property tax rolls to sustain its own services and programs. If certain low-cost and no-cost preventive measures in the form of land use controls are taken now, the Town and State can save money later, and market the airport and industrial sites as "low noise impact" to help attract shipping companies and jobs.

In the case of Quonset State Airport, the Town of North Kingstown is not liable for 
financing noise mitigation; the Airport Corporation as proprietor and as a creature of the State, is responsible. The State has greater financial resources than the Town, but has six airports to sustain. There is little money left after maintenance and operations expenses to conduct planning studies for noise abatement at airports whose noise contours do not go beyond airport boundaries.

\section{Jurisdiction}

Jurisdiction over land use control is complicated by the myriad of land owners in the Quonset Point/Davisville complex. The federal, state, and local government are all landowners, and the federal and state owned land is not subject to local zoning codes and ordinances. Beyond the immediate vicinity, there is privately owned land that is subject to either North Kingstown or Jamestown regulations. The towns have little incentive to implement land use planning for noise abatement because if and when a noise problems becomes a reality, the Town is not responsible for paying retribution. The State does not have the authority to regulate land development in municipalities, nor the money to spend on planning studies. The most reasonable alternative is to apply for federal money for noise compatibility planning. An effective plan requires coordination among all landowners and public participation.

\section{Politics}

Political clout is a factor in state government that needs to be recognized if state money supports the airport. The reason for the transfer of airport administration from the Department 
of Transportation, Division of Airports to the Airport Corporation within the Rhode Island Port Authority and Department of Economic Development is not clear. That shift may produce one of three alternative outcomes: 1) More money will be spent at Quonset to upgrade facilities and hangars and establish a cargo hub, 2) Less money will be spent at Quonset, and instead it will be funneled to T.F. Green to ensure success of the new passenger terminal, or 3) spending proportions will remain the same. It is not the purpose of this study to speculate on political motivation, only to note that it is a critical concern in the future of the airport.

\section{Community Goals}

Community goals often reflect the desire to maintain or improve a certain quality of life (e.g. agricultural community) or to maintain unique characteristics or resources within the towns (e.g. historic features). The community that desires a large airport with heavy traffic and loud planes is the exception to the rule. Airports provide jobs and attract other businesses like hotels and car rental companies that also provide jobs. In most cases it is an economic asset to the community. The minority of people who travel very frequently are airport users who reap some benefit from residing somewhat near to an airport. These advantages, however, are in conflict with normal, quiet residential neighborhoods and other noise sensitive uses, like schools, libraries, and hospitals. Nobody likes to live so close to an airport that the house rattles and the 6:30 a.m. flight is a daily alarm clock. Quonset State Airport has a disadvantage in that it is not a passenger airport, and the vast majority of local residents have no reason to go to the airport. The airport is a necessary evil that brings out the NIMBY in people (not in 
my backyard). It is difficult, but not impossible, for an airport to be both an economic asset and a good neighbor. Airport owners and planners must work with members of the community to achieve a balance of existence.

\section{Equity}

Assuming that QSA becomes a unique and irreplaceable economic asset to Rhode Island, it stands to reason that all people in the State will benefit from its presence. Some people, however, live in noise impacted areas and also suffer the side effects of the airport. It is not fair, much like the residents who live near T.F. Green or the Johnston landfill suffer consequences from activities that benefit the remainder of the entire state. Should these people be compensated for their reduced quality of life? And if so, who should pay for it? How much restitution should be paid for their annoyance? These are difficult questions that have no ready answers.

The purpose of this study is to avoid situations like this by anticipating a problem and making the necessary adjustments to land use ahead of time. Even if this is accomplished, there are pre-existing residential areas that will be subject to moderate to significant noise exposure. In this case, the State, as proprietor of the airport, is solely responsible for compensatory remedies. How much will be determined by the severity of the noise and the market for noise easements. 


\section{Legal Implications}

Case history has shown, as discussed in Chapter Two, that the airport proprietor is financially responsible for mitigation of noise because they supposedly chose the site for the airport. Courts have found that airlines and the federal government are not accountable. In the case of Quonset State Airport, the federal government chose that site for a Naval Base. The State assumed control of an existing facility several decades later. The question of legal liability probably would not be answered until a case is decided court.

\section{Evaluation Criteria for Noise Abatement Methods}

The methods available for noise abatement that were presented in Chapter Three will be applied to the study area. Actual recommendations will follow in Chapter Seven in two phases: short term (should be considered within the next two years); and long term (should be used when actual noise levels are high enough to justify the cost). There are different criteria that will be used to assess the value of each method: cost, effectiveness (will noise be reduced significantly), ease of implementation (or administration or construction), and timeliness (will the method provide immediate or future relief).

Cost. Some techniques, such as plat map notices cost very little to implement. This simply involves placing a written notice on official town maps where they are available to the public. Other methods, such as building soundproofing and land acquisition, can be extremely expensive. Costly measures should be reserved for the long term when the expense can be justified by noise levels. 
Effectiveness. Some methods are more effective than others. Soundproofing a building can effectively reduce interior noise by 20 decibels. Techniques such as building a noise berm are effective only if the generator of noise or the receiver of noise is very close to the berm. Because no residential properties are immediately adjacent to Quonset State Airport, that is not the most effective technique in this case.

Ease of implementation. Certainly administrative and legal remedies, such as zoning changes or plat notices, are easily administered. Other methods, such as building soundproofing and purchasing easements from many landowners, are laborious and time consuming, or may instigate conflicts and lawsuits.

Timeliness. Some methods of land use planning are intended to provide long term benefits, while others, such as airport operating procedures, have immediate benefits. The first phase of recommendations (considered in the short term) concentrates on long term benefits. When noise levels become more severe in the future, that is the appropriate time to implement immediate impact noise abatement measures. 


\section{CHAPTER SEVEN RECOMMENDATIONS}

The findings of this study have led up to a list of recommendations that are necessary to ensure that future development of the Towns of North Kingstown and Jamestown is compatible with the projected intensified use of Quonset State Airport. Land use planning is the vehicle used to achieve harmonious growth. Recommendations are presented in two phases: Phase I recommendations consist of preventive land use planning strategies implemented primarily by the towns, and Phase II consists of corrective and compensatory mitigation strategies that apply to pre-existing uses and structures implemented by the State of Rhode Island.

\section{Phase I Recommendations - Land Use Controls}

The key to an effective land use plan is an accurate assessment of future conditions and early implementation of land use controls in anticipation thereof. Phase I recommendations are preventive and are designed to be helpful if they become effective within the next year or two. They do not involve the expenditures associated with corrective or compensatory noise mitigation strategies. The whole point of this study is that the Towns of North Kingstown and Jamestown have this opportunity to anticipate increased airport use and plan accordingly. Recommendations are discussed in order of general strategies affecting large land areas to specific ones affecting smaller areas. 


\section{Full Disclosure}

Rhode Island State real estate law currently requires real estate agents to disclose to potential buyers any defects or flaws associated with property or impacting property values. However, it is reasonable to assume that agents today do not consider Quonset State Airport to be a threat to a quiet suburban or small town lifestyle. The Towns of North Kingstown and Jamestown should adopt an ordinance affecting all homes for sale in both towns to require real estate agents to disclose the existence of the airport and the possibility of future growth and noise disturbances. Oftentimes buyers will visit on weekends when there are fewer airport operations and may not be aware of actual noise levels.

\section{Plat Map Notices}

Certain areas of North Kingstown and Jamestown should have notices placed on the Town's plat map that an airport exists in the area, and that homes located within the plat are subject to periodic noise disturbances even though they may be outside of the noise contour lines. In Jamestown, the entire northern half of the island, should be included because aircraft flight tracks cross the area and it is in close proximity to the NEF 20 contour. The corresponding plat numbers are 1-5, 15, and 16 and are shown in Figure 7.1.

In North Kingstown, most of the northeastern section of the Town should be included. Plats that are in close proximity to the NEF 20 contour line or that show flight tracks of heavy planes or helicopters are expected to be impacted by noise. This area is bordered by Wickford Harbor, Mill Creek, and Camp Road to the south, railroad tracks to the west, and the East 


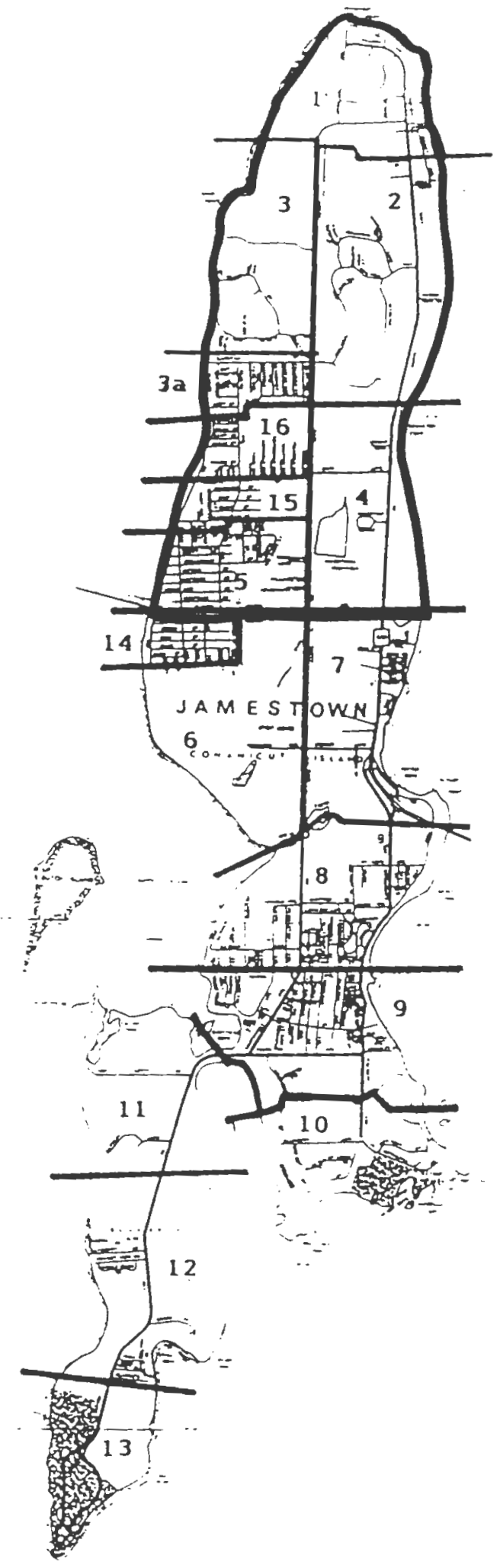

Figure 7.1 Jamestown - Recommended Plat Map Notices Source of base map: Jamestown Comprehensive Plan 
Greenwich border to the north. The corresponding plat numbers as shown in Figure 7.2. are $32,50,55,89,107,138,140-149,155-176$, and 178-195, with the airport located on plats $187-$ 189.

The Wickford Village area is not included because flight tracks in Figure 4.12 indicate that only one route for small aircraft is utilized there. The Coastal Villages district south of the harbor is not included either because of the increased distance from the airport and because the noise contours are not proximal.

\section{Airport Overlay District}

State Airport Zoning Laws (Title I, Chapter 3 of Rhode Island General Laws) address airport hazards which are defined as:

"...any overhead power line which interferes with radio communication between airport and aircraft approaching or leaving same, or any structure or tree or use of land which obstructs the airspace required for the light of aircraft..." (R.I.G.L. 1-3-2).

Clearly this refers to structures and trees in approach zones as hazards to the aircraft and not to aircraft noise as a hazard to the community. Specifically, the State grants authority to towns to divide airport hazard areas into smaller zones and to specify uses that are permitted and maximum height of objects (R.I.G.L. 1-3-5). An amendment to this section is necessary to add airport noise exposure zones to airport hazard areas as land over which the town has authority to control.

The State of Rhode Island Zoning Enabling Act (R.I.G.L. 45-24-27) is a guide to 


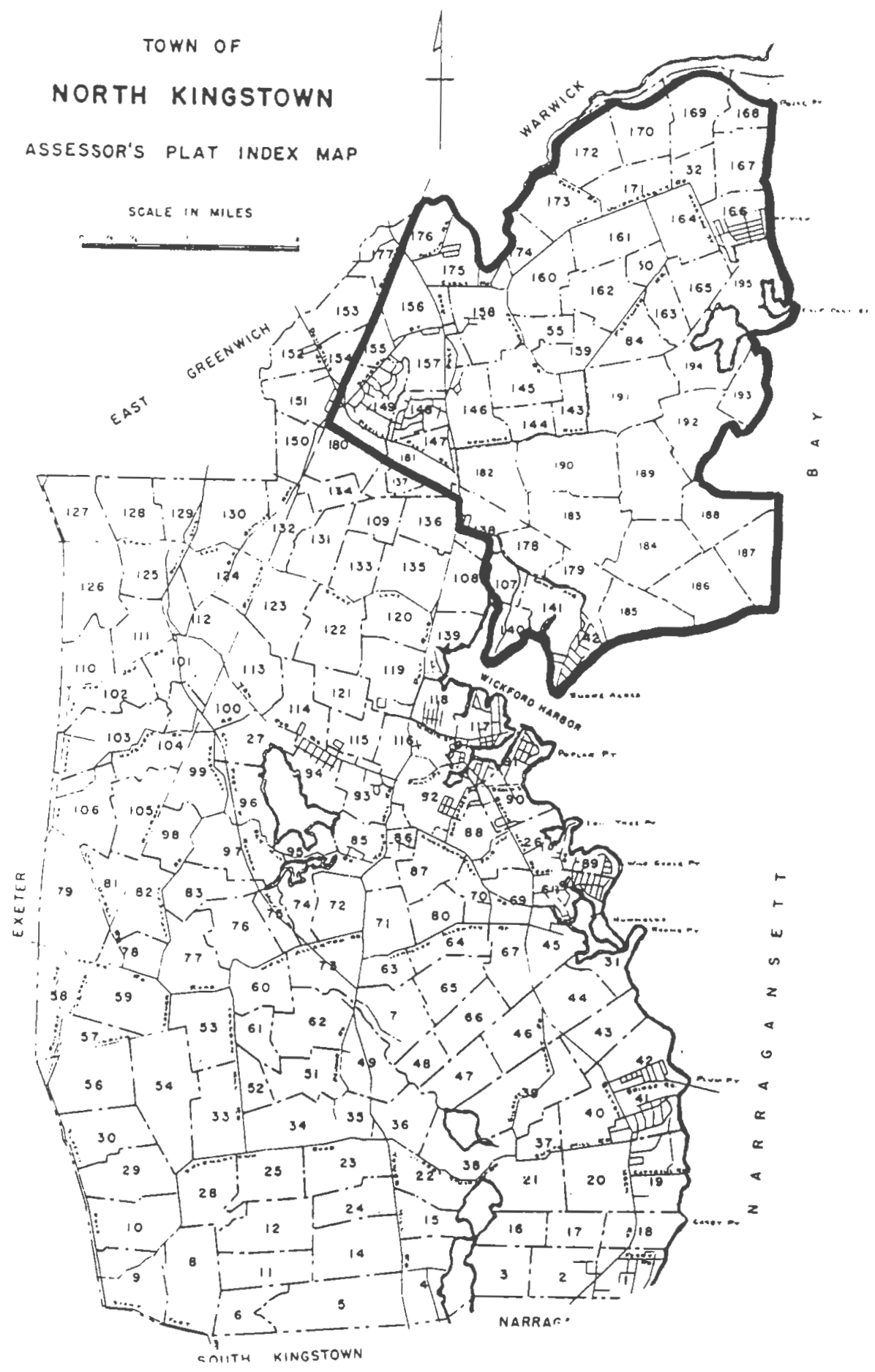

Figure 7.2 North Kingstown - Recommended Plat Map Notices Source of base map: North Kingstown Planning Department 
municipalities of the State outlining the powers they have to zone. An overlay district is defined by the Act as:

"a district established in a zoning ordinance that is superimposed on one or more districts or parts of districts and that imposes specified requirements in addition to, but not less than, those otherwise applicable for the underlying zone." (R.I.G.L. 45-24-31)

This definition demonstrates that the concept of an overlay zone is a legitinate and legal zoning tool.

An Airport Overlay District (AOD) is recommended for the study ared and is bounded primarily by the NEF $20-55 \mathrm{~L}_{3 n}$ contour line in North Kingstown and in Jamestown. However, in an effort to treat neighborhoods as single units, a residential area along the Post Road in North Kingstown is also included in the AOD. Within the airport overlay district are three different zones: B, C, and D. They are defined by the other contour lines and named according to the corresponding Land Use Guidance Zones discussed earlier. The land use controls applying to each AOD Zone are discussed separately. The overlay district as well as the plats recommended to have notices appear in Figure 7.3.

Zone B. According to the Land Use Guidance Chart in Appendix A that is published by the FAA, single-family residential is not an appropriate use in LUG Zone B. Any type of attached housing, where there are fewer exterior walls and more common walls, is acceptable. Given that most of the residential zoning in North Kingstown and all of the residential zones in Jamestown (within the study area) are for detached single family units, changing the zoning to attached housing is not a political reality. Although a very small portion of Zone C fies in 


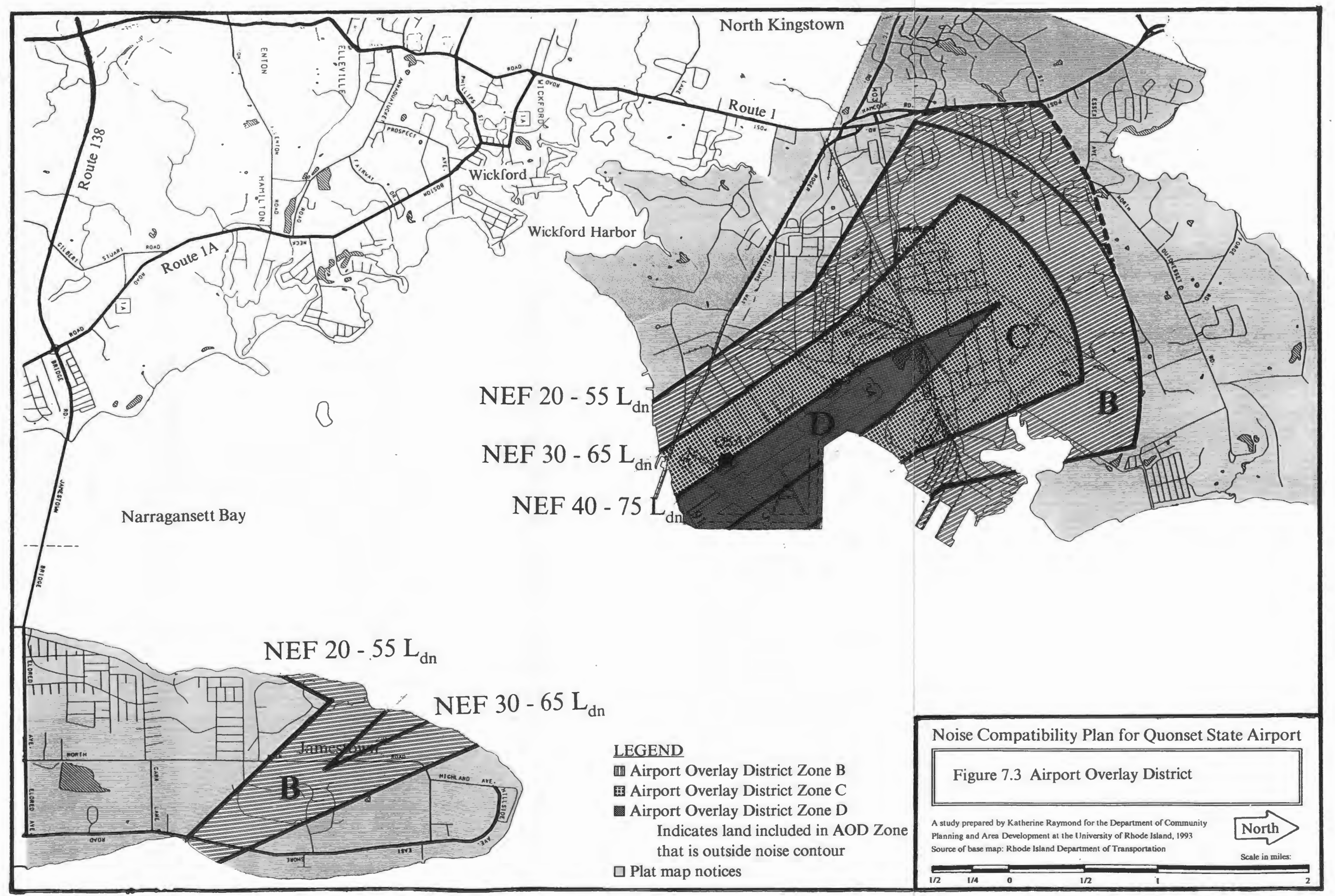


Jamestown, it is convenient and appropriate to include that small portion in Zone B.

The alternative to changing the zone is to adopt a stricter building code to achieve a greater sound reduction indoors. Typical additions to a building code include the following: thicker walls and insulation, double or triple pane windows, sound absorbing material in ventilating and air conditioning systems, caulking, and carpeting in bedrooms. The homeowner can even benefit from these requirements through lower heating costs. The code might also require air conditioning to minimize the need to open windows and prohibit fireplaces and through-door mailboxes. Soundproofing a home as it is built costs between four and ten percent of the total cost of the house. Soundproofing an existing home costs between 10 and 25 percent of the value of the house.

An additional requirement that the State should consider is a waiver signed by new land and home buyers that they are aware of the implications of residing near an airport. In addition, a restriction can be placed on the plat that noise easements must be granted to the State as a condition of purchasing the land or home.

Zone C. LUG Zone C is not suitable for residential development with the exception of high-rise apartment buildings. A zoning change is recommended for all residential zones in AOD Zone C, all of which are in North Kingstown. Current land use indicates that there are some undeveloped parcels of land that would be impacted by a zone change. A slight jog in the zone boundary is found in North Kingstown to include a portion of the Newcombe Road neigh borhood within the zone. As mentioned above, the small portion of Zone C in Jamestown should be treated as Zone B because it is so small. This area is suitable and desirable for office 
parks and corporate compounds if the infrastructure can support that, or agricultural and recreational if infrastructure is inadequate. It is also suitable for light industrial, but there is an over-abundance of industrial land already, and an office park type of development is more sympathetic to surrounding residential areas. All new structures should be designed to achieve a high reduction of interior noise.

Zone D. Fortunately, all of the land in this zone is industrial or open space. However, even in undeveloped industrial sites, there should be a building code in place that applies to office space and areas where the public is received to achieve a certain level of noise reduction indoors, depending on the nature of the activity. The land in this zone is either owned by the state or federal governments, so noise easements are not an issue.

\section{Phase II Recommendations - Mitigation Strategies}

Even if land use controls are implemented immediately, there will be existing homes and other non-compatible uses that will become subject to moderate to significant noise exposure in the future. There are three options available to address this potential problem, one of which is to do nothing. The other two options, compensatory and corrective both require large expenditures of funds. Compensatory methods do not correct the problem, i.e. reduce noise, but rather the airport owner pays the individual landowners in the community for the right to make noise. Corrective methods rectify the problem to a degree by reducing interior noise levels. The federal government contributes 90 percent of funds for noise abatement, so the State has to produce only 10 percent of project funds. These noise mitigation techniques 
are conceived with respect to the Airport Overlay District Zones. The appropriate time to implement any of these techniques is after noise exposure has achieved the predicted levels.

Zone B. Jamestown and North Kingstown both have a significant amount of residential land in Zone B, which is not considered to be compatible with noise exposure between NEF 20 and NEF $30\left(55-65 \mathrm{~L}_{\mathrm{dn}}\right)$. Because it would be cost prohibitive from the standpoint of both state and federal funding agencies, land and building purchase is beyond their means. Soundproofing, at 10 to 25 percent of building cost is also very expensive. The most cost effective way to mitigate noise in Zone B is through the condemnation and purchase of noise easements from all landowners where noise-sensitive activities are located.

Zone $C$. Because noise exposure is significant in this Zone, compensatory noise mitigation may not be adequate. The recommended action is for the State to soundproof all existing structures that contain noise-sensitive or incompatible uses. When neighborhoods are bisected by contour lines, it is desirable and equitable to maintain the neighborhood as a whole. For example, the Newcombe Road neighborhood in North Kingstown that falls into two zones should be treated as a single entity. Otherwise it is entirely possible for one home to be soundproofed while the home next door is not. As mentioned above, new development should be compatible with airport use. In the case of vacant or undeveloped land, the Town should purchase or transfer the development rights to another portion of the Town.

Zone D. Land in this severely impacted Zone is all owned by either local, state, or federal governments. Land uses there are compatible with the airport, however, it is possible that noise could become so annoying to people working in the buildings that some portions of 
these buildings should be soundproofed as well. Table 7.1 is a summary matrix of recommendations with respect to time and geographic area.

Table 7.1 Phase I and II Land Use Planning Recommendations

\begin{tabular}{|c|c|c|}
\hline Geographic Area & Phase I & Phase II \\
\hline $\begin{array}{c}\text { Towns of North Kingstown } \\
\text { and Jamestown }\end{array}$ & $\begin{array}{l}\text { full disclosure by } \\
\text { real estate agents }\end{array}$ & \\
\hline $\begin{array}{l}\text { Northeastern North } \\
\text { Kingstown and northern } \\
\text { Jamestown }\end{array}$ & plat map notices & \\
\hline $\begin{array}{l}\text { Overlay district } \\
\text { Zone B }\end{array}$ & $\begin{array}{l}\text { building code, waiver, } \\
\text { noise easement granted in new } \\
\text { home purchases }\end{array}$ & $\begin{array}{l}\text { noise easement purchased for } \\
\text { pre-existing homes }\end{array}$ \\
\hline $\begin{array}{l}\text { Overlay district } \\
\text { Zone C }\end{array}$ & $\begin{array}{l}\text { change residential zones } \\
\text { (e.g. office parks } \\
\text { or agricultural) }\end{array}$ & $\begin{array}{c}\text { soundproofing of pre-existing } \\
\text { homes, TDR and PDR of } \\
\text { undeveloped land }\end{array}$ \\
\hline $\begin{array}{l}\text { Overlay district } \\
\text { Zone D }\end{array}$ & $\begin{array}{l}\text { building code for offices and } \\
\text { public areas within industrial } \\
\text { buildings }\end{array}$ & $\begin{array}{l}\text { soundproofing pre-existing } \\
\text { offices and public areas } \\
\text { within industrial buildings }\end{array}$ \\
\hline
\end{tabular}

\section{Recommendations for Quonset State Airport}

The airport has already updated its standard operating procedures to include all practical ways of airport, aircraft, and airspace use that reduce noise. The military in particular has stringent and even self-imposed standards that are tailored to the characteristics of their specific aircraft. There are two areas in which this program could be improved in the future if compliance deteriorates. Increased knowledge and awareness among military and civilian pilots, and operators of transient aircraft is necessary because there is no enforcement 
mechanism. Ground operations, such as engine run-ups and maintenance, may become problematic depending on the types of new fixed base operators.

\section{Education Programs}

Military pilots attend annual seminars on aircraft safety that are also open to civilian pilots. A seminar similar to this or as a part of the safety seminar would educate all pilots about the importance of noise abatement. It is envisioned to be co-sponsored by either the FAA or the National Guard and the Rhode Island Airport Corporation. A periodic reminder or refresher course and update of regulations or policies may be the best way to gain cooperation from pilots.

A concise brochure or memorandum should be printed outlining the most important noise abatement strategies and distributed to transient pilots who make frequent nights to Quonset State Airport. A significant portion of transient military flights are transporting passengers destined for the Naval War College in Newport. ${ }^{2}$ It would make sense to distribute brochures to the War College for them to forward to visiting pilots.

\section{Ground Operations}

In addition to an increased number of flights causing overhead noise, there may be an increase in engine maintenance run-ups at the airport. The noise from an aircraft on the ground is quietest directly behind it, so aircraft should be facing Jamestown during engine testing. This would alleviate noise to the closest residential areas in North Kingstown. Performing 
maintenance indoors, either in hangars or "hush houses," is also a good solution.

\section{Conclusion and Issues for Further Study}

The noise compatibility program outlined here requires the early participation and initiative of the Towns of North Kingstown and Jamestown. These preliminary steps cost very little and will eventually save a lot of money. As someone once said, an ounce of prevention is worth a pound of cure. The Federal Aviation Administration has funds available for noise compatibility through the Airport Improvement Program.

Further study should include a cost-benefit analysis of the land use planning program implemented now as opposed to later or not at all. Noise contours should be verified through the FAA's Integrated Noise Model computer program and field checked with sound-measuring equipment. The Town of East Greenwich presents a challenging study because it is (or will be) exposed to noise from T.F. Green and Quonset. The projected increases in operations at Bradley International Airport should be of great concern not only to the future of Quonset, but also to T.F. Green. 


\section{Notes}

1. CLM/Systems, Inc., Airports and their environment: A guide to environmental planning, prepared for U.S. Department of Transportation, Office of the Secretary, Office of the Assistant Secretary for Environment and Urban Systems (1972): 179.

2. Air National Guard Operations. 


\section{APPENDIX A}

Land-Use Guidance Chart for Land-Use Noise Sensitivity Interpolation

\begin{tabular}{|c|c|c|}
\hline \multicolumn{2}{|r|}{ Land use } & \multirow{2}{*}{$\begin{array}{l}\text { Suggested } \\
\text { Land-use } \\
\text { guidance zone }\end{array}$} \\
\hline $\begin{array}{l}\text { SLUCM } \\
\text { No. }\end{array}$ & Name & \\
\hline 10 & Residential: & $A-B$ \\
\hline 11 & Household units & \\
\hline 11,11 & Single units, detached & $A$ \\
\hline 11,12 & Single units, semiattached & A \\
\hline 11,13 & Single units, attached row & B \\
\hline 11,21 & Two units, side by side & A \\
\hline 11,22 & Two units, one above the other & A \\
\hline 11,31 & Apartments, walk up & B \\
\hline 11,32 & Apartments, elevator & $\mathrm{B}-\mathrm{C}$ \\
\hline 12 & Group quarters & $A-B$ \\
\hline 13 & Residential hotels & B \\
\hline 14 & Mobile home parks or courts & A \\
\hline 15 & Transient lodgings & $\mathrm{C}$ \\
\hline 19 & Other residential & $A-C$ \\
\hline 20 & Manufacturing:* & $\mathrm{C}-\mathrm{D}$ \\
\hline 21 & $\begin{array}{l}\text { Food and kindred products, manufac- } \\
\text { turing }\end{array}$ & $C-D$ \\
\hline 22 & Textile mill products, manufacturing & $\mathrm{C}-\mathrm{D}$ \\
\hline 23 & $\begin{array}{l}\text { Apparel and other finished products } \\
\text { made from fabrics, leather, and } \\
\text { similar materials, manufacturing }\end{array}$ & $\mathrm{C}-\mathrm{D}$ \\
\hline 24 & $\begin{array}{l}\text { Lumber and wood products (except fur- } \\
\text { niture), manufacturing }\end{array}$ & $\mathrm{C}-\mathrm{D}$ \\
\hline 25 & Furniture and fixtures, manufacturing & $\mathrm{C}-\mathrm{D}$ \\
\hline 26 & $\begin{array}{l}\text { Paper and allied products, manufac- } \\
\text { turing }\end{array}$ & $\mathrm{C}-\mathrm{D}$ \\
\hline 27 & $\begin{array}{l}\text { Printing, publishing, and allied indus- } \\
\text { tries }\end{array}$ & $\mathrm{C}-\mathrm{D}$ \\
\hline 28 & $\begin{array}{l}\text { Chemicals and allied products, manu- } \\
\text { facturing }\end{array}$ & C-D \\
\hline 29 & $\begin{array}{l}\text { Petroleum refining and related indus- } \\
\text { tries }^{\dagger}\end{array}$ & C-D \\
\hline 30 & Manufacturing (continued): & \\
\hline 31 & $\begin{array}{l}\text { Rubber and miscellaneous plastic prod- } \\
\text { ucts, manufacturing }\end{array}$ & C-D \\
\hline 32 & $\begin{array}{l}\text { Stone, clay, and glass products, manu- } \\
\text { facturing }\end{array}$ & C-D \\
\hline 33 & Primary metal industries & $\mathrm{D}$ \\
\hline 34 & $\begin{array}{l}\text { Fabricated metal products, manufac- } \\
\text { turing }\end{array}$ & $\mathrm{D}$ \\
\hline 35 & $\begin{array}{l}\text { Professional, scientific, and controlling } \\
\text { instruments, photographic and opti- } \\
\text { cal goods; watches and clocks, } \\
\text { manufacturing }\end{array}$ & B \\
\hline 39 & Miscellaneous manufacturing & C-D \\
\hline
\end{tabular}


APPENDIX A

continued

\begin{tabular}{|c|c|c|}
\hline & Land use & Suggested \\
\hline $\begin{array}{l}\text { SLUCM } \\
\text { No. }\end{array}$ & Name & $\begin{array}{l}\text { Land-use } \\
\text { guidance zone }\end{array}$ \\
\hline 40 & $\begin{array}{l}\text { Transportation, communication, and utili- } \\
\text { ties: }\end{array}$ & \\
\hline 41 & $\begin{array}{l}\text { Railroad, rapid rail transit, and street } \\
\text { railway transportation }\end{array}$ & $\mathrm{D}$ \\
\hline 42 & Motor vehicle transportation & $\mathrm{D}$ \\
\hline 43 & Aircraft transportation & $\mathrm{D}$ \\
\hline 44 & Marine craft transportation & $\mathrm{D}$ \\
\hline 45 & Highway and street right-of-way & $\mathrm{D}$ \\
\hline 46 & Automobile parking & $\mathrm{D}$ \\
\hline 47 & Communication & $A-D$ \\
\hline 48 & Utilities & $\mathrm{D}$ \\
\hline 49 & $\begin{array}{l}\text { Other transportation, communication, } \\
\text { and utilities }\end{array}$ & $A-D$ \\
\hline 50 & Trade: ${ }^{t}$ & \\
\hline 51 & Wholesale trade & $\mathrm{C}-\mathrm{D}$ \\
\hline 52 & $\begin{array}{l}\text { Retail trade, building materials, hard- } \\
\text { ware, and farm equipment }\end{array}$ & $\mathrm{C}$ \\
\hline 53 & Retail trade, general merchandise & $\mathrm{C}$ \\
\hline 54 & Retail trade, food & C \\
\hline 55 & $\begin{array}{l}\text { Retail trade, automotive, marine craft, } \\
\text { aircraft, and accessories }\end{array}$ & $\mathrm{C}$ \\
\hline 56 & Retail trade, apparel and accessories & $\mathrm{C}$ \\
\hline 57 & $\begin{array}{l}\text { Retail trade, furniture, home furnish- } \\
\text { ings, and equipment }\end{array}$ & $\mathrm{C}$ \\
\hline 58 & Retail trade, eating and drinking & $\mathrm{C}-\mathrm{D}$ \\
\hline 59 & Other retail trade & \\
\hline 60 & Services: ${ }^{t}$ & \\
\hline 61 & $\begin{array}{l}\text { Finance, insurance, and real estate } \\
\text { services }\end{array}$ & B \\
\hline 62 & Personal services & $\mathrm{B}$ \\
\hline 63 & Business services & $\mathrm{B}$ \\
\hline 64 & Repair services & $\mathrm{C}$ \\
\hline 65 & Professional services & $\mathrm{B}-\mathrm{C}$ \\
\hline 66 & Contract construction services & $\mathrm{C}$ \\
\hline 67 & Governmental services & $\mathrm{B}$ \\
\hline 68 & Educational services & $A-B$ \\
\hline 69 & Miscellaneous services & $\mathrm{A}-\mathrm{C}$ \\
\hline 70 & Cultural, entertainment, and recreational: & \\
\hline 71 & $\begin{array}{l}\text { Cultural activities and nature exhibi- } \\
\text { tions }\end{array}$ & A \\
\hline 72 & Public assembly & A \\
\hline 73 & Amusements & C \\
\hline 74 & Recreational activities & $\mathrm{B}-\mathrm{C}$ \\
\hline 75 & Resorts and group camps & A \\
\hline
\end{tabular}


APPENDIX A

continued

\begin{tabular}{|c|c|c|}
\hline \multicolumn{2}{|r|}{ Land use } & \multirow{2}{*}{$\begin{array}{l}\text { Suggested } \\
\text { Land-use } \\
\text { guidance zone }\end{array}$} \\
\hline $\begin{array}{l}\text { SLUCM } \\
\text { No. }\end{array}$ & Name & \\
\hline 76 & Parks & $\mathrm{A}-\mathrm{C}$ \\
\hline 79 & $\begin{array}{l}\text { Other cultural, entertainment, and recre- } \\
\text { ational }\end{array}$ & $A-B$ \\
\hline 80 & Resource production and extraction: & \\
\hline 81 & Agriculture & $\mathrm{C}-\mathrm{D}$ \\
\hline 82 & Agricultural related activities & C $-D$ \\
\hline 83 & Forestry activities and related services & $\mathrm{D}$ \\
\hline 84 & Fishing activities and related services & $\mathrm{D}$ \\
\hline 85 & Mining activities and related services & $\mathrm{D}$ \\
\hline 89 & $\begin{array}{l}\text { Other resource production and extrac- } \\
\text { tion }\end{array}$ & $C-D$ \\
\hline 90 & Undeveloped land and water areas: & \\
\hline 91 & $\begin{array}{l}\text { Undeveloped and unused land area } \\
\text { (excluding noncommercial forest } \\
\text { development) }\end{array}$ & $\mathrm{D}$ \\
\hline 92 & Noncommercial forest development & $\mathrm{D}$ \\
\hline 93 & Water areas & $A-D$ \\
\hline 94 & Vacant floor area & $A-D$ \\
\hline 95 & Under construction & $A-D$ \\
\hline 99 & $\begin{array}{l}\text { Other undeveloped land and water } \\
\text { areas }\end{array}$ & $A-D$ \\
\hline
\end{tabular}

- Zone $C$ suggested maximum, except where exceeded by self-generated noise.

' Zone D for noise purposes; observe normal hazard precautions.

${ }^{t}$ If activity is not in substantial, air-conditioned building, go to next higher zone.

- Requirements likely to vary, individual appraisal recommended.

SOUHCE: Federal Aviation Administration [7].

Source: Horonjeff and McKelvey, Planning and design of airports, 1983, p. 583. 


\section{REFERENCES}

Arnoult, Malcolm D., Lynne G. Gillfillan, and James W. Voorhees. 1986. Annoyingness of aircraft noise in relation to cognitive activity. Perceptual and Motor Skills 63, 2: 599616.

Ashford, Norman and Paul H. Wright. 1992. Airport engineering, 3rd ed. New York: John Wiley and Sons, Inc.

Bolt Beranek and Newman, Inc. 1985. Task 2 data report, T.F. Green State Airport noise/and use project. Prepared for Rhode Island Department of Transportation and Federal Aviation Administration.

Bolt Beranek and Newman, Inc. 1979.. Noise control plan development. Seminar notes. Prepared for U.S. Department of Transportation, Federal Aviation Administration.

Broder, Ivy E. 1988. A study of the birth and death of a regulatory agenda. Evaluation Review 12, 3 (June): 291-309.

CLM/Systems, Inc. 1972. Airports and their environment: A guide to environmental planning. Prepared for U.S. Department of Transportation, Office of the Secretary, Office of the Assistant Secretary for Environment and Urban Systems.

Cohn, Louis F. and Roswell A. Harris. 1988. Improving public response to sensitive transportation projects. Journal of Transportation Engineering 114, 4 (July): 465-475.

Drollinger, Michael T. 1992. Land use planning approaches to mitigating general aviation aircraft noise. Transportation Research Record 1332: 11-20.

Fidell, Sanford and Laura Silvati. 1991. An assessment of the effect of residential acoustic insulation on prevalence of annoyance in an airport community. The Journal of the Acoustical Society of America 89, 1 (January): 224-247.

Harper, Donald V. 1988. Regulation of aircraft noise at major airports: Past, present, and future. Transportation Law Journal 17, 1: 117-166.

Harper, Donald V. 1988. The continuing dilemma of aircraft noise. Transportation Journal 28, 2 (Winter): $33-42$. 
Horonjeff, Robert, and Francis X. McKelvey. 1983. Planning and design of airports, 3rd ed. New York: McGraw-Hill Book Company.

Mead, Kenneth M. 1990. A viation noise: A national policy is needed. U.S. General Accounting Office, Resources, Community, and Economic Development Division.

National Industrial Pollution Control Council. 1972. Airports and the community. Sub-Council Report. Washington, D.C.: U.S. Government Printing Office.

Papsidero, Vince. 1992. Airport noise regulations. Planning Advisory Service 437: 1-15.

Rhode Island. 1956. Rhode Island general laws. Title I. Aeronautics (as amended through 1992).

Rhode Island Department of Administration, Division of Planning. 1987. Quonset State Airport master plan. Report Number 55.

Rhode Island Department of Transportation. 1983. T.F. Green State Airport noise compatibility program.

Rhode Island Department of Transportation. 1985. T.F. Green State Airport noise compatibility program.

Rhode Island Statewide Planning Program. 1972. Aircraft noise evaluation. Technical paper number 23 .

Rhode Island Statewide Planning Program. 1984. State airport system plan. Report Number 47. State Guide Plan Element 640.

Schlesinger, Gail. 1988. Airport noise: The proprieter's dilemma. Transportation Law Journal $16,2: 333-342$.

Schomer, Paul D. 1983. A survey of community attitudes towards noise near a general aviation airport. The Journal of the Acoustical Society of America 74, 6 (December): 1773-1781.

Schroeder, Walter K. 1980. Defenses of Narragansett Bay in World War II. East Greenwich: Rhode Island Publication Society.

Town of Jamestown. 1991. Jamestown comprehensive plan.

Town of North Kingstown. North Kingstown revised ordinances. Article V. Noise. 
Town of North Kingstown. 1992. North Kingstown comprehensive plan.

Transportation Research Board. 1990. Airport system capacity. Special report 226. Washington, D.C.: National Research Council.

U.S. Congress. House. Committee on Public Works and Transportation. 1990. Federal Aviation Noise Policy: Hearings before the Subcommittee on Aviation. 101st Cong., 2nd Sess., 25 September.

U.S. Congress. House. Committee on Government Operations. 1991. FAA and Airport Noise: Hearings before the Subcommittee on Government Activities and Transportation, 102nd Cong., 1st Sess., 24 June.

U.S. Department of Housing and Urban Development, Office of Metropolitan Planning and Development, Office of Planning Assistance and Standards, Environmental Planning Division. 1970. Airport environs: Land use controls.

U.S. Department of Transportation, Federal Aviation Administration. 1985 Minimum standards for commercial aeronautical activities on public airports. Advisory Circular. 150/5190-1A.

U.S. Department of Transportation, Federal Aviation Administration. 1990. Introduction to your airport. Washington, D.C.

U.S. Department of Transportation, Federal Aviation Administration. 1983. Noise control and compatibility planning for airports. Advisory Circular. 150/5020-1.

U.S. Department of Transportation, Federal Aviation Administration, Southern Region. 1991. Airport improvement program.

U.S. Department of Transportation, Federal Aviation Administration, Southern Region, Airports Division. Public's guide to federal environmental requirements and responsibilities.

U.S. Department of Transportation, Federal Aviation Administration, Office of Environmental Quality. 1977. Impact of noise on people. Washington, D.C.

U.S. Department of Transportation, Federal Aviation Administration. 1987. A model zoning ordinance to limit height of objects around airports. Advisory Circular. 150/5190-4A. 
U.S. Department of Transportation, Federal Aviation Administration. 1991. National plan of integrated airport systems 1990-1999. Washington, D.C.

U.S. Department of Transportation. Federal Aviation Administration. 1975. Citizen Participation in airport planning. Advisory Circular. 150/5050-4.

U.S. Department of Transportation, Federal Aviation Administration. 1978. Airport landscaping for noise control purposes. Advisory Circular. 150/5320-14.

Wiley, John R. 1986. Airport administration and management. Westport, Connecticut: Eno Foundation for Transportation.

Wright, Robert R. and Susan Webber Wright. 1985. Land use in a nutshell, 2nd ed. St. Paul: West Publishing Company. 